INTER NATIONAL MONETARY FUND
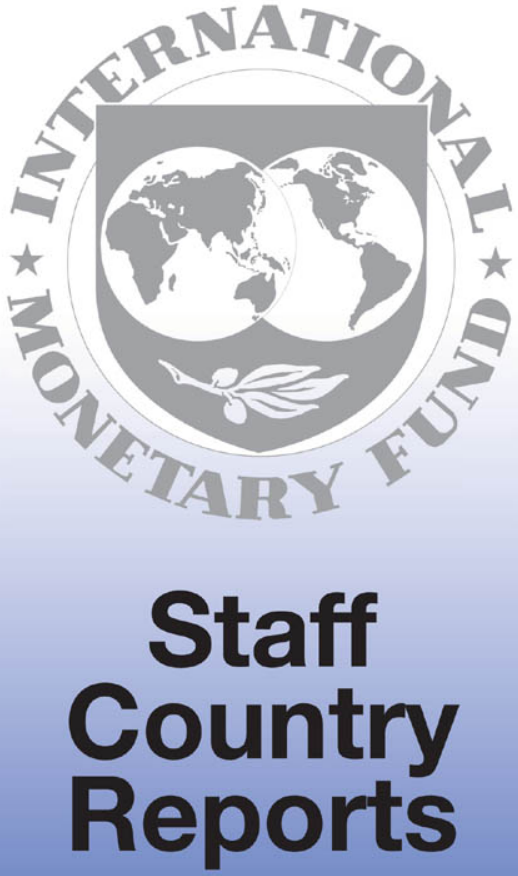


\section{Pakistan: Selected Issues and Statistical Appendix}

This Selected Issues and Statistical Appendix paper for Pakistan was prepared by a staff team of the Intemational Monetary Fund as background documentation for the periodic consultation with the member country. It is based on the information available at the time it was completed on October 21, 2002. The views expressed in this document are those of the staff team and do not necessarily reflect the views of the government of Pakistan or the Executive Board of the IMF.

The policy of publication of staff reports and other documents by the IMF allows for the deletion of market-sensitive information.

To assist the IMF in evaluating the publication policy, reader comments are invited and may be sent by e-mail to Publicationpolicy@imf.org.

Copies of this report are available to the public from

Intemational Monetary Fund • Publication Services

700 19th Street, N.W. - Washington, D.C. 20431

Telephone: (202) $6237430 \bullet$ Telefax: (202) 6237201

E-mail: publicatians@imf.org • Internet: http://www.imf.org

Price: $\$ 15.00$ a copy

\section{International Monetary Fund Washington, D.C.}




\section{INTERNATIONAL MONETARY FUND}

\section{PAKISTAN}

\section{Selected Issues and Statistical Appendix}

Prepared by Klaus Enders, Jean Le Dem, Hervé Joly, and Alina MElasiute (all MED); Axel Schimmelpfennig (FAD); and Yuri Sobolev (PDR)*

Approved by Pierre Dhonte

October 21, 2002

Contents

I. Overview.

II. Long Term Growth in Pakistan: Trends in Productivity and Factor Accumulation ......7

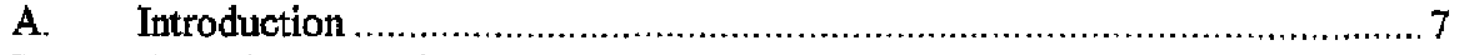

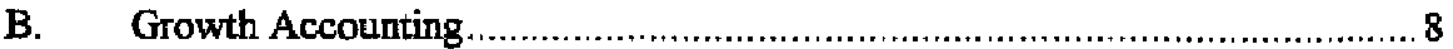

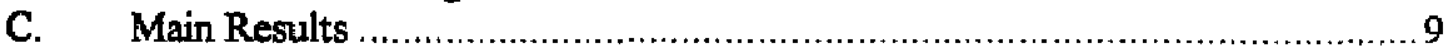

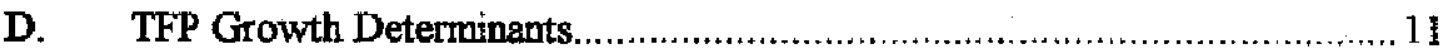

E. Pakistan's Growth Performance and Its "Social Gap" ...............................13

F. Medium-Term Growth Prospects .......................................................... 14

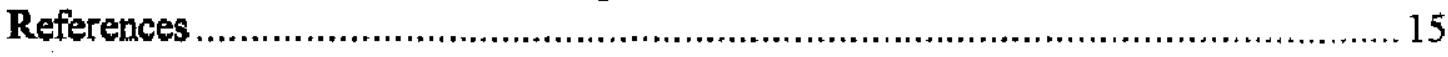

III. Poverty and Human Development .................................................................16

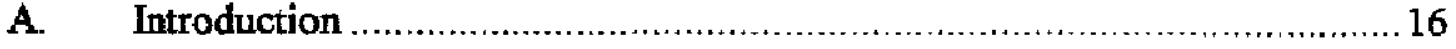

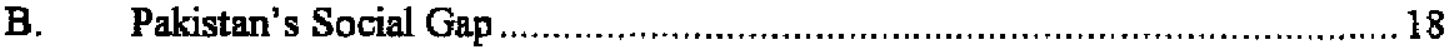

C. Exploring the Social Gap: the Human Development in

Pakistan in the 1990s

D. How Low Education and Health Affect Growth and Poverty ......................26

E. What Explains Education and Health Outcomes in Pakistan .........................29

F. Explaining the Social Gap: the Bias Against Social Spending …..................33

G. Quality of Public Social Spending ........................................................35

H. Pakistan's Devolution Reforms: Significance for Service Delivery .................38

I. Inducing Private Provision of Education and Health Services ......................40

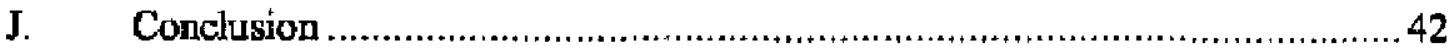

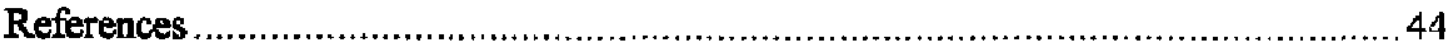

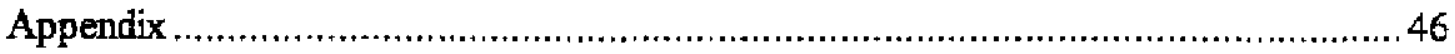

* Chapter III prepared by Tara Vishwanath and Ambar Narayan (World Bank). 
IV. Financial Sector Reforms in Pakistan............................................................. 47

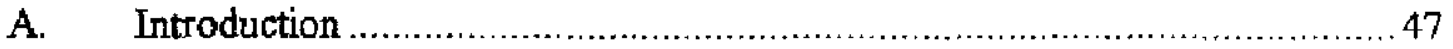

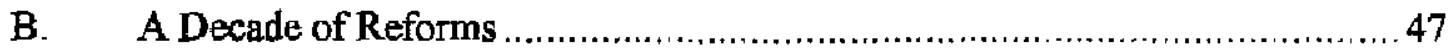

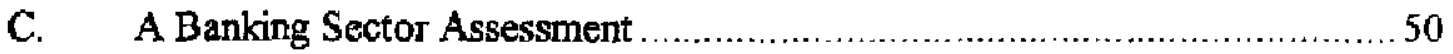

D. Banks' Limited Contribution to Financial Deepening in the 1990s .............53

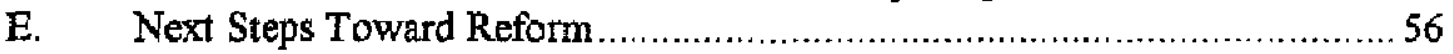

F. Recent Steps Toward the Development of Financial Institutions for the Poor .................................................................................. 59

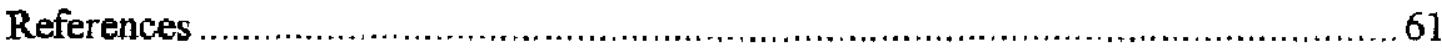

V. Draft Fiscal Responsibility and Debt Limitation Ordinance …..........................62

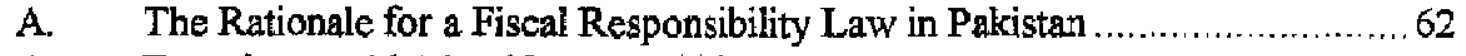

B. Experience with Fiscal Responsibility Laws ..........................................64

C. The Elements of Pakistan's Draft Fiscal Responsibility and Debt Limitation ......................................................................65

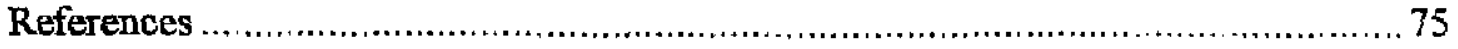

Text Boxes

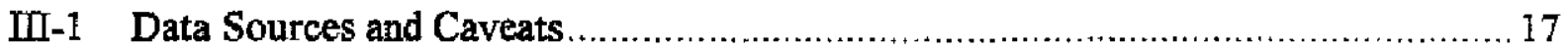

Text Tables

II-1. Real GDP, TFP, and Production Factor Growth, 1961-2001_........................... 10

II-2 Real Value Added By Sector, 1961-2000 ................................................ 10

III-1 Pakistan: Education, Health, and Demographic Indicators in Pakistan Relative to Comparable Countries.......................................................................... 19

III-2 Regional Comparisons of Select Human Development Indicators, 1998/99-1999/2000

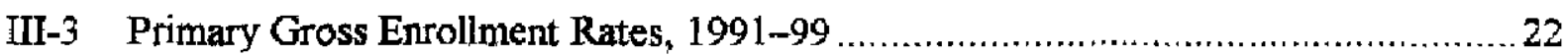

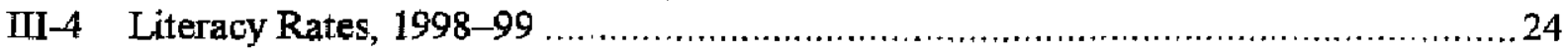

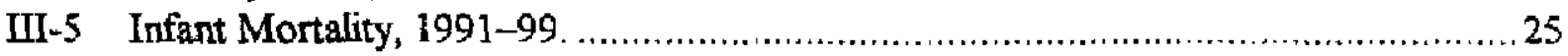

III-6 Benefit and Distribution of Public Spending in Education, 1998-99 _.................... 34

IV-1 Selected Financial Soundness Indicators: Banking Sector, 1990-2001 ................51

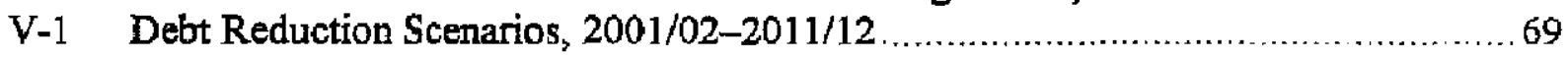

Figures

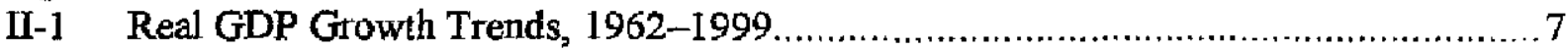

II-2 Actual and Trend TFP Growth for $\alpha=\beta=1 / 3,1962-2000 \ldots \ldots \ldots \ldots \ldots \ldots \ldots \ldots \ldots .9$

IJ-3 Trend GDP and Factor Input Growth Development ….................................... 9

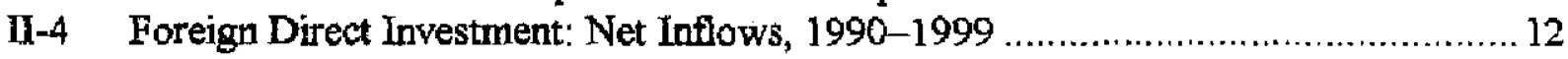

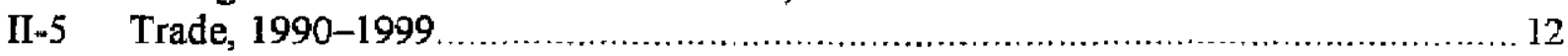

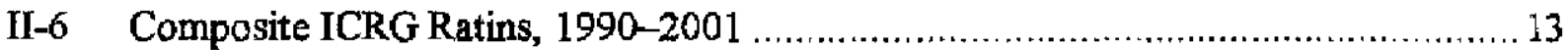

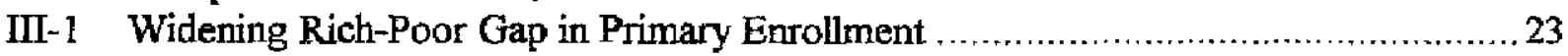

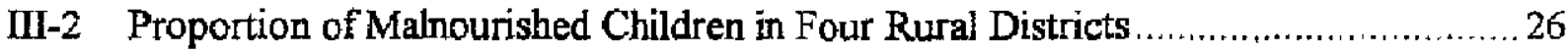

II-3 Student Attendance as a Function of Schod Quality. .......................................... 
III-4 Social Service Expenditures in Pakistan .......................................................... 33

IV-l Nonperforming and Default Loans as a Share of Total Gross Loans,

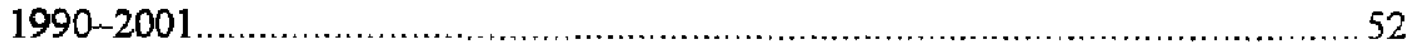

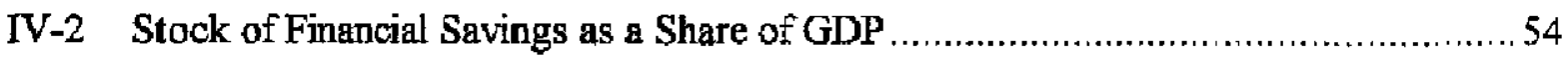

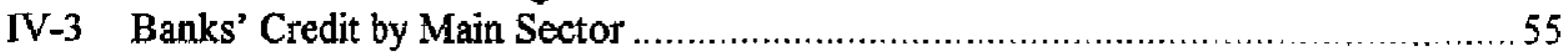

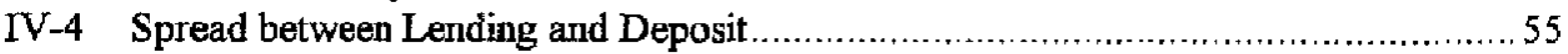

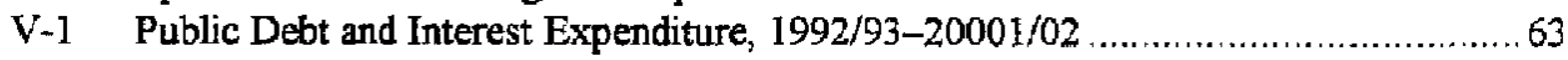

Statistical Appendix Tables

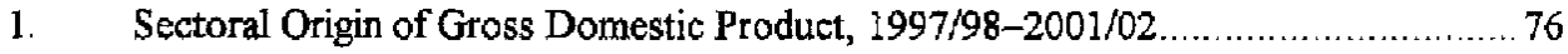

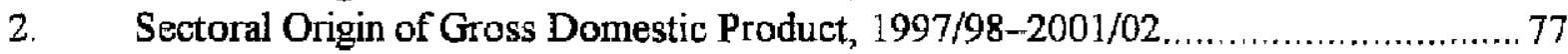

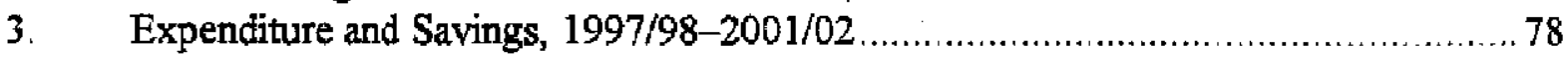

4. Gross Fixed Capital Formation by Economic Sector, 1997/98-2001/02 ................ 79

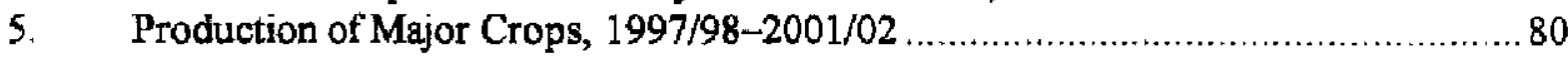

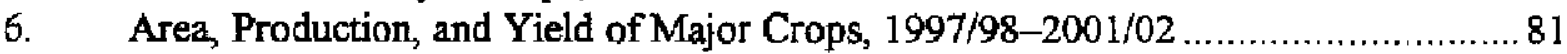

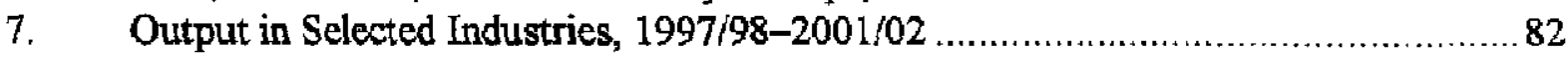

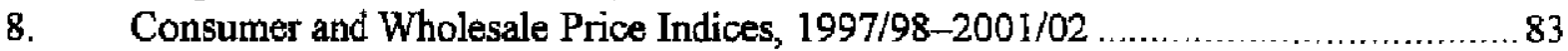

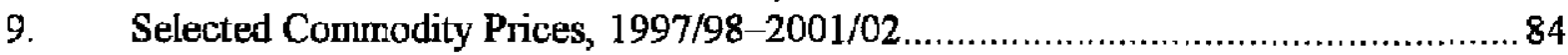

10. Increases in Procurement Prices of Selected Agricultural Commodities,

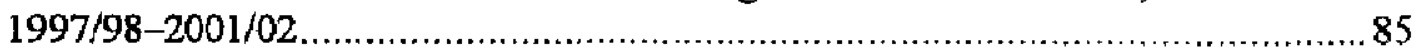

11. Domestic Retail Prices of Selected Petroleum Products, 1997/98-2001/02 _...........86

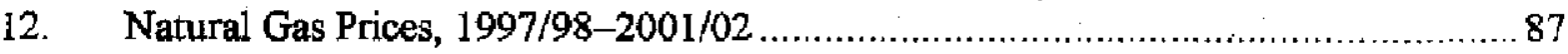

13. Summary of Consolidated Federal and Provincial Budgetary Operations,

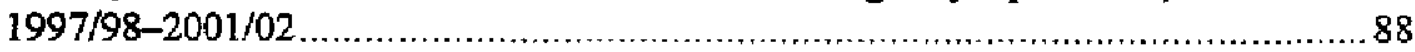

14. Consolidated Federal and Provincial Revenue, 1997/98 2001/02 _.....................89

15. Consolidated Federal and Provincial Expenditure, 1997/98-2001/02 _..................90

16. Federal Government Fiscal Operations, 1997/98-2001/02 ...............................91

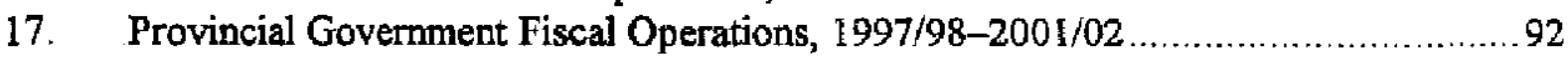

18. Social and Poverty Related Expenditure, 1997/98-2001/02 _............................ 93

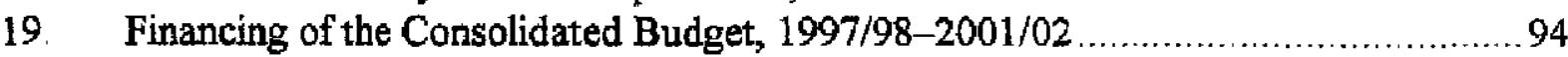

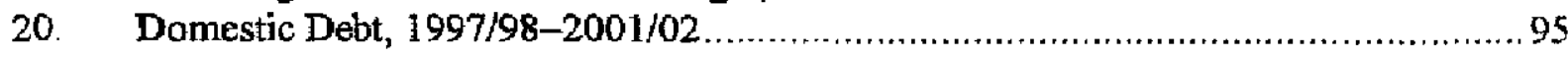

21. Accounts of the Water and Power Development Authority (Power Wing),

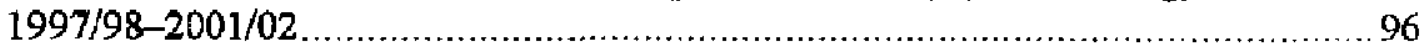

22. Accounts of the Karachi Electricity Supply Corporation, 1997/98-2001/02 _..........97

23. Accounts of the Pakistan Railways, 1997/98-2001/02 _.................................. 98

24. Accounts of the Pakistan International Airlines, 1999-2002 _............................. 99

25. Accounts of Pakistan Steel Mills, 1998/99-2001/02 ….............................. 100

26. Monetary Survey, 1997/98-2001/02 .................................................. 101

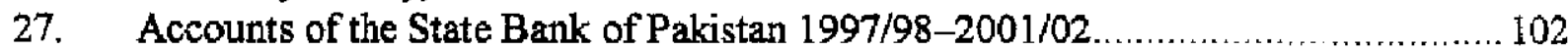

28. Accounts of the Scheduled Banks, 1997/98-2001/02 …............................... 103

29. Credit to the Economy, 1997/98-2001/02 …............................................. 104

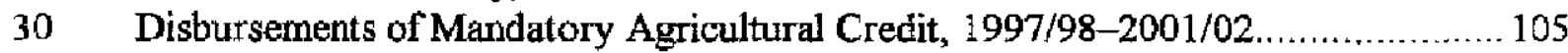

31. Market Share of Banks, 1997/98-2001/02 …........................................... 106 
32. Nonperforming Loans of Banks and Development Finance Institutions,

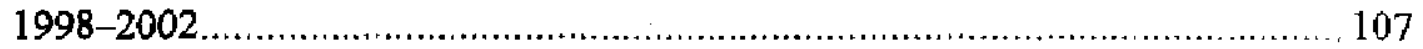

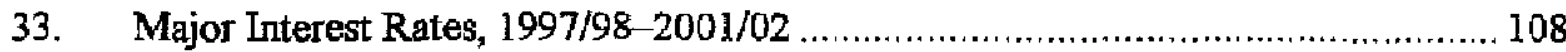

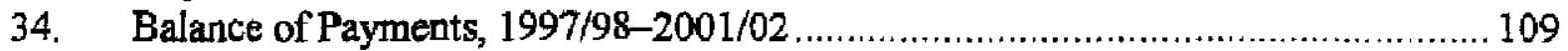

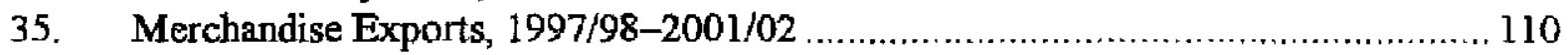

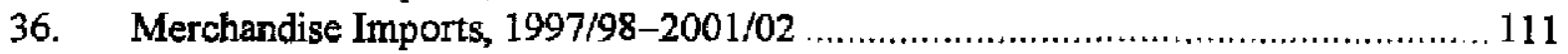

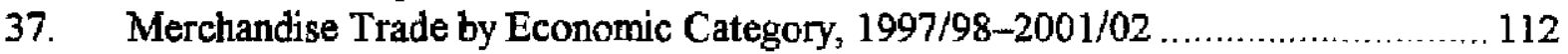

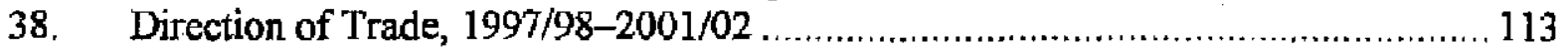

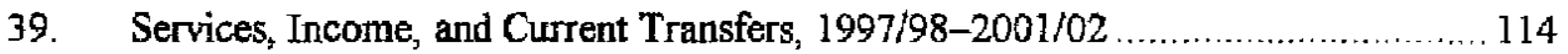

40. Home Remittances from Pakistani Nationals Abroad, 1997/98-2001/02 ............ 115

41. Medium- and Long- Term Capital Flows, 1997/98-2001/02 …...................116

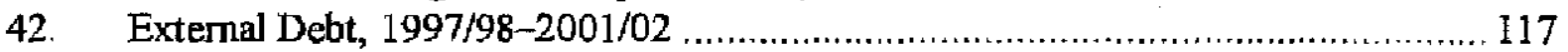

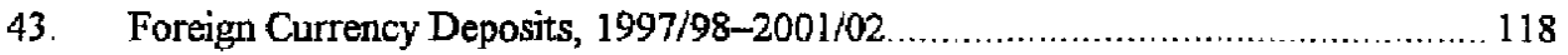

44. Summary of Public External Debt and Debt Service, 1997/98-2001/02 ............. 119

45. Public and Publicly Guaranteed Medium- and Long-Term Debt to Official Creditors, 1997/98-2001/02 …............................................. 120 


\section{OVRRVIEW}

1. The Pakistani government that took power in Oetober 1999 faced a difficult and deteriorating economic situation, including persistent high rates of poverty and low growth. Expansionary fiscal policies had saddled the country with a heavy public debt that constrained the investments in both physical and human capital needed to address Pakistan's lagging social indicators (its "social gap"). The external situation was highly vulnerable, and was managed through a complex web of exchange controls (including a freeze on foreign currency deposits in the banking system). Governance problems were pervasive, with Pakistan ranking as one of the most corrupt countries in the world.

2. The new government quickly launched a macroeconomic stabilization program, supported by a stand-by arrangement from the Fund. A first in Pakistan's recent history, all reviews under this arrangement were completed on time. While this program aiready included a substantive component of structural reforms, a more comprehensive medium-term strategy was elaborated during 2000/01 aimed at putting the economy on a sustainable highgrowth path while ensuring that growth would translate into meaningful improvements in living standards, including for the poor and most vuinerable. The strategy was detailed in an interim poverty reduction strategy paper ${ }^{1}$ endorsed by the Fund's and the World Bank's Boards in late 2001. The strategy is currently supported by various multilateral and bilateral institutions, including by the Fund through an arrangement under the Poverty and Reduction Growth Facility. The following notes look at some of the core issues of this strategy. As a new parliamentary government is about to assume its functions, it is hoped that the various notes could assist in identifying the key challenges ahead, in formulating policies that address the obstacles that stand in the way of high and equitable growth in Pakistan, and in explaining their rationale to a broader public

3. A central issue for Pakistan is a worrisome trend of declining growth. Chapter II looks at this trend from a growth-accounting point of view. While data weaknesses counsel a cautious interpretation of the results, the exercise does indicate that a combination of lower total factor productivity growth and declining investment in human and physical capital explains this growth outcome. While the causes of declining private investment rates are complex, and beyond the analysis of this paper, relevant factors likely inchude the uncertainties arising from a turbulent domestic and regional political environment, ${ }^{2}$ the "social gap", and the decline of public investment. The latter two are partly explained by the squeezing of fiscal space for human capital and infrastructure investments by high public debt service and defense outlays.

\footnotetext{
${ }^{1}$ See EBD/01/107.

${ }^{2}$ See SM/02/87.
} 
4. Chapter III provides considerable evidence that Pakistan's striking "social gap" in education and health is indeed a main culprit for a weakening growth performance. This section, beyond documenting the social gap, also looks at the underlying causes and identifies challenges in this area that need to be addressed, if Pakistan is to develop its human potential and reduce poverty and social vulnerability. To a large extent this task will fall to the local governments that were elected in 2001, but certain issues may require intervention by the central government.

\section{Chapter IV looks at the financial sector as another area that is central for} growth and governance, and where reforms are well advanced. The focus is on the banking system. A strong prudential framework is being put in place, and privatization of commercial banks is well underway. Better governance seems to have already curbed the growth in nonperforming loans, although working out the existing stock will require continued efforts. The main challenges for the future include the reform of nonbank financial institutions (insurance, pension funds, public development banks), as well as reform of the national saving schemes that continue to feature distortions that adversely affect financia] intermediation and imply high costs for the budget.

6. Finally, chapter $V$ adds to the current discussion in Pakistan on how to ensure a continuation of prudent fiscal policies that would reduce public debt to more substainable levels. The starting point is a draft fiscal responsibility law that was recently published for public comment. The law would codify recent gains in fiscal reporting and require the government to further improve on these gains. The law also contains a target to reduce public debt to 60 percent of GDP by 2011/12 as well as fiscal rules that ensure this debt recuction to be achieved in a balanced and orderly fashion. 


\section{Long Term Growth in Pakistan: Trends in Productivity and Factor ACCUMULATION ${ }^{3}$}

\section{A. Introduction}

7. From 1961 to 2001, Pakistan has always experienced positive real GDP growth. However, growth rates slowed from almost 7 percent in the 1960 s to about 3 percent in the 1990 s. In the regional context, Pakistan grew faster than South Asia by an average 2 percent through most of the $1960 \mathrm{~s}$ and 1970s, and at similar rates during the $1980 \mathrm{~s}$. However, since 1993 Pakistan's growth was below the regional average (Figure $\Pi-1$ ). ${ }^{4}$ More generally, trends in growth in Pakistan has been steadily slowing from initially very high levels since the 1960s, whereas growth in South Asia has been steadily accelerating for the four decades.

Figure II-1. Pakistan and South Asia: Real GDP Growth Trends, 1962-1999

(Three-year moving average, in percent)

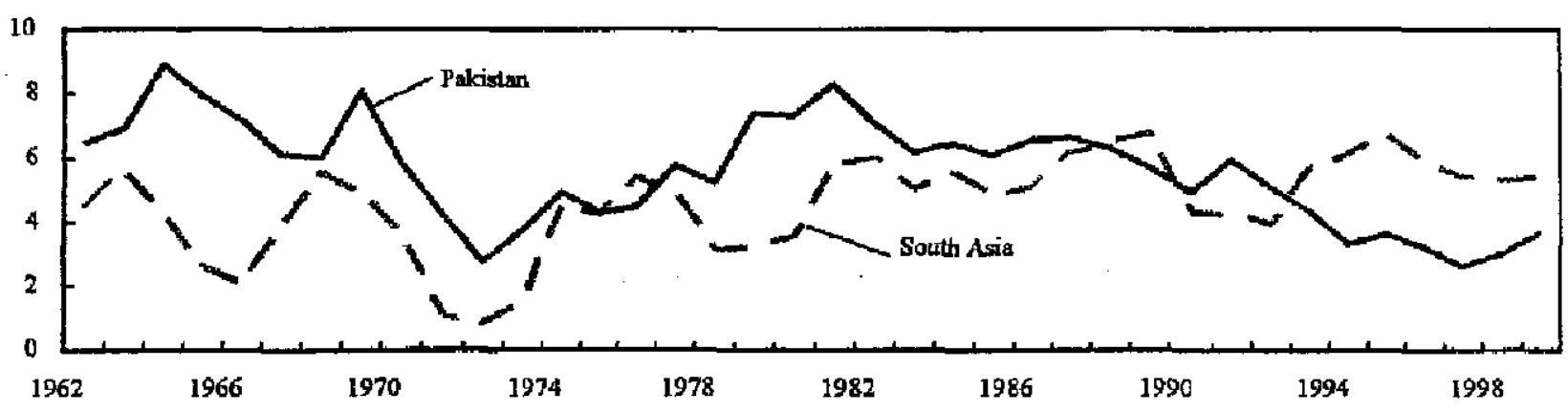

Sources: World Development Indicators (2002); and World Bank.

8. This paper is organized as follows. Section B breaks down Pakistan's growth trends into productivity and factor accumulation trends, using a standard growth accounting approach. Section $C$ discusses the results. Section D speculates about some of the factors that may explain Pakistan's total factor productivity (TFP) performance, Section E deals more specifically with the role of Pakistan's social gap. Section F reviews medium-term growth prospects in light of the preceding analysis.

\footnotetext{
${ }^{3}$ Prepared by Alina Milasiute (MED).

${ }^{4}$ Data for South Asia represent weighted averages of growth rates for Afghanistan, Bangladesh, Bhutan, India, Maldives, Nepal, Pakistan, and Sri Ianka.
} 


\section{B. Growth Accounting}

\section{Cobb-Douglas production function}

9. To analyze Pakistan's growth of aggregate ontput, a standard growth accounting exercise is used, assuming that national production can be modeled by using a Cobb-Douglas production function with constant returns to scale:

$$
Y=A K^{2} H^{\beta} L^{7-\alpha-\beta} \text {. }
$$

Here $Y$ denotes real gross domestic product, $A$-total factor productivity (TFP), $K$-real capital stock, $L$-labor force, and $H$-a human capital stock measure (it is assumed that $H=s L$, where $s$ represents average years of school of total population aged 25 and over, as estimated by Barro and Lee (2000). Due to the unavailability of a single data source for the whole period, a variety of sources was used. Estimates of real capital stock for 1960-1994 were obtained from the study by Bosworth and Collins (1995). For the later years, real capital stock was estimated using real gross capital formation and an assumed depreciation rate of 3 percent. Labor force time series were generated from databases from Bosworth and Collins, Intemational Labor Organization, and the World Economic Outlook. These data weaknesses imply that in this exercise only orders of magnitude, rather than exact estimates, should be considered as relevant. A further limitation of this approach is that it includes the large agricultural sector, which is significantly influenced by weather conditions. Thus, TFP fluctuations, especially in dealing with subperiods, may reflect variations in rainfall.

Equation (1) can be rearranged to:

$$
y=\{a+a k+\beta h+(1-a-\beta) l
$$

where the lowercase variables denote the growth rate of corresponding uppercase variables. GDP growth is thus broken down into TFP growth and a weighted average of the growth rates of production factors.

10. For the purposes of this stody equal factor shares $\alpha=\beta=(1-\alpha-\beta)=1 / 3$ are assumed. To assess the robustness of our results, TFP was also estimated using different factor share values. This did not significantly change the final results (see below).

\section{Trend GDP — adjusted TFP}

11. TFP growth estimates derived using actual GDP make it difficult to determine to what extent the TFP flnctuations are driven by short-term factors such as droughts or business cycles, as opposed to longer-term economic trends. To measure TFP growth adjusted to such cycles, trend GDP was estimated via a Hodrick-Prescott filter (HP filter), decomposing time series data into cyclical and growth components and interpreting the latter as trend GDP. Adjusted TFP growth was then calculated using trend GDP in Equation (2) (Figure II-2). 
Figure $\Pi-2$. Pakistan: Actual and Trend TFP Growth for $\alpha=\beta=1 / 3,1962-2000$

(Three-year moving average, percent)

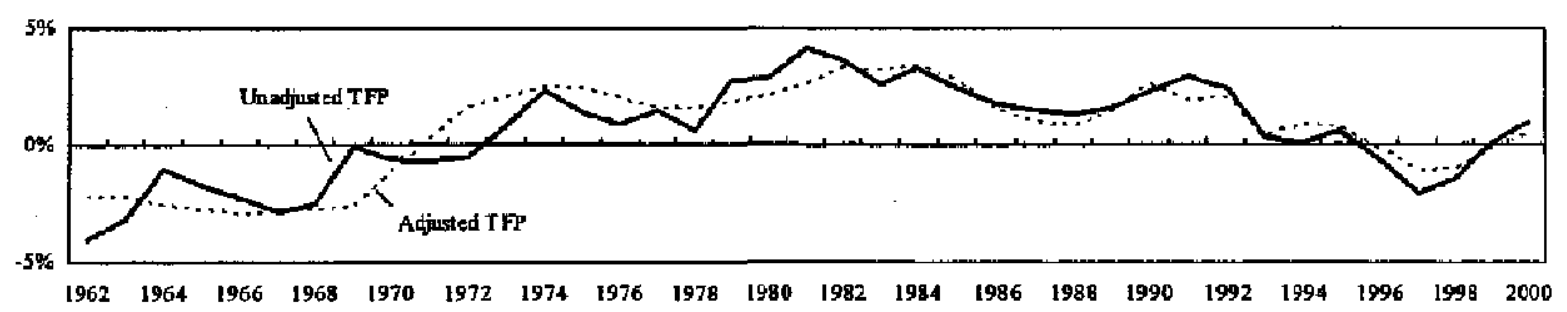

\section{Main Results}

12. Overall, for the 1961-2001 period, Pakistan has experienced moderate TFP growth (0.5 percent annually on average, whether measured by actual or by trend TFP), indicating that trend GDP growth of 5.6 percent over the period was driven mostly by factor accumulation, especially that of human and physical capital. In the 1960s, TFP experienced negative growth (on average -2.2 percent). In the $1970 \mathrm{~s}$, TFP growth became positive, peaking in the 1980 s (2.4 percent). This latter trend seems to have reversed in the second half of the 1990 s when TFP growth declined to -0.4 percent (Figure II-3, Table II-1).

Figure II-3. Trend GDP and Factor Input Growth Development

(Arithmetic average, in percent)

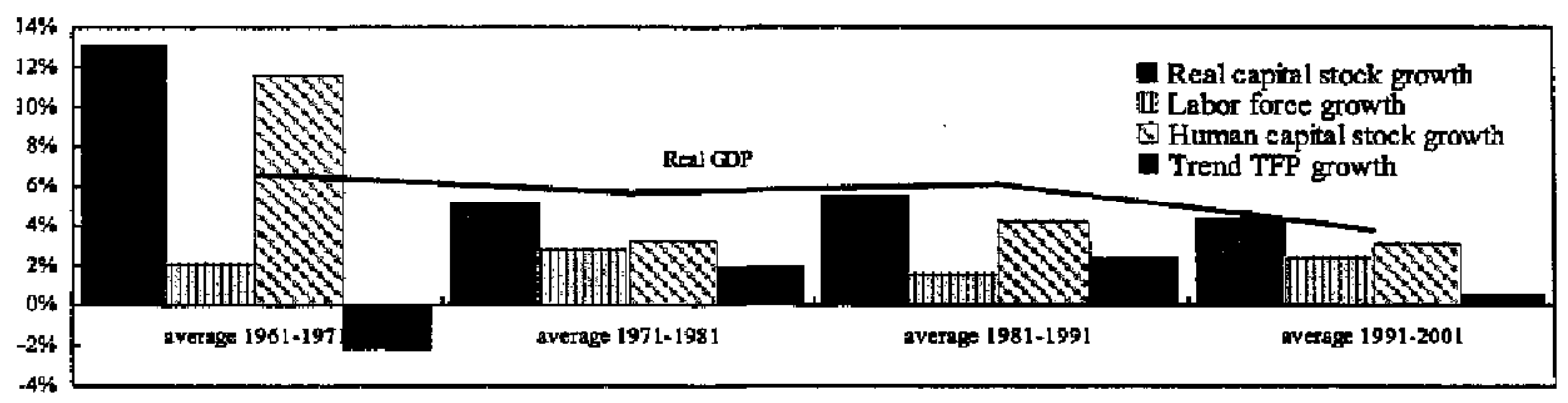

13. During the 1960s, Pakistan's strong growth performance was driven by real capital and human capital stock accumulation: the country experienced an average trend GDP growth of 6.7 percent with major advances in agricultural and large scale manufacturing sectors (Table II-2). After near-stagmation of agriculture in the $1950 \mathrm{~s}$, during the $1960 \mathrm{~s}$ the "Green Revolution" technology was introduced on a large scale. Industrial production was stimulated by import-substitution policies, encouraging private investment in this sector. The expansion of these two sectors was particularly capital intensive, resulting in an average 
physical capital stock growth rate of 13.1 percent per year. While the labor force grew by a modest 2 percent per year on average, levels of schooling improved significantly due to advances in basic education that resulted in an average human capital stock growth of 11.6 percent per year.

14. The 1970s witnessed a decline in growth rates of GDP and almost all factor inputs. The nationalization of industries and financial institutions in 1972, as well as surging oil prices may have contributed to the slowdown in the industrial sector. Similarly, difficulties related to land reforms, climate shocks, and a cotton virus depressed agricultural production. Physical capital stock accumulation slowed down to 5.2 percent per year. Although average annual labor force growth increased to 2.8 percent, human capital stock growth fell to 3.2 percent per year due to a quasi-stagnation in the average years of schooling for this period (it declined from 1.68 years in 1970 to 1.62 years in 1975 , increasing to 1.74 years in 1980). Trend GDP grew by 5.7 percent per year on average, owing to a much improved TFP growth performance.

Table II-1. Pakistan: Real GDP, TFP, and Production Factor Growth, 1961-2001

\begin{tabular}{lcccccc}
\hline & $1961-1971$ & $1971-1981$ & $1981-1991$ & $1991-2001$ & $1996-2001$ & $1961-2001$ \\
\hline & \multicolumn{7}{c}{ (Average annul growth rates) } \\
\hline Real Actual GDP & 6.6 & 5.0 & 6.2 & 3.9 & 3.2 & 5.4 \\
Real Trend GDP & 6.7 & 5.7 & 6.1 & 3.8 & 3.3 & 5.6 \\
Actual TFP & -2.2 & 1.3 & 2.5 & 0.6 & -0.5 & 0.4 \\
Trend TFP & -2.2 & 2.0 & 2.4 & 0.5 & -0.4 & 0.5 \\
Physical Capital Stock & 13.1 & 5.2 & 5.6 & 4.4 & 3.7 & 7.2 \\
Labor Force & 2.0 & 2.8 & 1.5 & 2.4 & 3.4 & 2.3 \\
Human Capital Proxy & 11.6 & 3.2 & 4.2 & 3.0 & 4.0 & 5.8 \\
\hline
\end{tabular}

Sources: Barro and Lee (2000); Bosworth and Colfins (1995); International Labor Organization; and Fund staff estimates.

Table II-2. Pakistan: Real Value Added By Sector, 1961-2000

1961-1971 1971-1981 1981-1991 1991-2001 1996-2001 1961-2001

\begin{tabular}{lrccccc}
\hline \multicolumn{7}{c}{ (Average annual growth rates) } \\
Agriculture & 4.3 & 3.1 & 4.8 & 4.5 & 4.9 & 4.3 \\
Industry & 10.1 & 5.6 & 6.8 & 4.1 & 2.2 & 6.2 \\
Manufacturing & 9.3 & 5.2 & 7.2 & 3.9 & 2.0 & 6.2 \\
Services & 6.4 & 6.1 & 6.6 & 4.6 & 4.0 & 6.0 \\
\hline
\end{tabular}

Sources: World Development Indicators (2002), World Bank. 
15. The lost growth momentum was partly recovered in the 1980s: average GDP growth of 6.1 percent was approaching the levels of the 1960s. Policies of deregulation and privatization may have contributed to improvements in private sector confidence and industrial sector performance. Agriculture showed an uneven performance during this period, experiencing negative growth during the first half of the decade. The average physical capital accumulation rate of 5.6 percent remained close to the level of the 1970s. Improvements in schooling led to an increase in human capital stock accumulation rate to 4.2 percent per year, despite a slowdown in labor force growth to 1.5 percent. Significant GDP growth with moderate production factor accumulation was made possible by a further improvement in TFP growth.

16. Economic growth decelerated again in the $1990 \mathrm{~s}$ with average trend GDP growth of 3.8 percent per year and stagnant TFP. During this decade the industrial sector, especially the textile industry, performed poorly; it might have been affected, inter alia, by prolonged political instability and inadequate infrastructure and power supply. AgriculturaI growth similarly slowed down mainly due to resource degradation. Physical capital stock growth decelerated somewhat, to average 4.4 percent. Human capital growth also decreased to 3 percent, despite the acceleration in labor force growth.

\section{TFP Growth Determinants}

17. To determine the exact reasons for the deterioration in Pakistan's TFP performance during the $1990 \mathrm{~s}$ is beyond the scope of this exercise. However, a number of factors are likely to have contributed to lower TFP growth, such as a decline in foreign direct investment (FDD, trade openness, and the quality of governance.

\section{Foreign direct investment}

\section{A number of studies have found that FDI can contribute to TFP growth. ${ }^{5}$ FDI} can facilitate technology transfer to developing countries from foreign to domestic firms, as well as better managerial and production practices in domestic firms. Pakistan has experienced declining FDI inflows since the mid-1990s (Figure II-4). FDI levels also trended lower in South Asia, but the trend was less pronounced than in Pakistan.

\footnotetext{
${ }^{5}$ Previous research on the effects of FDI on economic growth includes Borensztein et al (1998) and Blomstrom et al, (1992). Some examples of the effects of FDI on TFP are discussed in Eriesson and Irandoust (2001), De Mello, L. (1997), and Sadik and Bolbol (2001).
} 
Figure II-4. Foreign Direct Investment: Net Inflows, 1990-1999

(In percent of GDP three-year moving average)

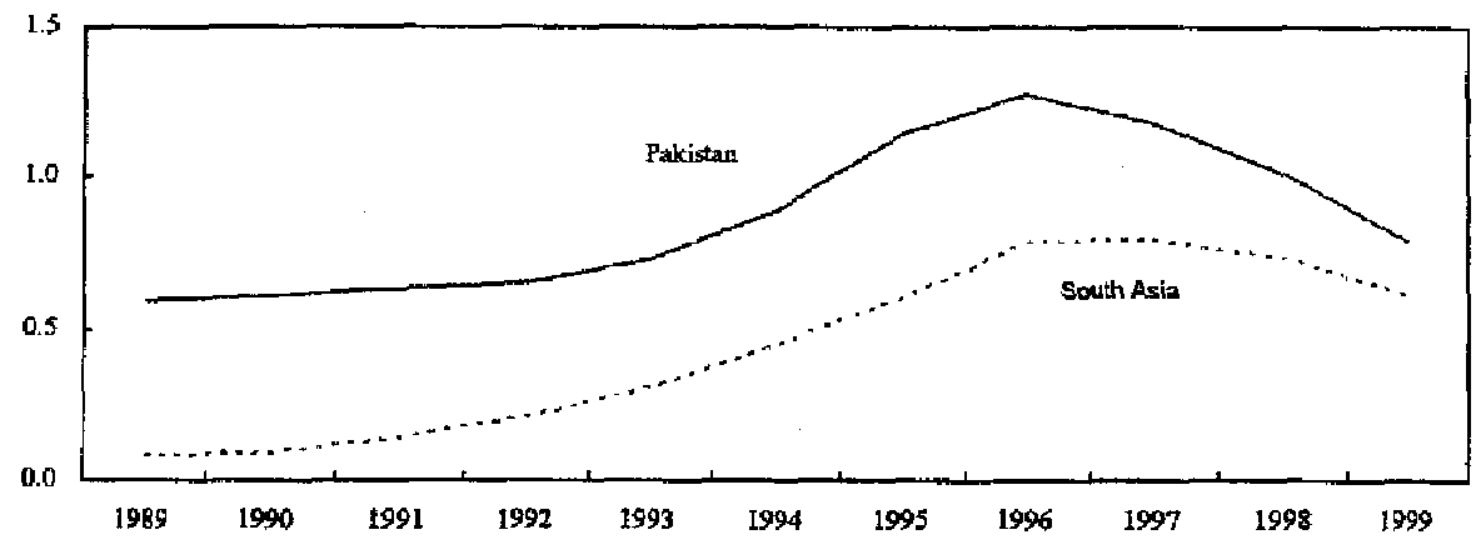

Source: World Development Indicators 2002, World Bank.

\section{Trade openness}

19. Higher trade openness may benefit TWP growth, for instance, through efficiency gains from specialization, by enlarging the interaction with modern economies, and raising the scope for learning-by-doing (further discussed in Miller and Mukti (2002)). Similarly to the developments in FDI, the evolution of Pakistan's trade openness, as measured by the GDP share of exports plus imports, compared unfavorably with that of the region overall, with a decline in the 1990s (Figure II-5). Trade openness in South Asia was increasing throughout the decade, albeit at a slower rate during the second half of the 1990s.

Figure I-5. Trade, 1990-1999

(In percent of GDP, three-year moving average)

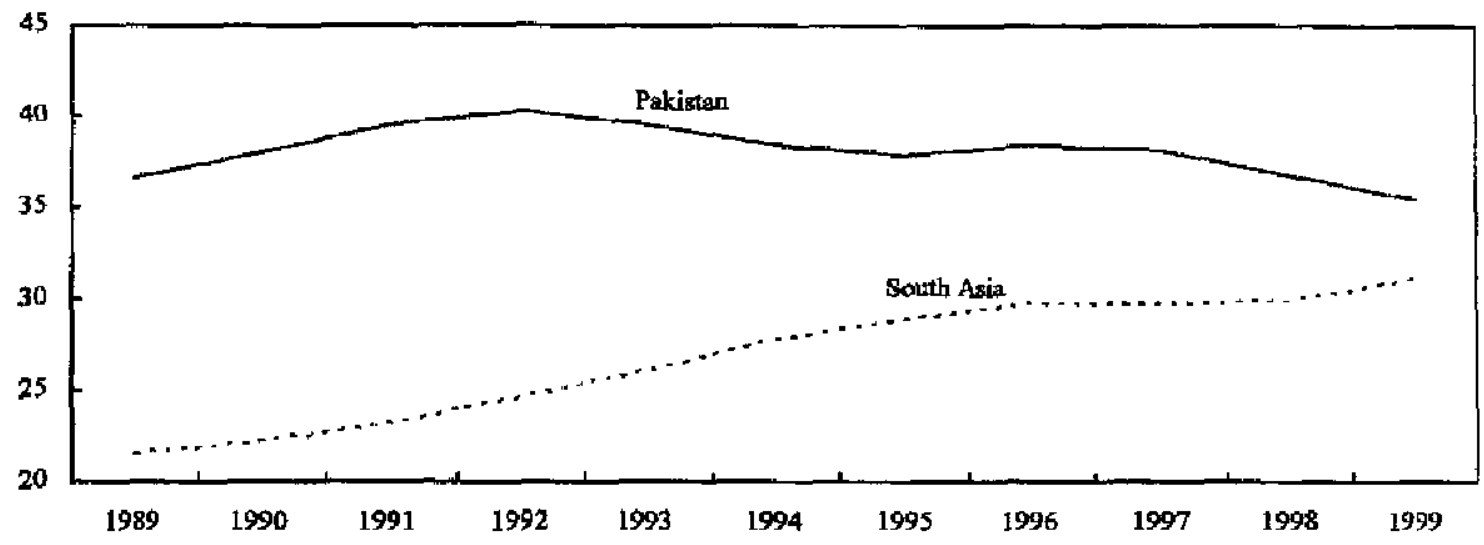

Source: World Development Indicators 2002, World Bank. 


\section{Quality of governance}

20. A number of studies have indicated that governance may be an important determinant of economic growth. Olson, Sarna, and Swamy (2000) use International Country Risk Guide Rankings (ICRG) as a proxy for quality of governance and show that productivity growth rates tend to be higher in better-governed countries. ${ }^{6}$ Composite ICRG ratings that include ratings for political, economic, and financial risk were consistently lower for Pakistan throughout the 1990s, peaking in August 1997 with 63 (moderate risk) and declining afterwards to 56 in March 2002 (high risk). South Asia, on the other hand, maintained its moderate risk ratings (Figure II-6). ${ }^{7}$

Figure II-6. Composite ICRG Ratings, 1990-2001

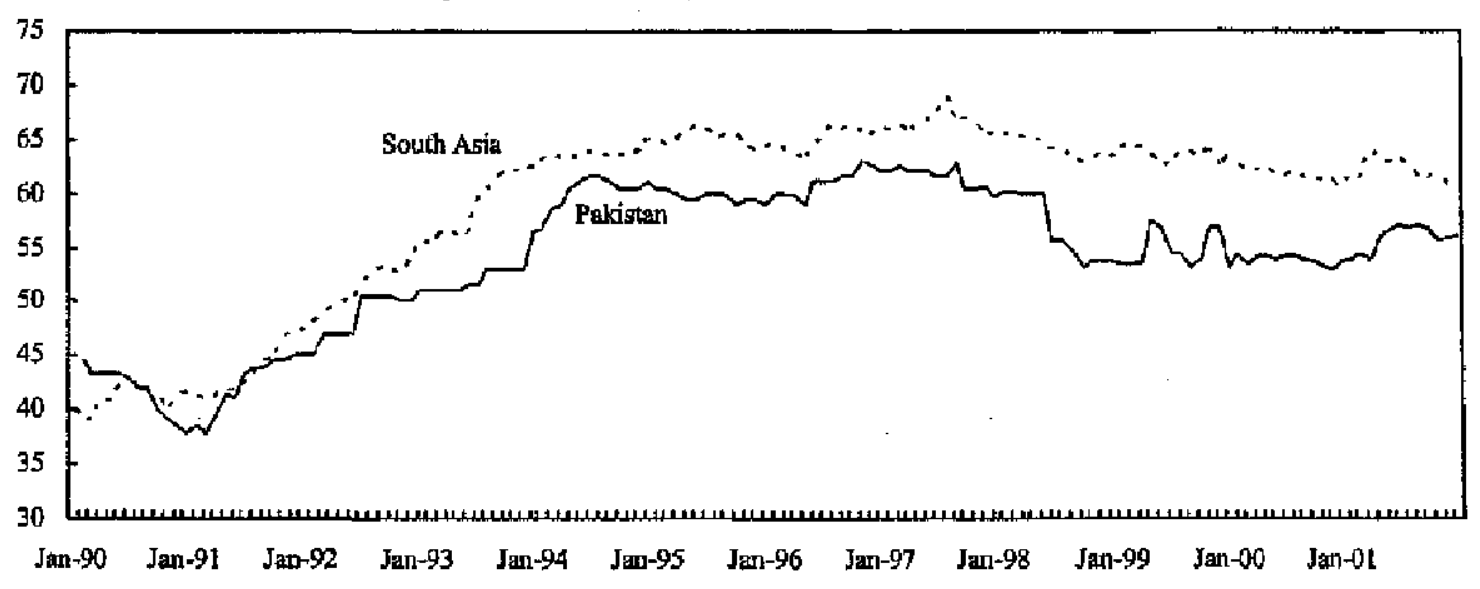

Source: International Country Risk Guide.

\section{E. Pakistan's Growth Performance and Its "Social Gap",}

21. The above analysis highlights the important role that weak growth of human and physical capital have played in reducing Pakistan's growth rate. To deternine why human and physical capital formation have slowed is beyond the scope of this section.

\footnotetext{
${ }^{6}$ The ICRG Risk Rating System assigns a numerical value (risk points) to a predeternined range of risk components according to a preset weighted scale for each country covered by the system. Each scale is designed to award the highest value to the lowest risk and the lowest value to the highest risk: very low risk (100-80), low risk (70-79.5), moderate risk (60-69.5), high risk (50-59.5), and very high risk (0-49.5).

${ }^{7}$ The ICRG ratings for South Asia are calculated as the arithmetic average of ICRG ratings for BangIadesh, India, Pakistan, and Sri Lanka.

${ }^{8}$ See Easterly (2001) for an approach along these lines.
} 
However, Chapter III explores in more detail to what extent Pakistan's comparatively poor health and education indicators, that is what has come to be calied Pakistan's "social gap", have contributed to low growth. Poor performance on human development will not only directly slow the growth of human capital, but will probably also lower the investment rate and TFP growth, for example by adversely affecting governance. Pakistan's growth slowdown may thus be in part attributable to its social gap, which has weakened its ability to take advantage of skill-based, technologically-driven changes in the world economy.

\section{F. Medium-Term Growth Prospects}

\section{Current mediam-term macroeconomic projections project an average annual} real GDP growth of 5 percent by $2003 / 04$. The above model and assumptions can be used to shed some light on medium-term growth prospects for Pakistan and the realism of these projections.

23. The attainability of this target depends on production factor and TFP growth rates. If their current growth rates would be raised to the average level of the period of 1961-2001, target real GDP growth can be achieved and even surpassed (Table II-7). If more recent trends were to continue, however, real GDP growth would be significantly lower: target GDP growth is not attainable if factor accumulation and TFP continue to grow at average 19912001 rates, and even less if their growth will remain at the 1996-2001 averages.

24. The "structural break" implied by the growth targets can also be highlighted by calculating the increase in the average growth rate of one factor necessary to achieve target growth while keeping other factor growth rates constant at 1991-2001 averages. In this case, the target GDP growth will be attained if, for example: (a) the real capital stock will grow at an average rate of 7.7 percent per year; (b) average labor force growth will be 5.6 percent; (c) average human capital stock growth rate will be 6.3 percent (equivalent to acheving three years of schooling by 2003 , compared with 2.45 years in 2000); or (d) average TFP growth will grow at 1.7 percent. 


\section{References}

Ahmed, S. M. and M. I. Ansari, 1998, "Financial Sector Development and Economic Growth: The South Asian Experience," Journal of Asian Economics, Vol. 9, No. 3, pp. 503-517.

Barro, Robert, and Jong-Wha Lee, 2000, "International Data on Educational Attainment: Updates and Implications," NBER Working Paper No. 7911 (Cambridge, Massachusetts: National Bureau of Economic Research).

Blomstrom, M., Lipsey, R., Zejan, M., 1992 "What Explains Developing Country Growth," NBER Working Paper No. 4681 (Cambridge, Massachusetts: National Bureau of Economic Research).

Borensztein, E., J. De Gregorio, and Jong-Wha Lee, 1998, "How Does Foreign Direct Investment Affect Economic Growth," Journal of International Economics, Vol 45, pp. $115-135$.

Bosworth, Barry, and Susan Collins, 1995, "Accounting for Differences in Economic Growth," Brookings Discussion Papers in International Economics, Brookings Institution, No. 115.

De Mello, L., 1997, "Foreign Direct Investment-Led Growth: Evidence From the Time Series and Pamel Data," Oxford Economic Papers, Vol. 51, No. 1, pp.133-151.

Ericsson, J., and M. Irandoust, 2001, "On the Causality Between Foreign Direct Investment and Output: A Comparative Study," The International Trade Journal, Vol.15, No.1, pp. 1-26.

Miller, Stephen M., and Mukti P. Upadhay, 2000, "The Effects of Openness, Trade Orientation, and Human Capital on Total Factor Productivity," Journal of Development Economics, Vol. 63, pp. 399-423.

Olson, M., N. Sama, and A.V. Swamy, 2000, "Governance and Growth : A Simple Hypothesis Explaining Cross-Country Differences in Productivity Growth," Public Choice, Vol. 102, pp. 341-364.

Sadik, Ali T. and Ali A. Bolbol, 2001, "Capital Flows, FDI, and Technology Spillovers: Evidence from Arab Countries," World Development, Vol. 29, No. 12, pp. 21112125.

Senhadji, Abdelhak, 2000,. "Sources of Economic Growth: An Extensive Growth Accounting Exercise," Staff Papers, Intemational Monetary Fund, Vol. 41, No. 1. 


\section{Poverty and Human Development ${ }^{9}$}

\section{A. Introduction}

25. Available data indicate that after significant poverty reduction during the 1980s, poverty in Pakistan stagnated in the 1990s, and continued to be marked by sharp differences across the country's provinces, and its rural and urban areas. In 1998-99, nearly 33 percent of the population could be classified as poor, indicating little progress since 199091 , when the proportion was 34 percent. $^{10}$

26. The slowdown in poverty reduction during the $1990 \mathrm{~s}$ was related to a significant drop in Pakistan's overall growth performance. The benefits of the growth that did occur were distributed unevenly: the rural-urban gap increased substantially between 1990-91 and 1998-99, due to rural poverty remaining stagnant while urban poverty declined. Inequality measures worsened for the country as a whole; and even in urban areas, where poverty declined on the whole, a sharp rise in inequality revealed an uneven pattern of growth and poverty reduction. This stagnating and uneven development is also mirrored by Pakistan's education and health indicators, which lag most other developing countries with comparable incomes (Pakistan's "social gap").

27. In addition, there exist in many instances significant social gaps within Pakistan, evident from disparities between men and women, among provinces, rural and urban areas, and most significantly, between rich and poor. Lagging national social indicators are in a large part a direct tesult of very low health and educational outcornes among the poorer segments of its population in comparison to its richer ones, whose indicators are in fact almost on par with those of developed countries. As argued here, these outcomes are in large part a result of failure of public services, on which the poor rely disproportionately since they, unlike the rich, are largely unable to resort to private service alternatives. The reliance of the rich on private alternatives has reduced pressure from the most politically influential segments of society to improve public service delivery-either in terms of influencing spending, or its quality and effectiveness.

\footnotetext{
${ }^{9}$ Prepared by Tara Vishwanath and Ambar Narayan of the South Asia Regional Office of the World Bank. The analysis of this note is based on World Bank (2002); unless otherwise indicated Details on the data sources and some related methodological issues and caveats are highlighted in Box III-1.

${ }^{10}$ See appendix, Trble A-1. For more details, refer to World Bank (2002), Chapter 2.
} 


\section{Box III-1. Data Sources and Caveats}

The main source for household data used in this chapter is the Pakistan Integrated Household Survey (PIHS) for the latest year available (1998-99). ${ }^{1 /}$ Designed to measure human development outcomes, the PIHS is representative at the national and regional (rural/urban) levels for all years. Moreover, the survey is representative at the level of incividual provinces and regions (rural/urban) within each province for all years excluding 1991. Some questions have been raised about the representativeness of the PIHS for specific areas like rural Sindh and Balochistan, and a careful study of survey methodology and field practices is in order to examine what improvements may be necessary to address any valid concerns. That said, the existing design of the PIHS does indicate it to be a largely reliable and representative source for human development outcomes at the national, provincial, and regional levels for Pakistan. An additional source for household data for this chapter is the Pakistan Rural Household Survey (PRHS, 2001)-conducted under the aegis of the Poverty Assessment for Pakistan - that is a resurvey of the panel survey conducted by the International Food Policy Research Institute during 1986-91 in four nura] districts of Pakistan. The PRHS sample has been expanded beyond the original panel of roughly 700 households, to around 2,800 households in 16 rural districts-making it representative for nural Pakistan,

In addition, the poverty trends reported in the Annex to the chapter are derived from the PIHS (1998-99) and the Household Income and Expenditure Surveys (HIES) for all previous years. The HIES--designed to measure household consumption and incomes only-were conducted independent of the PIHS until 1998-99, when the two were combined into a single integrated PIHS. There exists a high degree of comparability between PIHS 1998-99 and HIES for previous years, since the consumption questionnaires, sample sizes, and sampling methodologies are highly comparable for both the surveys. However, there are some caveats that must qualify the comparison of poverty estimates across surveys. ${ }^{2}$

- In the 1998-99 PIHS, many of the food items consumed by households are reported as fortnightly figures, unlike in previous surveys where monthly consumption figures were reported for all-this may affect the comparability of household consumption estimates.

$$
1
$$

- The average household sizes, particularly for households in the lowest expenditure categories, are higher in the 1998-99 PIHS compared with the HIES from 1992-93 to 1996-97. This difference-that may affect poverty trends-may be the result of differences in field techniques of data collection between the different surveys.

- For specific regions within provinces, estimating poverty trends may be problematic. For instance, poverty estimates for rural Balochistan in 1998-99 are low enough to be out of trend with those from previous years, and also seem inconsistent with other important indicators of well-being, where Balochistan scores well below the national averages. Poverty measurements for tural Balochistan are probably undermined by sampling errors, caused by the highly dispersed nature of the population, as well as nonsampling errors due to factors like seasonality in consumption.

1/ In some cases, for the sake of comparison over time, statistics are also reported from PIHS of previous years, namely $1991,1995-96$, and 1996-97.

2/ Details on these caveats on comparability of surveys across years and their implications can be found in the Annex to the Poverty Assessment for Pakistan (World Bank, 2002). 
28. Underlying the failure of public services in Pakistan is, firstly, a notable bias against social spending. During the past two decades, high military expenditures and a rising debt servicing burden have squeezed social expenditures. Second, the failure of public services can also be traced to a record of poor implementation of public programs, which has eroded their quality and impact. These patterns of spending can be attributed in part to skewed incentives confronting political decision makers in Pakistan.

29. Among the consequences of this are lagging human development indicators among a majority of Pakistan's population, which crucially undermines not only their well-being but also their productive capacity, with severe consequences for economic growth and poverty reduction. These findings highlight another important point: not only has economic growth failed to generate concomitant reductions in Pakistan's social gap, but the persistence of this gap is one of the likely reasons for Pakistan's low economic growth in the 1990s (see Chapter II). Part of a vicious circle of underdevelopment, Pakistan's social gap is a critical long-term constraint on sustainable growth and poverty alleviation.

\section{B. Pakistan's Social Gap}

30. Evidence indicates that while historically-particularly during the 1970s and the 1980 s-Pakistan's economic growth compared well with that of most developing countries, increasing incomes were not transiated into commensurate progress in human development, with the result that Pakistan has poor health, education, and fertility indicators for its level of per capita income. "1 Table III-1 shows the lag in health and education indicators in Pakistan. For instance, compared with what is expected for countries at this income level, Pakistan has 27 excess infant deaths per thousand, 23 percentage points less share of population with access to sanitation, and 42 percent lower health spending per capita. Further, Pakistan has 20 percentage points fewer of its elementary school age children enrolled in primary school--a gap explained entirely by the 40 percentage points fewer of elementary school age girls who attend primary school. Similarly, the 14 percentage point shortfall in secondary enrollment is explained mainly by a 20 point shortfall for females. An additional 24 percent of Pakistan's population is illiterate, above what is normal for a country of its income level. Public spending on education is 1.4 percentage points lower than the benchmark for income level.

\footnotetext{
"All estimations referred to in this section are from Easterly (2001). Most of the differentials described here remain significant if one controls for various regional effects, including a South Asia effect
} 
Table III-1. Pakistan: Education, Health, and Demographic Indicators in Pakistan Relative to Comparable Countries

(Regression coefficients, with t-statistics below each coefficient)

\begin{tabular}{|c|c|}
\hline Dependent Variable in each Regression & $\begin{array}{l}\text { Percentage Difference Between } \\
\text { Actual Indicator and Indicator } \\
\text { Pisdicted for Pakistan's income per capita 1/ }\end{array}$ \\
\hline Births attended by trained personnel, 1998 & $\begin{array}{r}-36.54 \\
-18.54\end{array}$ \\
\hline Pereent low birthweight, 1990s & $\begin{array}{l}11.63 \\
I 7.62\end{array}$ \\
\hline Log (health spending per capital PPP\$, 1990s) & $\begin{array}{l}-0.56 \\
-8.13\end{array}$ \\
\hline Public health spending as percent of GDP, 1996 & $\begin{array}{c}-162.00 \\
-7.38\end{array}$ \\
\hline Infant mortality, 1998 & $\begin{array}{l}27.43 \\
\text { J1.55 }\end{array}$ \\
\hline Under-five mortslity, 1998 & $\begin{array}{l}18.95 \\
3.91\end{array}$ \\
\hline Percentage of population with access to sanitation, $1990 \mathrm{~s}$ & $\begin{array}{l}-23.73 \\
-10.43 \\
\end{array}$ \\
\hline Rifal population & $\begin{array}{c}-25.07 \\
-8.86 \\
\end{array}$ \\
\hline Urban population & $\begin{array}{l}-17.23 \\
-7.33\end{array}$ \\
\hline Gross primary enrolment, $1990 \mathrm{~s}$ & $\begin{array}{l}-20.84 \\
-7.87\end{array}$ \\
\hline Female & $\begin{array}{l}-40.50 \\
-14.36\end{array}$ \\
\hline Male & $\begin{array}{l}-2.19^{*} \\
-0.84\end{array}$ \\
\hline Gross secondary enrollment, $1990 \mathrm{x}$ & $\begin{array}{l}-13.60 \\
-9.72\end{array}$ \\
\hline Female & $\begin{array}{r}-20.47 \\
-13.43\end{array}$ \\
\hline Male & $\begin{array}{l}-9.03 \\
-6.20\end{array}$ \\
\hline Illiteracy rate, $1990 \mathrm{~s}$ & $\begin{array}{l}24.42 \\
13.64\end{array}$ \\
\hline Fetmale & $\begin{array}{l}32.18 \\
15.73 \\
\end{array}$ \\
\hline Male & $\begin{array}{l}16.29 \\
10.30\end{array}$ \\
\hline Public spending on education, as percent of GDP, 1990s & $\begin{array}{l}-1.37 \\
-7.55\end{array}$ \\
\hline Population growth, 1997 & $\begin{array}{l}0.14^{*} \\
0.81\end{array}$ \\
\hline Contraceptive prevalence & $\begin{array}{l}-21.02 \\
-J 2.87\end{array}$ \\
\hline Fertility, 1998 & $\begin{array}{l}0.63 \\
6.83 \\
\end{array}$ \\
\hline Female proportion of population, 1999 & $\begin{array}{l}-2.06 \\
-21.30\end{array}$ \\
\hline
\end{tabular}

1/ The percentage is the coefficient on the Pakistan dummy variable in regressions of the dependent variable (health/education/ demographic indicatos) that also control for per capita incomes (PPP measure) over the relative time period. All coefficlents, except those marked with *, are statistically significant at the 5 percent level. 
31. In terms of demographic indicators, fertility in Pakistan is significantly higher than the average for comparator countries, and 21 percentage points fewer married women of childbearing age use contraceptives. Finally, there is the well-known phenomenon of "missing women." Pakistan has a lower female proportion of population than normal even by South Asian standards--presumably reflecting the consequences of various forms of gender discrimination. ${ }^{12}$ Girls between the ages of one and four had a 66 percent higher death rate than boys in Pakistan during the 1990s. ${ }^{13}$

32. The social gap for Pakistan has also persisted over time, even as economic growth occurred. Countries that grew at a rate comparable to Pakistan over the past two decades achieved greater improvements in social indicators. ${ }^{14}$ Infant mortality in the control group declined by 73 percent from 1960 to 1998 . In Pakistan, the same amount of growth resulted in a 43 percent lower decline. Also the difference between female and male illiteracy in Pakistan actually increased since 1970 as income per capita increased, while it declined sharply in the group of other countries.

33. Moreover, as Table III-2 shows, Pakistan's social development falls short not only of countries with similar incomes and growth patterns, but also of other countries in the region. School enrollment is less, adult illiteracy greater, and the infant and child mortality rates higher than in Bangladesh, India, and Sri Lanka.

34. The above tables conceal significant disparities among regions and rural and urban areas in Pakistan, which are in many instances at least as stark as the differences in performance between Pakistan and other developing countries. For instance, in the province of Sindh, only 25 percent of girls of primary age living in rural areas are enrolied in school, compared with 62 percent in urban areas. Similarly, while female literacy stands at only at 55 percent in urban Sindh, it reaches the low of 11 percent in rural North West Frontier Province (NWFP) and 7 percent in Balochistan. The next section will focus on highlighting such disparities along various dimensions, including gender and economic status.

\footnotetext{
${ }^{12}$ See World Bants (2001).

${ }^{13}$ Tinker (1998).

${ }^{14}$ See World Bank (2001) for details of the underlying exercise.
} 
Table III-2. Pakistan: Regional Comparisons of Select Human Development Indicators, 1998/99-1999/2000

\begin{tabular}{|c|c|c|c|c|c|c|}
\hline & \multicolumn{2}{|c|}{$\begin{array}{l}\text { Percent of children } \\
\text { (age 11-15) } \\
\text { currently enrolled in school* }\end{array}$} & \multicolumn{2}{|c|}{$\begin{array}{l}\text { Adult illiteracy } \\
\text { (age } 15+\text { ) } \\
1999 / 2000^{* *}\end{array}$} & \multicolumn{2}{|c|}{$\begin{array}{c}\text { Mortality rate per } 1000 \\
1998 / 99^{* *}\end{array}$} \\
\hline & Male & Female & Male & Female & Infant & Under-five \\
\hline $\begin{array}{l}\text { Bangladesh } \\
\text { India } \\
\text { Pakistan } \\
\text { Sri Lanka }\end{array}$ & $\begin{array}{l}62 \\
73 \\
63 \\
\cdots\end{array}$ & $\begin{array}{l}66 \\
58 \\
41 \\
\cdots\end{array}$ & $\begin{array}{c}48 \\
32 \\
42 \\
6\end{array}$ & $\begin{array}{l}70 \\
55 \\
73 \\
11\end{array}$ & $\begin{array}{l}73 \\
70 \\
83 \\
15\end{array}$ & $\begin{array}{c}96 \\
83 \\
116 \\
19\end{array}$ \\
\hline
\end{tabular}

Note: All Pakistan figures are for 1998-99 (Pakistan Integrated Household Survey: PIHS).

Sources for other countries: * Bangladesh: 1995-96 (HIES); India: 1995-96 NSO 52nd round; ** World Development Indicators

C. Exploring the Social Gap: the Human Development in Pakistan in the 1990s

\section{Edncation}

35. The PIHS data for education from the 1990s indicate that primary enrellment, as measured by the Gross Enrolment Rate (GER), showed some improvement for the country as a whole between 1991 and 1995-96, but none thereafter (Table III-3). The gains were essentially driven by higher enrollment rates of females, and in urban areas. ${ }^{15}$ School enroliments were relatively low among the poor, and the poor also had relatively higher dropout rates. Private schooling increased, though the exact ramifications for this remain unclear (see below).

\footnotetext{
${ }^{15}$ For urban males, primary GER increased from 86 percent to 95 percent; for urban fernales, the increase was from 77 percent to 88 percent.
} 
Table III-3. Paksitan: Primary Gross Enrollment Rates, 1991-99

(In percent)

\begin{tabular}{lcccc}
\hline & 1991 & $1995-96$ & $1996-97$ & $1998-99$ \\
\hline Punjab & & & & \\
Sindh & $\ldots$ & 73 & 73 & 76 \\
NWFP & $\ldots$ & 70 & 64 & 56 \\
Balochistan & $\ldots$ & 66 & 68 & 67 \\
Azad J \& & $\ldots$ & 63 & 58 & 58 \\
Northem Areas & $\ldots$ & $\ldots$ & $\ldots$ & 101 \\
Urbar & $\ldots$ & $\ldots$ & $\ldots$ & 75 \\
Rural & 81 & 88 & 87 & 91 \\
Male & 59 & 64 & 63 & 61 \\
Fenrale & 78 & 81 & 78 & 78 \\
Overall & 53 & 60 & 61 & 60 \\
& 65 & 71 & 70 & 69 \\
\hline
\end{tabular}

Source: PIHS for relevant years

\section{Gross educational enrollment figures are but one indicator of educational} achievement, and a more detailed picture emerges from looking at indicators like dropout and completion rates. These rates reveal that a large number of Pakistani children appear to enter school later than they should, and that few of those enrolled in school attend a grade that is appropriate for their age. Nationwide, 38 percent of those between age 5 and 17 have never attended school, and only 18 percent attend grades appropriate for their age. 41 percent of those who enter school drop out by the time they reach the age of 13 . Significant ruralurban gaps exist for these indicators also: as a proportion of those who have attended school, dropout rates are relatively higher in rural areas.

37. Both male and female literacy rates increased from 1991 to 1998-99, rising from 40 percent to 58 percent for males, and from 17 percent to 27 percent for females, with most provinces showing significant improvements. A comparison across provinces however reveals large differences, mirroring those observed for enrollment rates.

38. Educational attainment is closely related to poverty. As Figure III-1 shows, improvements in enrollment during the decade occurred primarily among those who were relatively well-off. Also, the proportion of children who have never attended school is much larger among the poor ( 52 percent) than among the nonpoor ( 31 percent). Poor children are also likely to fare poorly in school, with relatively higher dropout rates, and greater proportions attending grades lower than those appropriate for their age. The gap between the rich and the poor is reflected not only in the enrollment rates, but also in the pattern of spending on education. Households who are better off on average spend more on primary schooling per school-going child. 


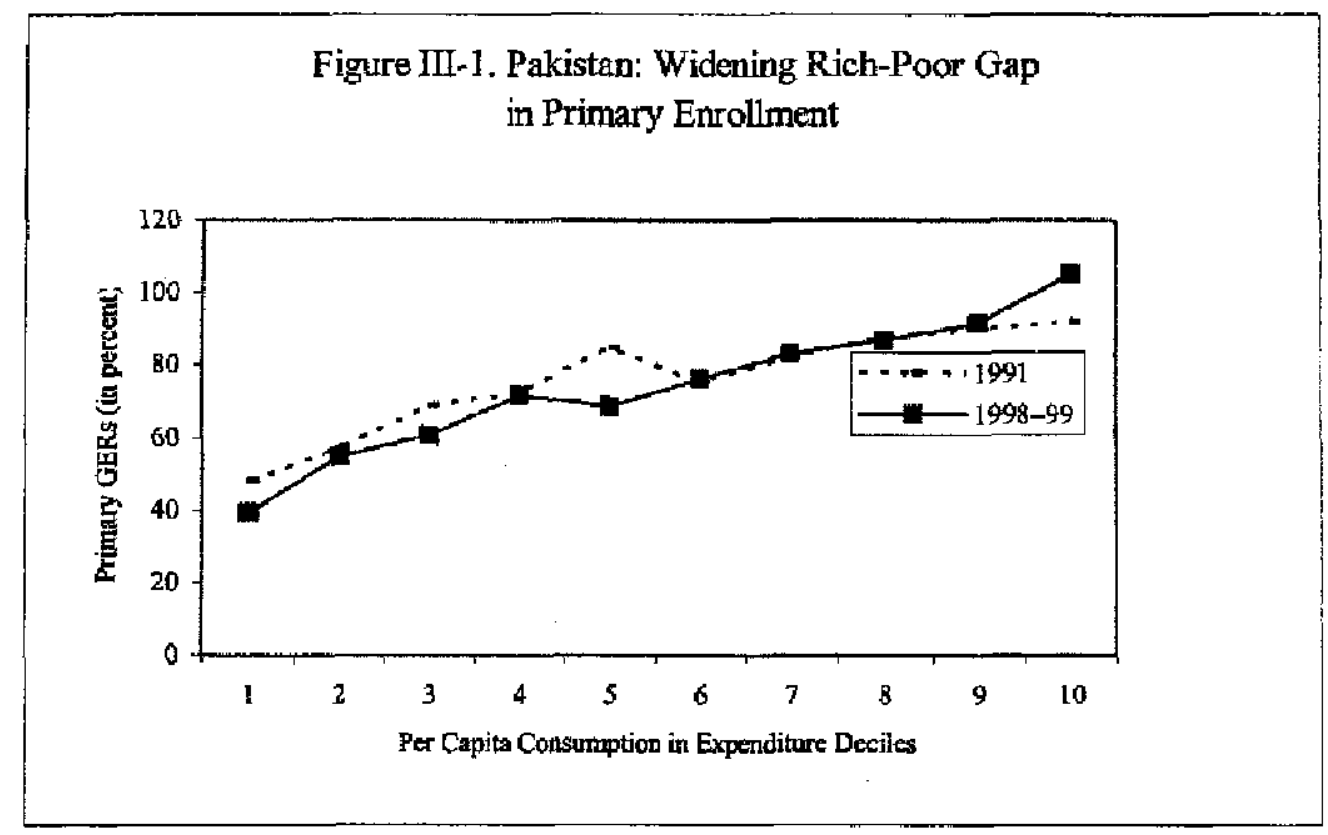

39. A multivariate regression analysis of the factors that affect school participation confirms that economic status, along with other factors like parents' education and access to school facilities, are critical in determining whether a child attends school. ${ }^{16}$ For example, nationally, the probability of a child attending school is 10 percent, 16 percent, 21 percent, and 25 percent higher if his/her bousehold belongs to the $2^{\text {nd }}, 3^{\text {rd }}, 4^{\text {th }}$ and $5^{\text {th }}$ expenditure 1 quintiles, respectively, rather than the 1st.

\section{Historically, Pakistan has had some of the lowest female enrollment rates in the} world. This is particularly troubling because numerous studies have documented the important role of female education, in the context of the variety of social and economic roles women typically play. While the gender gap in primary enrollment in Pakistan has been reduced to some extent over the last decade, significant gaps still remain, especially in rural areas (Table III-3). The same applies to literacy rates-female literacy rate is merely onethird of that among males in rural areas (Table III-4). School dropout rates are also higher for gir's than for boys, with the gap being relatively large for rural areas. There is also a sizeable male-female gap in household spending per student that persists across nearly all expenditure groups - indicative of bias in household behavior that is likely to further reinforce gender gaps in educational attainment.

\footnotetext{
${ }^{16}$ For details, see World Bank (2002). The results on what factors determine school participation are based on a probit regression of school participation of children of age 6 to 14 on a range of variables that are likely to explain the probability of participation. The variables include anes that reflect economic status of households (by consumption expenditure), land holdings, child's age, parents' education levels, household demographics, and for nural children, commmity characteristics including distance to nearest school and other forms of infrastructure.
} 
Table III-4. Pakistan: Literacy Rates, 1998-99

(In percent)

\begin{tabular}{llll}
\hline & Male & Female & Overall \\
\hline Urban & 73.2 & 52.3 & 63.1 \\
Rural & 51.0 & 16.8 & 33.6 \\
Overall & 58.0 & 27.2 & 42.5 \\
\hline
\end{tabular}

41. Another important educational trend in Pakistan is an observed increase in the share of the private sector in schooling over the years, to the extent that it is clearly no longer an elite phenomenon. Private share in primary enrollment (excluding enrollment in religious schools or madrassas) ${ }^{17}$ increased across all deciles, from 14 percent to 23 percent between 1991 and 1998-99, and in secondary enrollment from 8 percent to 17 percent. The increases were distributed across the economic spectrum, though most pronounced in the higher expenditure groups. According to a recent Census of Private Schools (2000), Pakistan has as many as 40,000 private schools, the result of significant growth over the 1990s.

\section{Health}

42. While various health indicators in Pakistan have shown improvements since the beginning of the decade, most indieators still compare inadequately with countries with similar levels of income. Overall, health indicators for Pakistan tend to be much worse in rural areas than in urban areas, and for the poor relative to those better off; they also tend to improve with women's education and where relevant, with access to safe water and sanitation.

43. On infant mortality, Pakistan's rate of 83 per 1000 live births in 1998-99 compares favorably with 127 in 1991 (Table III-5). However, infant mortality in Pakistan still compares poorly with comparable countries in the region-mortality rates are 70 for India and 61 in Bangladesh. While no significant gap in infant mortality exists between male and female children in Pakistan, there is a large nural-urban gap of 18 percentage points, and an even larger gap of 34 percentage points between infants born of women with some education, and those born of women with no education. Infant mortality rates are also significantly lower for households with access to facilities like piped drinking water, covered underground drainage systems, and toilets inside the residential building.

\footnotetext{
${ }^{17}$ The share of madrassas in aggregate enrollment is found to be miniscule, amounting to no more than
} 0.7 percent of all students currently attending school nationwide 


\section{Information on pre-and post-natal care, and statistics on the conditions} surrounding childbirth are indicative of female health in Pakistan. From the PIHS data of 1998 -99, incidence of pre-natal medical consultation among married women (of age 15-49) is found to be low in general ( 31 percent), with very large differences between rural and urban regions ( 22 percent and 60 percent, respectively), and within regions among various expenditure groups, as well as women of differing hiteracy levels. Similar patterns are observed in other related indicators. As far as the rate of contraceptive use - an important indicator for fertility-is concerned, the actual use of contraception from 1991 to 1998-99 (10 percent to 20 percent) has increased far less than knowledge of contraceptive methods ( 38 percent to 92 percent). As expected, there are wide differences in use of contraception, by rural and urban areas (14 percent and 34 percent respectively), economic status and the woman's education.

Table III-5. Pakistan: Infant Mortality, 1991-99

(Per 1000 live births)

\begin{tabular}{lcc}
\hline & 1991 1/ & $1998-992 /$ \\
\hline All Pakistan & 127 & 83 \\
Urban &. & 70 \\
Rural &. & 88 \\
Male &. & 85 \\
Female &. & 81 \\
By Mother's education: & & \\
No education & 134 & 90 \\
Some education & $\mathbf{8 1}$ & 56 \\
Drinking water: & 117 & 70 \\
Piped indoor & 121 & 90 \\
Outside home (covered) & 156 & 83 \\
Open source (river, pond) & & \\
Drains: & 94 & 54 \\
Covered underground & 120 & 89 \\
Uncovered open & 141 & \\
None & & 73 \\
Toilet: & 105 & 95 \\
Yes & 132 & \\
No & & \\
\hline
\end{tabular}

1/ Source: World Bank (1995)

2/ Source: PLHS (1998-99). Infant mortality rates were calculated as averages for children born in the period 1993-97, to ensure that only infants who would be of age 1 and above (if they were alive) are considered. 
45. A particularly important health issue in Pakistan is the persistence of chronic child malnutrition in rural areas. Preliminary survey findings from four rural districts present a stark picture of chronic malnutrition, which has shown virtually no improvement over the 15 years covered by the surveys. ${ }^{18}$ The most recent information from 2001 indicates that in these districts, by the time a child reaches age 5 , he/she has a 62 percent probability of being stunted, 45 percent likelihood of being underweight, and 12 percent chance of being in a wasted condition (Figure III-2). There are also significant regional variations; and notably, both female and male children appear equally affected by this trend. The findings also show that chronic malnutrition tends to start early in childhood. These findings are particularly important in the light of research from other countries that show nutrition in early childhood to be critical for long-term human development, and the relative inefficacy of interventions beyond the second year of the child.

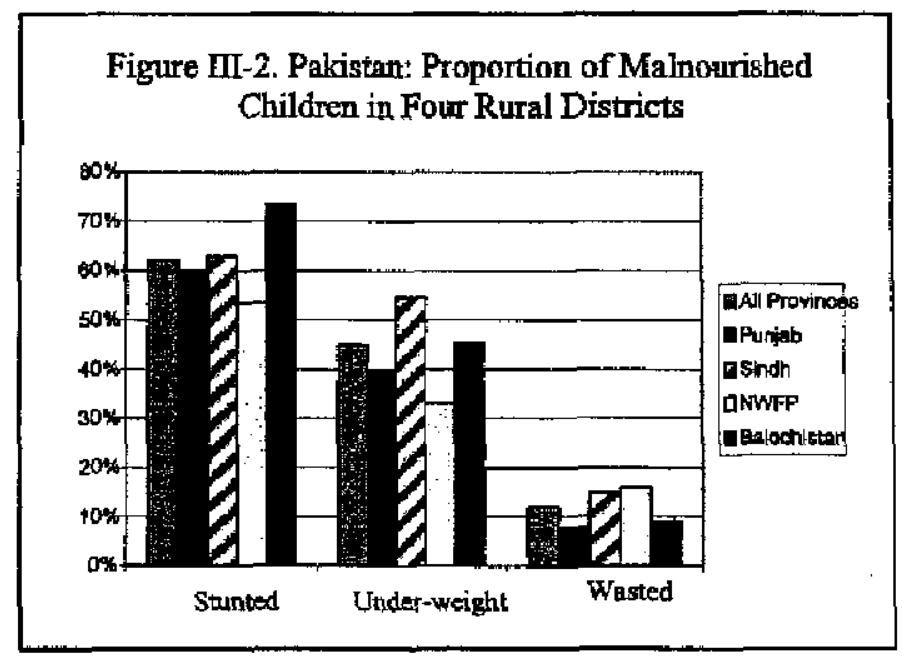

46. There is also evidence that the rate of immunization, which represents a key indicator of preventive medical care with strong implications for infant mortality and health, is low in Pakistan, in spite of some improvements made over the decade. Data from PIHS reveal that only about half of the children in the country were immunized in 1996-97, implying that the national health system failed to reach over 9 million out of 19 million children of age five and under.

\section{How Low Education and Health Affect Growth and Poverty}

47. Human development, as measured by education and health indicators, has been found to be an important determinant of long-term growth. ${ }^{19} \mathrm{~A}$ cross-country growth

\footnotetext{
${ }^{18}$ The specific surveys are those conducted by the International Food Policy Research Institute (IFPRI) between 1986 and 1989 in four rural districts, and the recent PRHS (2001) survey.

${ }^{19}$ Bârro (1998).
} 
regression prepared as background paper to the latest Pakistan poverty assessment ${ }^{20}$ indicates that among the factors that impact long-term growth in per capita income, the education variable is among the most important, and remains stable across different specifications. A 10 percent increase in the initial secondary enrollment rate is found to result in a 0.5 percent increase in the subsequent decadal average per capita growth rate.

\section{The impact of education on Pakistan's growth can most easily be quantified} through some simple counterfactual exercises that calculate growth trajectories for Pakistan, based on the coefficients from the regressions, under the hypothetical scenario of it having South Korea's and Malaysia's levels of human capital in 1990. ${ }^{21}$ In 1990, Pakistan's secondary enrollment rate was 23 percent, compared with 56 percent for Malaysia, and 90 percent for South Korea. The model predicts that with the Korea's enrollment, Pakistan's per capita GDP would have grown on average at almost 3 percent, as opposed to the actual 1 percent, and in 1999 would have been about 20 percent higher than actual.

\section{Evidence from micro-data also underscores the important role played by} education and health in raising incomes and reducing poverty. Findings from PIHS (1998-99) suggest that education has significant impact on earnings, particularly in the urban econorny. Education is associated with lower incidence of poverty- -42 percent of the population living in households with illiterate heads are found to be poor, compared with 21 percent of those in other households. Estimation exercises indicate that a worker's own literacy and education have positive effects on individual eamings for all nonfarm workers. For instance among males, literate workers eam 42 percent and 9 percent more than nonliterate workers in the urban and rural nonfarm sectors, respectively. Literacy or education variables however have no significant effects on earnings in the rural agricultural sector. In rural areas, male and female workers who are educated and literate are far more likely to participate in the nonfarm sector. ${ }^{22}$

\footnotetext{
${ }^{20}$ World Bank (2002). The cross-country growth regressions use decadal average growth rates as the dependent variable, OLS estimation, and decadal averages of all explanatory variables, except for initial income and secondary school enrollment. The other explanatory variables are: dummies for each time period, the black market premium as an indicator of trade, exchange rate, and price distortions; financial depth (the ratio of liquid liabilities of the financial sector to GDP); changes in terms of trade to capture the effect of external shocks; and the effects of goverument fiscal policy (fiscal surplus and government current expenditures). Two of the specifications include alternate governance indicators: International Country Risk Guide (ICRG) indicator or "contract intensive money (CIM)" - the ratio of noncurrency money to total money-to capture the quality of political institutions. Notable among other explanatory variables, there exists a negative and significant relationship between initial per capita income and growth, which is expected. In addition, reduction in fiscal deficit and better governance indicators are also found to have a significant positive impact on long-term growth.

${ }^{21}$ For both these countries, a substantial literature has emphasized the early investments in education as a key to their subsequent high economic growth

${ }^{22}$ World Bank (2002).
} 
50. Beyond individual benefits however, investments in education also yield large intra-household externalities. ${ }^{23}$ These include positive externalities of education on earnings of household members, arising out of the fact that for a nonliterate worker, there may be benefits from having easy access to a literate household member. For instance, an illiterate urban worker who has to be aware of employment opportunities or requires information in order to bargain with employers, might benefit considerably from this. Estimations using PIHS data show that having a literate member in the family has positive and significant effects on earnings of nonliterate urban workers, and especially so for male workers. In comparison, externalities are generally weaker for female wage earners, and for the rural nonfarm sector compared with the urban sector; they are nonexistent for the rural farm sector. ${ }^{24}$ The presence of these externalities carries a powerful policy implication-namely, the importance of the spread of literacy and education among the population.

51. The pattern of education being more important for wage earnings in the nonfarm sector is consistent with what one would reasonably expect, given that wage earners in the farm sector are likely to consist mostly of daily wage labor engaged in activities with low or nonexistent returns to education. The pattern of education having higher direct returns and externalities on earnings in the urban sector; compared with rural areas, is also consistent with expectations since urban areas are likely to offer greater range of opportunities to workers with more education or are better-informed about job opportunities (as a result of having educated members in the bousehold).

52. Externalities of education also arise from parents' education, and notably, mother's literacy and education is associated with lower infant mortality rate, higher enrollment rates of children, and smaller gender differences in enrollment of children. As shown in Table III-5, mothers' literacy is associated with lower infant mortality. Simple cross-tabulations also show that when mothers are literate, the school participation rate of children is higher, and the urban-rural differential - as well as gender differences-are significantly lower. The aforementioned multivariate regressions to explain school participation of children show that the marginal effects of whether the parent has ever attended school are high and significant for mother and father alike. Having a mother who has attended school makes it 23 percent more likely that a child will also do so; having a father who has attended school makes it 16 percent more likely that a child will do so.

53. The health status of the population also has important implications for futare earning capacity of individuals, and therefore the likelihood of being poor. In the context of Pakistan, the poor status of maternal and child health likely perpetuate poverty in the long

\footnotetext{
${ }^{23}$ Existing literature has found evidence that having a litexate family member is like being partly literate oneself (Green et al, 1985), and that the advantages of literacy can spread to others in the household by virtue of certain kinds of household decision-making shifting toward the literate (Drèze and Saran, 1995).

${ }^{24}$ World Bank (2002) for a detailed explanation of these estimation exercises.
} 
In the light of evidence showing widespread malnutrition among children at an early age in Pakistan, it is particularly important to note that poor nutrition in an individual's early childhood has lasting repetcussions for the productive work-life of the adult, and also that interventions to improve mutrition during the first two years of childhood are likely to have the most significant impact on future development. ${ }^{25}$ Such findings underline the importance of policies that target nutritional programs during pregnancy and earty childhood years, from the point of view of improving human capital and reducing poverty.

\section{E. What Explains Education and Health Outcomes in Pakistan}

54. Regression analyses based on household data provide the starting point for looking at the range of factors that explain the observed outcomes in education and health in Pakistan. The aforementioned multivariate regression to explain school participation of children of age 6-14 years indicates, for example, that both supply and demand factors play important roles. On the supply side, access to school facilities is found to be critical for girls' schooling in particular; the probability of a girl attending school is increased by 15 percent by the presence of an appropriate primary school within one kilometer of the village. For a village with a primary school for girls within one kilometer, the net primary enrollment rate for girls is 43 percent, compared with 13 percent for the rest of the rural population.

55. In terms of access to schooling, the PIHS data reveal that about 79 percent of the rural population live in areas where there is at least one primary school for girls in or within one kilometer distance from the village. There are large regional variations-ranging from 100 percent in certain areas to 41 percent for Balochistan. Access to primary school for boys, on the other hand, seems to be uniformly high across the country; 95 percent of the rural population lives in areas where the nearest primary school for boys is within one kilometer of the village. Such differences in the availability of primary schools for girls and boys in rural Pakistan no doubt partly explain wide gender gaps in schooling outcomes. Related to this, a recent study of private schooling indicates that low female enrollments are closely linked to institutional defects in the public school system that limits access of girls to school facilities. ${ }^{26}$ The experience of private schools points up ways to address these defects, in order to expand access to schooling for girls (see below).

56. Lack of availability of schooling facilities, however, provides only a partial picture of the factors constraining education in Pakistan. A better understanding of what limits school participation requires exploring factors-like caste or social hierarchies - that

\footnotetext{
${ }^{25}$ For example, a longitudinal study in Guatemala reported in Martorell et al. (1995) showed that while supplements in the first two years of the childhood had significant impacts on adolescent intelligence and adult work-capacity, interventions during the later childhood years did not have any such benefits

${ }^{25}$ Andrabi et al. (2002).
} 
limit access to groups; examining the quality of available schooling; and examining demand side considerations, which are in turn likely influenced by issues of quality and access.

57. Firstly, the mere presence of a school may not necessarily make it equally accessible to all members of a local community; caste or social hierarchies may influence access. A recent study finds that interaction of caste relationships and public services can produce a range of outcomes, with very different policy implications. ${ }^{27}$ While in some cases, properly functioning public facilities tend to eradicate caste-based differentials, in other areas there is evidence that existing social hierarchies compromise the very functioning of these public services. In these areas, true public access to these services is likely to become possible only through political empowerment of marginalized groups.

58. Secondly, the mere existence of a school does not imply that it offers quality education, or even that it meets the minimum standards of a functional school. Result from the PRHS facilities survey evidence widespread quality problems, ranging from teacher absenteeism to lack of amenities. Out of the 206 rural schools surveyed in a sample of around 130 rural communities, classes were not being held in 34 at the time of the visit. ${ }^{28}$ In schools where classes were being conducted, the rate of teacher absenteeism was around 20 percent. Since the majority of rural schools are single or two-teacher establishments, these aggregate numbers in fact understate the disnuption to education caused by teacher absenteeism at the individual school level. Lack of infrastructure and amenities was also widespread: only a third of the sample schools had an adequate building; ${ }^{29}$ only about half the schools had access to drinking water and toilets; 23 percent had adequate supply of textbooks; and 16 percent of the coeducational schools had a separate toilet for girls.

\section{Given these problems with facility quality, it is no surprise then that student} attendance rates were rather low-approximately 64 percent of enrolled boys and 61 percent of enrolled girls were observed to be present at the time of the visits. The survey data revealed significantly lower student attendance rates in facilities lacking toilets, furniture, textbooks, drinking water, electricity, and an adequate building (Figure Ш-3). Also, linking household level information on enrollment with facility level information, one finds that higher enrollment rates are associated with better quality of amenities in schools. Among girls of primary school age in communities with schools with adequate amenities, the net enrollment rate is 42 percent, in comparison to 32 percent in communities where the local

\footnotetext{
${ }^{27}$ Gazdar (2000).

${ }^{28}$ These findings from the PRHS, although based on a different sample, are toughly similar to Gazdar (2000) findings. The latter found that 14 percent of the 125 schools visited (i.e., 17 schools) had either a building but no school, or were reported to be "generally closed".

${ }^{29}$ A building is defined "adequate" if at least 2 out of the 3 major components-floor, walls, and roof - do not need major repairs.
} 
girl's school lacks amenities, and 24 percent when there is no girls' school in the community. These results indicate that quality and functionality of schools, over and above their mere presence, matter for school participation.

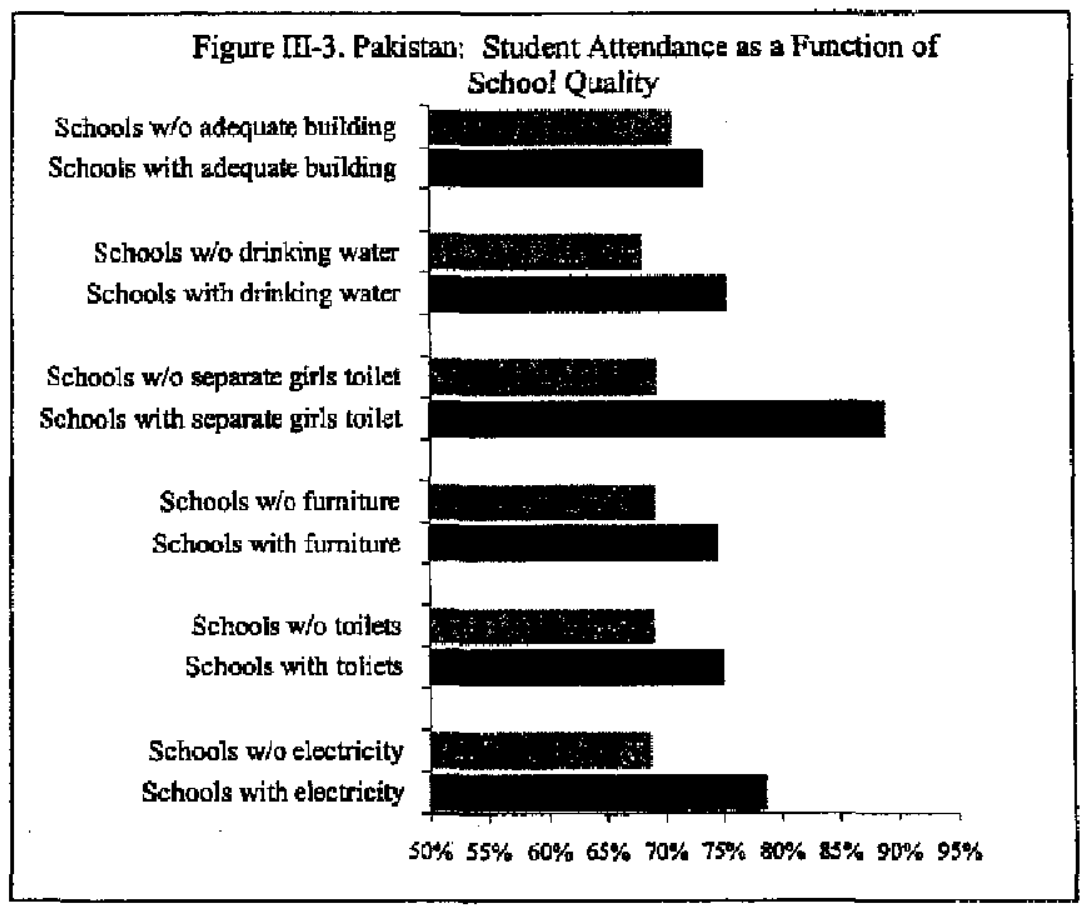

60. Thirdly, multivariate analysis of school participation confirms the importance of demand-side factors in determining the school partictpation. As mentioned previously, the probability of participation increases significantly if the child belongs to a higher expenditure group or has educated parents. Household social attitudes also have a role in determining school attendance, particularly for girls. Subjective results from PIHS point up that for all of Pakistan, parental disapproval is more frequently cited as a reason for girls never attending or leaving school than it is for boys, by a margin of 39 percent and 18 percent versus 6 percent and 4 percent in rural and urban areas, respectively.

61. It is however important to note that demand side responses are influenced by supply factors: parents may well have little incentive to send their children to far away or nonfunctioning schools. Such interplay of both supply and demand side factors only emphasizes the importance of crafting comprehensive educational policies in Pakistan, focusing on institutional reforms to expand availability and improve quality of education facilities, as well as providing appropriate demand side incentives to households to send their children to school.

62. In determining health outcomes, along with various household characteristics like education, social attitudes, cultural mores, and access to information, availability and quality of facilities appear to play important roles. Access to health services is far from 
universal in rural areas--38 percent of the nural population in the PIHS sample live in villages with a government hospital, dispensary or clinic. Infant and child mortality rates, for males and females alike, are lower for villages with a hospital, dispensary, or clinic. Similarly, availability of health facilities in the community is also associated with higher indicators of matemal health care.

63. In addition, an important finding of regression analysis based on PRHS data, ${ }^{30}$ is that the average economic status of the community is likely to be most important to a child's health. Estimation results show that the relationship between expenditure and nutritional status is almost entirely driven by differences in the average per capita consumption across communities. Richer communities have taller and less underweight children, but once the average per capita income of the community is controlled for, there is little impact of household expenditure on anthropometric outcomes for children across different households in the community. This finding however begs the question of what specific characteristics such community level fixed effects represent. A reasonable hypothesis may be that wealthier communities command better facilities, likely because they are in a better position to influence the location of a health facility, as well as ensure more regular, high quality operation compared with a poor village. ${ }^{31}$

64. There is no direct evidence to support this hypothesis, partly because record-keeping at the facility level was of insufficient quality to provide important data on quality indicators. Further investigation is thus needed, using detailed facility level information linked with nutrition data. Preliminary and rough indicators of quality, such as patterns of outpatient visits and personnel records in the PRHS sample, do indicate that wide quality variations exist across health facilities. For instance, while the top three Basic Health Units (BHUs), ranked in tetms of outpatient visits for a one-year period (separated by month), regularly show more than 1,500 visits per month, the bottom three consistently report no visits for each month during the year. Evidence from secondary sources also indicates a dearth of qualified doctors, and there are serious questions about public facilities where rampant absenteeism of medical personnel and severe shortages of equipments and medicines are reported.

65. Regardless of what specific factors explain intercommunity differences in anthropometric outcomes, the very impact of these differences suggest that health policies should target relevant health care interventions, including preventive care initiatives, to poorer communities. Moreover, in the light of available evidence on deficient and highly variable quality of services, expanding the availability of health facilities must be accompanied by measures to ensure the quality of service.

\footnotetext{
${ }^{30}$ For details, see Annex, World Bank (2002). Similar results have been noted in Alderman et al. (2001) for anthropometry in Perı.

${ }^{31}$ See for instance, Thomas et al (1992).
} 


\section{F. Explaining the Social Gap: the Bias Against Social Spending}

66. The evidence so far provides a strong basis for concluding that the scarcity and poor quality of public services is a significant constraint to progress in health and education. This suggests that more investments in factlities, despite potential demand-side problems, should have a strong impact on health and education outcomes accompanied by steps to correct the institutional failures that have hampered access to quality services in the past.

67. In this regard, attention should first be drawn to the fact that social spending in Pakistan has historically been insufficient. This is partly due to the constraints imposed by the country's heavy debt burden and high military expenditures. That said, social spending rather than other types of "discretionary" spending, such as public investment, seems to have borne the brunt of the adjustment to these other expenditures. As Figure III-4 shows, throughout the 1980s, social spendingcomprising largely recurrent spending on items such as teacher salaries, textbooks, and medicines-hovered around 2.5 percent of GDP, while development spending-largely for public investment or infrastructure such as roads, irrigation, and bailding - comprised about 7 percent. This relationship was briefly reversed during $1992-98$, when social spending rose to 4 percent of GDP, largely due to an infusion of US\$2 billion in external assistance in support of the Social Action Program.

68. Moreover, even after development expenditures had fallen substantially relative to social service expenditures in the $1990 \mathrm{~s}$, cross-conntry comparisons indicate that social spending still remained low relative to infrastructure spending. For example, education spending was 1.8 percent of GDP in Pakistan in 1998, compared with the 2.5 percent of GDP allocated to public investment. In Sri Lanka, on the other hand, education spending was 5.3 percent of GDP, compared with a similar rate of public investment of 2.6 percent of GDP. ${ }^{32}$

\footnotetext{
${ }^{32}$ The World Bank country office is the source for education expenditures in 1998 in Pakistan. Government Financial Statistics is the source for the remaining three expenditure information. 1998 is the latest year for which data is avaitable for all variables.
} 
69. The rełative lack of attention to social spending in Pakistan has had particularly adverse consequences for the poor, since they tend to derive disproportionately high benefits from such services. For instance, in the case of Pakistan, a rough benefit-incidence analysis of public expenditure on education reveals that spending on primary education, in particular, is strongly pro-poor (Table III-6). This is however not the case for spending on secondary and tertiary education, primarily because of the low participation of the poor at such levels. ${ }^{33}$

Table III-6. Pakistan: Benefit and Distribution of Public Spending in Education, 1998-99

\begin{tabular}{cccccccc}
\hline \multirow{2}{*}{$\begin{array}{c}\text { Per capita } \\
\text { consumption } \\
\text { quintiles }\end{array}$} & \multicolumn{2}{c}{$\begin{array}{c}\text { Per capita benefit of public education } \\
\text { spending (in Pakistan rupees) } / /\end{array}$} & & \multicolumn{2}{c}{$\begin{array}{c}\text { Distribution of public exp. on ecucation } \\
\text { (percentage share) }\end{array}$} \\
& Primary & Secondary & Tertiary & & Primary & Secondary & Tertiary \\
\hline & 185 & 55 & 10 & & 20.9 & 11.4 & 3.1 \\
2 & 219 & 85 & 27 & & 24.7 & 17.6 & 8.1 \\
3 & 194 & 101 & 39 & & 21.9 & 20.7 & 11.8 \\
4 & 180 & 124 & 65 & & 20.3 & 25.5 & 19.9 \\
5 & 110 & 122 & 187 & & 12.3 & 24.9 & 57.0 \\
Average & 178 & 97 & 65 & & & & \\
\hline
\end{tabular}

Source: PIHS (1998-99).

1/ Benefit of primary public education spending per capita for expenditure quintile $k$ is calculated as (total public expenditure on primary schooling/total number of public primary school students in population) $x$ (number of primary public school students in quintile $k$ /total population in quintile $k$ ); similarly for secondary and tertiary spending.

\section{Debt, growth, and the social gap}

70. It has been argued that focusing public expenditure better towards the objective of closing the social gap should be a priority of public policy in Pakistan. As previous discussion suggests, such a shift of priorities is likely to translate into higher long-term growth, which in turn will be critical to reverse adverse public debt dynamics.

71. Only a combination of fiscal adjustment and a return to high growth would allow the country's debt ratio to decline to more manageable levels. While fiscal adjustment is necessary, given that human development is a key determinant of long-term growth, it will be imperative to avoid adjustments that adversely impact social sectors. Most

${ }^{33}$ It is important to note that such static benefit-incidence is quite limited for measuring the impact of public spending, since takes the usage rate of public services as given, not taking into account the dynamic effects of spending an additional dollar on the use of public services. 
importantly, closing the social gap while maintaining fiscal discipline that will impose strict limitations on spending, will require undertaking reforms that enhance the efficiency of social spending, by addressing institutional failures that distort incentives to provide quality public services.

\section{G. Quality of Public Social Spending}

72. Public social spending in Pakistan is not only insufficient, but also utilized inefficiently. A recent World Bank study of local public expenditures for Punjab, the most populous province in Pakistan, is useful to highlight some of the systemic problems. ${ }^{34}$ The study indicates that the province's poor social indicators result not only from low spending on the social sector, but also from inefficiencies in the use of the limited resources thus provided.

73. Punjab's educational budget, at about 2.1 percent of provincial GDP, is about two-thirds of what is spent in nelghboring India and Sri Lanka. Actual allocations are even less than these budget targets indicate, falling short by as much as a quarter in recent years. Despite the explicit aim of the Social Action Program (SAP) to boost expenditures, average real spending per student was stagnant during the $1990 \mathrm{~s}$. The amount allocated to nonsalary inputs such as teaching materials, a critical determinant of school quality, has also remained very low-in 1997-98, 97 percent of the elementary education budget was spent on teacher salaries. Moreover, restrictions on the use of the nonsalary budget have resulted in underspending of the already limited budget allocations for nonsalary expenditures.

74. Punjab's health expenditure of approximately 0.5 percent of provincial GDP is similarly low by international standards - - the average expenditure for all low and middle income countries is roughly 2 percent of GDP. At about a third of total expenditures, allocations for nonsalary inputs are insufficient, with the result that government health facilities routinely run out of medicine and other supplies. For example, in the last quarter of 1999, half of the primary health care facilities in the province reported that supplies of three essential drugs had been completely exhausted.

\section{Institutional obstacles have played a key part in reducing the quality and} efficiency of social spending in Pakistan over the years; notably so in the case of the country's SAP, which to date represents the most concerted effort by its government and donors to address the social gap. SAP was launched in 1992/93, with the aid of donor financing and technical assistance, with the objective of social development in four target areas-elementary education, basic health care, family planning, and rural water supply and sanitation. The program has had some successes: improvements have occurred in some health indicators, access to related infrastructure; immunization; and availability of Lady Health

\footnotetext{
${ }^{34}$ World Bank (2001a).
} 
Workers-health workers who focus on female and child health. However, the gains have been marginal, and especially so in education, which has been the major area of focus.

76. In explaining the lack of success of SAP, it is important to note that it appears to have focused more on accelerating construction of facilities than on increasing the supply of educational materials, medicines, and the on-the-ground delivery of services. Evidence also suggests that the mechanisms through which SAP was sought to be implemented provided powerful vehicles for patronage, to the detriment of community participation and often in direct conflict with the planned goals. ${ }^{35}$ For example, while many local landowners were willing to provide land for a school in their village, the motivation in most cases was that they could then hire teachers for the school as an act of patronage. This resulted in the phenomenon of "ghost schools"- - schools that exist on paper, but do not have any teacherswidely reported in some areas, and other forms of less extreme patronage. The extent of patronage in the program likely had serious exclusionary effects on those communities that did not belong to the right political faction, giving rise to stark inter and intra-district disparities. The experience of SAP underlines the difficulties of an approach that focuses primarily on infrastructure-building, without adequately addressing severe institutional obstacles or demand-side constraints to social progress. Addressing these problems will require a close look at the political economy related factors that are responsible for distorting the incentives to provide quality public services.

\section{Governance and the political economy of service delivery}

77. In education and health alike, under-provision and poor quality of public facilities-it will be argued below - are largely attributable to two factors. The first of these are skewed incentives set by the nonformal parameters of political competition in Pakistan's nural areas, which reduce the willingness of elected politicians to provide quality public goods of certain types. Second, there is also evidence of social resistance that appears to reduce demand for certain services by some constituencies, in particular education for girls.

\section{Traditional explanations of the incentives of political decision makers in} Pakistan have focused on elite capture of the state and the fractionalization of Pakistani society. ${ }^{36}$ The elites, benefiting little from public spending directed at the poor, and in some cases threatened by it (education), were said to block fiscal reforms. Due to the feudal structure prevailing in large parts of rural Pakistan, the "rural gentry" have always had exceptional influence in Pakistan. That said, the political hold that landlords exert on rural inhabitants can be easily overstated. First, landlords are not a monolithic class and compete

\footnotetext{
${ }^{35}$ See, for instance, results from a field survey conducted by Ercelawn and Zaidi (1999). They also found little evidence of NGO involvement in SAP, contrary to one of its stated aims--indications were that NGOs had little or no contact with SAP-related elected and non-elected rnombers.

${ }^{36}$ Easterly (2001).
} 
vigorously among themselves for political office. Second, anthropological evidence shows that rural inhabitants were less reliant on landowners in the 1990 s than earlier, as many of the new generation of landlords moved away from their villages.

79. A survey of $\mathbf{1 2 5}$ primary schools in selected rural locales in Gazdar (2000) indicates that while failures in the provision of government services are particularly acute in rural Pakistan, it will be simplistic to trace all failures back to landlords. Specific landlord influence was visible in several of the cases where schools were dysfunctional, but it was neither unambiguously pernicious, nor was it sufficient to explain the pervasive breakdown of the educational system that was observed. It is also easy to overstate the extent to which the political and rural elites ignore the poor. Rather, the evidence suggests that they are selective in what they provide the poor. Although rural constituencies have been denied universal access to schooling and better health facilities, they do not seem to have lagged in access to other public goods. Pakistan's relatively high-and commendable — rate of access to potable water is an example of elected officials' emphasis on providing targeted benefits. ${ }^{37}$ Given the evidence, an examination of the political economy of service delivery needs to move beyond the monolithic framework of landlord domination of the political process.

\section{Distortions in the competition for the votes of the poor}

80. In view of the importance of elected local governments under the ongoing devolution initiative, the important phenomenon to analyze is the source of distortions in public expenditure under the elected governments of the $1990 \mathrm{ss}$. In that context, the first characteristic of electoral politics in Pakistan that undermines the provision of public services has been that political parties have not been able to make credible claims regarding their performance in service provision. As a consequence, from the point of view of citizens, the credibility of politicians depends on their personal reputation for providing goods, jobs, and government access to individuals with whom they have had contact. The second characteristic of electoral politics in Pakistan under the impermanence of elected governments. This shortens the political horizons of decision makers, and reduces the penalty to them of reneging on any electoral promises that they do make. Further, in this scenario, the local elite are often powerful because they can make credible promises to local residents, leveraging a local reputation that is independent of the comings and goings of national governments.

81. These characteristics of political competition in Pakistan explain why spending on infrastructure, such as market roads and water, is largely relative to that on edncation and health services; and why public officials prefer new investments and

${ }^{37}$ Compared with countries with similar incomes per capita and population characteristics, access to potable water in Pakistan in 2000 was found to be 25 percentage points higher than expected - diametrically opposite to what is seen for education and health indicators. 
major rehabilitation projects over more cost-effective options of maintaining existing facilities. The infrastructure-based public goods provide immediate and easily assessed benefits in the form of construction jobs and flow of services-especially important where political instability is great and current politicians are unable to credibly promise future benefits to constituents. And they can be narrowly targeted to supporters - especially important where voters, particularly rural or poor voters, perceive that their ability to obtain goods and services from the state depends on personal relationships.

82. Universal access to education and health, including broad improvements in the quality of teachers or curricula, do not share these two characteristics. As public goods, improved curricula and better oversight of school performance, can less easily be targeted; further, they cannot be easily sustained over a longer period of time without additional effort. Moreover, the benefits of political efforts to maintain highways or improve school quality are difficult for constituents to perceive, especially in the short run, further reducing their utility to policymakers with short horizons. More importantly, the larger and more concentrated the effects of an expenditure, the easier it is for constituents to give credit for it to their personal representative.

\section{The poor and the demand for public goods}

83. While there are structural reasons for elected officials in Pakistan to expend less effort on providing education and health services for their constituents, there is some evidence that their constituents themselves may prefer spending on certain types of infrastructure relative to improved education and health. For example, in systematic surveys and, especially, in informal contacts, the rural poor frequently place access to water ahead of improvements in access to and the quality of education, especially female education.

84. However, if public policy in Pakistan were oriented towards the efficient provision of desired infrastructure, such as water resources and market roads, one would not expect to see considerable waste and leakage in infrastructure construction, and stark breakdowns in the maintenance and operations of physical irfrastructure once provided. The prevalence of these suggests that more is at work than skewed demands for public services. The short horizons of political decision makers and their focus on targeted goods rather than broad public policy issues provide some explanation for these problematic aspects of infrastructure provision. This also has implications for institutional reforms such as decentralization, as discussed below.

\section{H. Pakistan's Devolution Reforms: Significance for Service Delivery}

85. Improving the accountability and incentive mechanisms of public service delivery is one of the primary objectives of the comprehensive plan of devolution being implemented in Pakistan. The plan envisages creating full-fledged district governments with legislative and financial powers, serving below the federal and provincial levels. Yet this devolution effort can be expected to succeed only to the extent that it solves fundamental 
governance problems that have bedeviled earlier efforts, like SAP, to improve service delivery. In particular, it will succeed if local government officials exhibit a greater interest in improving the provision of public goods than in targeting private goods.

85. To date, there is reason for being somewhat optimistic about devolution boosting official interest in improving the provision of public goods. The optimism stems from the possibility that the institutional changes introduced by devolution are likely to reduce incentives for patronage. Newiy elected local officials will confront greater political costs in undermining education and health provision in order to generate patronage opportunities, relative to provincial and national government officials who have controlled these sectors in the past.

87. The second reason for optimism is that with devolution, there are potentially more checks operating on officials who try to provide patronage. Until now, the highest district officials have been able to make decisions in a strictly hierarchical fashion. Under devolution, the District Nazims can be checked by the district councils, provided that the councils and Nazims be independent of each other (that the elections at the local level be competitive).

88. However, two important issues regarding service delivery are not likely to be solved by devolution. First, there are severe distributional inequities in the provision of health and education, extending across districts. Inequities in access to services also arise from social obstacles to service delivery that are exacerbated by local governance failures. Qualitative studies have found that interaction of caste relationships and public services can in fact produce a range of outcomes-from scenarios where properly functioning public facilities tehd to eradicate caste based differentials, to those where existing social hierarchies compromise the very functioning of these public services. In the latter scenario, the local government typically lacks the ability or incentive to overcome social barriers in providing universal access to service delivery, and addressing the problem would require attention at higher levels of government. Second, there are significant demand-side problemsdifficulties in encouraging families to take full advantage of the services that are made available. This appears to be especially true in the context of parental resistance to girls? education in nural areas.

89. Experiences in other countries suggest that when incentives of local governments are weak or even perverse, due to social barriers to reform, the involvement of higherlevel govermments becomes necessary. For example, addressing demand-side issues iike resistance to girls' education may require interventions in the form of incentives, monetary, and otherwise, to parents. The widely implemented Bangladesh Food-for-Education and Female Education Scholarship programs link food transfers and scholarships to poor households to primary school enrollment of their children, particularly girls. In Pakistan itself, Food for Schoolgirls run by the World Food Program (WFP) has been implemented on a limited scale in selected girls' primary schools in rural Balochistan and NWFP, with some success. 
90. Another possible intervention at the federal or provincial level could occur through fiscal transfers to districts. For instance, cross-sectoral incentives to districts can be devised, whereby monetary support for the provision of goods (such as infrastructure) that are heavily demanded are linked to better performances in the social sector. There may also be a need for central government monitoring to ensure that informal incentives and greater local powers do not subvert the new formal rules of political competition.

\section{Inducing Private Provision of Education and Health Services}

\section{An additional element in future strategies to increase access to health and} education should be to recognize the already important role of the private sector. As noted before, there has been considerable growth in private schooling since the denationalization of 1979. Since 1990, there has also been a qualitative shift in the establishment and operation of private schools leading to broader access.

92. From 1990 to 2000 , the proportion of private schools established in rural areas has increased from 20 percent to about 50 percent, although enroliment in urban private schools is still three times that in rural private schools. Moreover, recent findings call into question a number of prior beliefs about the elite nature of private schools. In particular, it appears that tuition fees in private schools are not set so that they cater only to the wealthy. Private schooling actually turns out to be cheaper than public schooling, in terms of total resources spent per student. ${ }^{38}$

93. There is also some evidence that private schools have a positive impact on female enrollment. As mentioned before, a recent study of private schooling points up the advantages that private schools seem to enjoy over public schools; gender differences in their enrollments are found to be low, primarily because these mostly coeducational schools do not restrict girls' participation, but also because these schools have been able to employ large numbers of women as teachers. The private school experience suggests lessons for strategies for schooling provision in general. It appears that to improve female enrollments, it may be more important to locate schools admitting girl students closer to communities, rather than to focus on single-sex institutions that cannot be universally provided. This might also help create local virtuous cycles for female education; the analysis suggests that on the one hand, increasing the number of female teachers encourages girls schooling and on the other, an increase in the number of educated women in the community raises the local supply of

\footnotetext{
${ }^{38}$ The relevant comparison between costs of public and private schooling is between the fees paid by households for private schools on the one hand, and the fees plus the public spending on schooling on the other for public schools (Andrabi et al, 2002).
} 
private schools. In this respect there therefore appears to be a unique opportunity for Pakistan to radically improve the status of female education. ${ }^{39}$

94. The rapidly expanding role of the private sector in educational provision in Pakistan has obvious implications for educational policy in the country. Accordingly, the government of Pakistan's Education Sector Reform (ESR) program recognizes the opportunities embodied in this growth of private education, and rightly places a high priority on strengthening public-private partnerships in the delivery of educational services.

95. Measures proposed by the ESR, including fiscal incentives such as concessional rates on land and utilities and increased endowments for the Education Foundations, are weicome in light of the government's questionable ability to quickly extend universal access. Further, a possible future reform to consider would be to provide vouchers to parents for enrolling children at private schools, or as direct subsidies to private schools. The Quetta Urban Fellowship Program is one interesting example of the use of such subsidies, whereby private schools controlled by communities in poor neighborhoods of Quetta were encouraged to establish new facilities for girls through subsidies paid directly to the schools. While boys could also enroll in the fellowship schools, they could not make up more than half the total enrollment, and schools received no subsidy for enrolling boys. An evaluation of the program reveals that it had a positive impact on female enrollments, increasing girls' enrollment in the target neighborhoods by about 33 percent. Interestingly, boys' enrollment rose as well, partly because boys were allowed to attend the new schools, and partly because parents would not send their girls to school without also educating their boys. ${ }^{40}$

\section{Notably however, subsidies to private schools or vouchers to parents entail} complicated choices. The arguments in favor of subsidies are that private schools are more efficient and that public-private competition tends to improve quality. These need to be weighed against counter-arguments that contend that scarce public resources would be better spent in improving the public school system, which has more universal reach. The nonstandardization of private educational provision imposes additional problems, since parents find it difficult to distinguish between low and high quality schools, which can lead to inefficient outcomes if poor quality institutions can get away with charging high prices. A proper regulatory framework is crucial to address these potential informational problems, with the important caveat that this framework not be so burdensome that it forces private schools to raise their fees in response to higher costs.

97. One key intervention in this context would be to assess how private schools' test assessment outcomes compare to public schools, and whether these test outcomes correlate positively with prices in the private sector. The absence of a price-quality

\footnotetext{
${ }^{39}$ See Andrabi et al (2001) and World Bank (2002) chapter 3, for a detailed analysis of private schooling and public-private comparisons.

10 See Alderman at al (1999).
} 
relationship would indicate that households face problems in learning about the quality of a school. In that case, a national assessment mechanism with published test results can help in providing public information on quality and greatly facilitate informed parental choice that is critical for a successful voucher program. A thorough evaluation of such issues would address the important question of whether using the private sector and providing educational subsidies to poor households can be an efficient policy lever, to some extent supplanting complete reliance on the public sector to expand primary education.

98. Private-public sector partnerships can also be advanced in health, as noted by the government's Health Policy. The measures considered include requirements that every medical college in the public and private sector adopt at least one district hospital or primary health facility in addition to the teaching hospital affiliated to it. There are also regulatory reforms directed at the private sector, specifically with regards to the accreditation of private hospitals/clinics, and at improvements in the government's capacity for quality control of drugs.

\section{J. Conclusion}

99. The discussion in this chapter has underscored the need for a dedicated effort to extend to the poor the benefits of government provided public goods: to raise people out of poverty by enhancing the potential for growth. The legacy of past failures in this direction can be seen in Pakistan's social indicators, in terms of both its ranking relative to countries with comparable incomes, and the steep inequities evident across its internal rural/urban, rich/poor, and gender divides. In addition to signifying an absoiute deficit in human welfare, the poor social indicators also lower the growth potential of the economy and its ability tọ service its high debt.

100. The fact that Pakistan's economy has grown respectably in the past should not mean that these concerns are over-stated. In the light of recent experiences of slowing growth and persisting poverty, past performance in fact suggests that a certain degree of development and growth was attainable with the help of a skilled elite, unskilled workers, and a public-sector-led development strategy. However, over time this strategy ran into diminishing returns as underlying institutional problems undermined the growth in the country's aggregate stock of human capital and discouraged private investment.

101. Combined with falling growth rates, growing debt in Pakistan has also acted as a critical constraint. The decade of the 1980 s saw a rapid widening of the fiscal deficit, and as growth declined during the $1990 \mathrm{~s}$, the burden imposed by debt increased, creating a vicious cycle of falling growth rate and increasingly burdensome debt. Closing the fiscal gap must thus be a priority for public policy. That said, expenditure reductions to reduce debt must not reinforce the fiscal bias against the social sector that has contributed, in the first place, to the country's current predicament. Moreover, promoting human development, especially given the tight constraints on spending that must be imposed, will critically require improving the 
efficiency of social spending by focusing on institutional reforms that correct underlying incentives for effective service delivery.

102. This chapter has made the case for such reform by highlighting political economy factors that bave contributed to the failures of government and donor efforts in the past. The lack of accountability that undermines social and economic development can likely be improved by increased democratization, decentralization, and transparency. The ongoing devolution efforts represent significant opportumities in this direction, with the potential to create incentives for public officials that take into account broad needs, including those of women and socially disadvantaged groups. 


\section{References}

Alderman, Harold, Jooseop Kim, and Peter Orazem, 1999, "Can Private School Subsidies Increase Enrollment for the Poor? The Quetta Urban Fellowship Program," World Bank Economic Review, Vol. 13 (3).

Alderman, H., J. Hentschel, and R. Sabates, 2001, "With the Help of One's Neighbors: Extemalities in the Production of Nutrition in Peru," in forthcoming Social Science and Medicine.

Andrabi, Tahir, Jishnu Das, and Asim Khwaja, 2002, "The Rise of Private Schooling in Pakistan: Catering to the Urban Elite or Educating the Rural Poor?' background paper for Pakistan Poverty Assessment (2002), mimeo.

Barro, Robert, 1998, Cross-country determinants of growth (Cambridge: MIT Press).

Basu, K., Ambar Narayan, and Martin Ravallion, 2000, "Is Literacy Shared Within Households? Theory and Evidence for Bangladesh," Labour Economics, Vol. 8: 64965.

Drèze, J., and M. Saran, 1995, "Primary Education and Economic Development in China and India: Overview and Two Case Studies," in Choice, Welfare, and Development, ed. by K. Basu, P. K. Pattanaik, and K. Suzumura (Oxford: Clarendon Press).

Green, S. E., T. A. Rich, and E. G. Nesman, 1985, "Beyond Individual Literacy: the Role of Shared Literacy for Innovation in Guatemala," Human Organization, Vol. 44.

Easterly, William, 2001, "Pakistan's Critical Constraint: Not the Financing Gap but the Social Gap," background paper for Pakistan Poverty Assessment (2002), mimeo.

Ercelawn, Aly and S. Akbar Zaidi, 1999, "Is the Social Action Program Working? Observations from a Field Survey," in Issues in Pakistan's Economy, Appendix 18.2, Zaidi, 1999 (Karachi, Pakistan: Oxford University Press).

Filmer, Deon and Lant Pritchett, 1994, "Estimating Wealth Effects Without Expenditure Data, or Tears: an Application to Educational Enrollments in States of India," Policy Research Working Paper (Washington: World Bank)

Gazdar, Haris, 2000, “State, Community, and Universal Education: A Political Economy of Public Schooling in Rural Pakistan," Asia Research Centre (London School of Economics).

Gazdar, H., 2002, “A Qualitative Survey of Poverty in Rural Pakistan: Methodology, Data, and Main Findings," background paper for Pakistan Poverty Assessment (2002), mimeo.

Hasnain, Zahid, 2002, "Explaining Pakistan's Growth Slowdown: Fiscal Deficits, Governance, and the Social Gap," background paper for Pakistan Poverty Assessment (2002), mimeo.

Martorell, R., Schroeder, D.G., Rivera, J.A., and H.J. Kaplowitz, 1995, "Patterns of Linear 
Growth in Rural Guatemalan Adolescents and Children," Journal of Nutrition 125(4S): 1060S-1067S.

Narayan, A. and T. Vishwanath, 2001, "A Note on Education in Pakistan: Preliminary Findings from PIHS 1998-99 and Related Issue," background paper for Pakistan Poverty Assessment (2002), mimeo.

Thomas, D., V. Lavy, and J. Strauss, 1996, "Public Policy and Anthropometric Outcomes in Côte d'Tvoire," Journal of Public Economics 61: 155-192

Tinker, Anne, 1998, "Improving Women's Health in Pakistan," Human Development Network (Washington: World Bank).

World Bank, 1995, Pakistan Poverty Assessment, Report No. 14397-PAK (Washington).

World Bank, 2001, "Engendering Development: Through Gender Equality in Rights, Resources, and Voice," Policy Research Report (Oxford: Oxford University Press).

World Bank, 2001a, Reforming Punjab's Public Finances and Institutions, Report No. 2098 1-PAK (Washington).

World Bank, 2002, "Poverty in Pakistan: Vulnerabilities, Social Gaps, and Rural Dynamics," Green cover: Report No. 24296-PAK, (Washington). 
Tahle A-1 . Pakistan: Poverty Indicators for Pakistan, 1984-99

\begin{tabular}{llrrrrr}
\hline & & $1984-85$ & $1987-88$ & $1990-91$ & $1993-94$ & $1998-99$ \\
\hline & & & & & & \\
& Urban & 38.2 & 30.7 & 28.0 & 17.2 & 24.2 \\
Headcount Rate & Rural & 49.3 & 40.2 & 36.9 & 33.4 & 35.9 \\
& Overall & 46.0 & 37.4 & 34.0 & 28.6 & 32.6 \\
& & & & & & \\
& Urban & 9.2 & 6.1 & 5.7 & 3.0 & 5.0 \\
Poverty Gap & Rural & 11.9 & 8.3 & 7.8 & 6.4 & 7.9 \\
& Overall & 11.1 & 7.7 & 7.1 & 5.4 & 7.0 \\
Inequality Consumption Gini & & & & & & \\
(Per equivalent advlt consumption) & Urban & 31.4 & 31.6 & 31.6 & 30.2 & 35.3 \\
& Rural & 26.3 & 24.0 & 26.7 & 24.6 & 25.1 \\
& Overall & 28.4 & 27.0 & 28.7 & 27.6 & 29.6 \\
\hline
\end{tabular}

Sources: HIIES for years 1984-94; and PHS/HIES for 1998-99.

Table A-2. Growth in Pakistan-Last Two Decades, 1980-2000

\begin{tabular}{lcccc}
\hline & $1980-85$ & $1985-90$ & $1990-95$ & $1995-2000$ \\
\hline $\begin{array}{l}\text { Average Arnual Growth } \\
\text { of Real Per Capita GDP }\end{array}$ & 3.9 & 3.1 & 2.2 & 0.6 \\
\hline
\end{tabular}

Source: South Asia Live Database, World Bank. 


\section{Financial Sector Reforms in Pakistan ${ }^{41}$}

\section{A. Introduction}

103. Financial reforms are a key ingredient of successful economic development. A large body of research has identified the various channels through which financial sector reforms can enhance growth performance and reduce poverty. ${ }^{42}$ In particular, more efficient financial institutions and markets should contribute to higher levels of savings collection and of private investment, through the diversification of savings product and the pooling of risks. Financial reforms should also ultimately lead to improved capital allocation and higher profitability through a better dissemination of information on economic opportunity and a rationalized assessment and monitoring of investment projects. Econometric studies show a positive impact of financial deepening on economic performance in the long run. For instance, according to a recent cross-country study, a 10 percentage point increase in financial deepening (measured by credit to the private sector in percent of GDP) is likely to increase the annual growth of total factor productivity by about 0.5 percent. ${ }^{43}$ International experience suggests, however, that there is no mechanical link between credit expansion and growth. $\mathbf{A}$ precondition for a sustainable deepening of financial intermediation is the building of a strong and stable private-based financial sector that can resists shocks and strengthen confidence of depositors. Therefore, the positive impact of financial reforms may not be visible in the short-to-medium term.

104. Relying mostly on a recent in-depth study by the State Bank of Pakistan (SBP), ${ }^{44}$ this chapter will focus on Pakistan's banking sector. It will first briefly review the reforms in Pakistan during the 1990s, assess the current situation of the banking sector, analyze why the impact of the reforms has been limited so far and conclude with a discussion of present programs and policy options for further reforms. The last section is devoted to microfinance.

\section{B. A Decade of Reforms}

105. Pakistan's anthorities became aware in the late 1980s that the financial strategy pursued in the 1970s, including the full nationalization of banks, was leading the economy to a severe decline and should be reversed. Financial structural reforms were initiated in 1989 and implemented throughout the 1990s, with increasing speed after 1997. Returning to matket-based monetary and exchange rate policies and shifting from direct state

\footnotetext{
${ }^{41}$ Prepared by Jean Le Dem (MED).

${ }^{42}$ See, for instance, Levine (1997).

${ }^{43}$ Beck, Levine, and Loayza (2000).

${ }^{44}$ State Bank of Pakistan (2002). See also AsDB (forthcoming).
} 
intervention to a modem regulatory approach were the two pillars of the strategy to reform the financial sector reform. While the direction of the reforms was clear, progress was uneven, slowed down by deteriorating macroeconomic conditions, strong vested interests, the increasing cost of the reforms, and political instability. These reforms were conducted in parallel with the liberalization of the foreign exchange payment system and the introduction of market-based government debt instruments.

106. Privatization. In 1990, all banks were still state-owned. Two out of the initial five nationalized banks, Muslim Commercial Bank (MCB) and Allied Bank (ABL), were privatized in steps between 1991 and 1993, while the banking sector was steadily opened to domestic, then foreign competition. As the balance sheet of the three remaining nationalized banks deteriorated strongly, further privatization efforts became dependent on the implementation of restructuring programs, including branch closures and staff downsizing through (costly) golden handshakes. Professional management of the three nationalized banks was established in 1996. Balance of payment crises, notably in 1996 and 1998, delayed the privatization efforts, which resumed significantly only in 2000 . In 2000 , the banking sector in Pakistan consisted of 39 commercial banks totaling PRs 1,641 billion of assets, equivalent to 49 percent of GDP, with 70 percent of the banks' assets held by state-owned banks. ${ }^{45}$ The state held a participation in eight banks, of which a majority stake in three large commercial banks (Habib Bank (HB), United Bank Limited (UBL) and National Bank of Pakistan (NBP)), and a minority participation in Muslim Commercial Bank (MCB) and Allied Bank. The rest of the banking sector was about equally split between 20 foreign banks, of which three large ones (ABN-AMRO, Citibank, and Standard Chartered Bank) and 12 private domestic banks (including Union Bank). ${ }^{46}$ In September 2002, UBL was sold to a foreign group, while Habib Bank (HBL) has been brought close to the point of sale, with strategic shares to be sold to private investors by the end of $2002 .{ }^{47}$

107. Financial liberalization. Credit ceilings imposed on individual banks were gradually liberalized and eventually abolished in 1995 . They were replaced by the SBP's indirect regulation of banks' liquidity, through a system of cash reserve (CRR) and statutory liquidity

\footnotetext{
${ }^{45}$ These figures do not include a few specialized state-bwned banks, inchuding the Agricultural Development Bank of Pakistan (ADBP), the Industrial Development Bank of Pakistan (IDBP), and the SME Bank, all of which have a bank license, but are classified as NBFIs in the SBP's study.

${ }^{46}$ Banks dwarf other financial companies in Pakistan. At end-June 2000, the assets of NBFI's amounted to PRs 350 billion, about 20 percent of banks assets. NBFIs consisted of (by decreasing order): 12 development finance institutions (of which 5 have been liquidated or merged thereafter); 16 investment banks; 33 leasing companies; 41 mutual funds; 4 housing finance companies; 45 Modaraba companies (companies dealing in Islamic financing); and a few small venture capital companies and discount houses. In addition, there were 5 life-insurance companies and 50 nonlife insurers.
}

${ }^{47}$ The government shares in several banks, including UBL, HBL, and NBP, are held by the SBP, which raises a governance issue since the central bank also regulates and supervises these banks. 
requirements (SLR), ${ }^{48}$ and through the conduct of open market operations. The automatic discount window was replaced by a three-day repurchase facility in 1992. Various subsidized credit schemes were eliminated or their rates were gradually linked to market rates, including the export finance scheme in 2000. Mandatory schemes were removed except for agricultural credit. Maximum lending rates were abolished in 1995.

108. Institutional strengthening. Autonomy was gradually granted to the SBP in several steps from 1994 to 2001. Prudential regulations were issued for banks in 1992, which were made gradually compliant with the Basel Accord Core principles. Banks' minimum capital requirements were increased in 1997 and again in 2002. Starting in 1997, banking supervision was enhanced through a comprehensive set of soundness indicators and enhanced offsite and onsite inspection procedures. In 1995, nonbank financial institutions were requested to be rated by credit-rating agencies, followed by banks in 2000 . Those ratings are now regularly published on the SBP's Internet website.

109. Treatment of nonperforming loans (NPLs). Deteriorating macroeconomic conditions and political interference undermined banks' portfolios during the last decade. The size of the NPLs became clearly apparent only at the end of the decade, reflecting a gradual tightening of the regulatory framework and improved bank supervision. In 1992, the SBP strengthened guidelines for loan classification and provisioning, and requested that all loans with payments late by more than 90 days received a special mention. Stricter disclosure requirements were put in place in 1997. In response to the emergence of a large outstanding stock of bad loans and to the requirements to clean the balance sheets of state-owned banks before their privatization, the authorities gradually strengthened legal and judicial procedures, starting in 1993. In 1997, new banking courts were established and a revised recovery law was promulgated. In October 1999, an accountability and recovery drive was initiated. The Corporate and Industrial Restructuring Corporation (CIRC) was established in September 2000 as an autonomous body under the Ministry of Finance, to "promote the revitalization of the economy by reviving sick industrial units." Its main function is to recover minimum oneyear overdue loans of PRs 30 million and more on behalf of the state-owned banks and development finance institutions. As of end-June 2002, some 10.2 percent of the total stock of NPLs had been transferred to CIRC at market prices, for about 19.2 percent of their face value. CIRC has at most three years to pay for the transfer (less if the bank is privatized), partly in cash (through the liquidation of the collateralized assets), partly in five-year bonds (for the residual).

\section{Capital market reforms started in 1994 and accelerated from 1997 under a} capital market development program supported by the AsDB. The three regional stock exchanges were modernized in 1997, based on transparent regulations. An independent

\footnotetext{
${ }^{48}$ Today, (nonremunerated) statutory CRR rates amount to 5 percent of banks' Pakistani rupee dersand and time deposits. SLR rates were gradually reduced from 45 percent in 1993 to 15 percent since 1998.
} 
regulatory authority, the Securities and Exchange Commission of Pakistan (SECP) became operational in 1999. In the near future, the SBP's supervision will be limited to banks, with the SECP being the sole regulator of the nonbank financial institutions (NBFIs). The Insurance Ordinance promulgated in 2000 has started to improve the regulatory and supervisory framework in this industry, and new minimum capital requirements have been inposed, effective end-December 2002. However, several industries in the insurance and pension sectors remain dominated by inefficient state-owned near-monopolies, in particular the State Life Insurance Corporation (SLIC) and the Employees' Old-Age Benefit Institution (EOBI).

\section{A Banking Sector Assessment}

111. During recent years, the SBP has made strides toward the implementation of the Basel Core Principles for Effective Banking Supervision, and considers the financial system to be in compliance or largely in compliance with most of the 25 principles. The few remaining shortfalls include (a) that banks do not seem to have in place a comprehensive risk management process; and (b) that bank supervision is not implemented on a consolidation basis, which may affect the results for those banks having specialized subsidiaries such as Modarabas and leasing companies.

\section{Financial Soundness Indicators (FSI)}

112. Since 1997, SBP has developed a framework for assessing financial institutions' soundness based on international best practices. The framework (inspired by the Fund's CAMELS system) comprises six major areas: capital adequacy, asset quality, management soundness, earnings and profitability, liquidity, and sensitivity to market risks. The SBP has not yet compiled on an aggregate basis a capital adequacy ratio based on tier I capital nor indicators of sensitivity to market risks, such as the maturity of assets and liabilities, and the net open position in foreign exchange to capital. The indicators reviewed below are extracted from this framework and are close, although not identical, to the Fund's proposed core set of financial indicators. ${ }^{49}$

\section{Overall, the banking system in Pakistan still suffers from considerable} weaknesses (Table IV-1). Although progress has been registered in many areas, FSIs reflect adverse factors that have affected the banking system since 1998 (capital outflows and strict monetary policy to counter the exchange rate crisis) as well as genuine efforts to restructure the banking sector. Consolidated results are heavily influenced by the still predominant stateowned banks:

\footnotetext{
${ }^{45}$ Sundararajan (2002).
} 
Table IV-1. Pakistan: Selected Financial Soundness Indicators: Banking Sector, 1990-2001 1/

(In pencentage points; unjess otherwise stated)

\begin{tabular}{|c|c|c|c|c|c|c|c|c|c|c|c|c|}
\hline & 1990 & 1991 & 1992 & 1993 & 1994 & 1995 & 1996 & 1997 & 1998 & 1999 & 2000 & 2001 \\
\hline \multicolumn{13}{|l|}{$\begin{array}{l}\text { Capital adequacy } \\
\text { Bepulary }\end{array}$} \\
\hline average & n.a & n.a & n.a & n.a & n.a & n.a & n.a & 6.0 & 12.5 & 12.2 & 11.4 & 11.4 \\
\hline Number of banks below 8 percent & n.a & n.a & n.a & n.a & n.a & n.a & n.a & 5 & 0 & 1 & 3 & 4 \\
\hline \multicolumn{13}{|l|}{ Asset quality } \\
\hline NPL to total gross loans & 17.6 & 18.9 & 17.4 & 20.0 & 21.7 & 19.3 & 19.2 & 20.1 & 19.5 & 22.0 & 19.5 & 19.6 \\
\hline $\begin{array}{l}\text { Management Soundness } \\
\text { Interest rate spread }\end{array}$ & 4.0 & 4.4 & 4.4 & 4,8 & 4.6 & 4.9 & 3.8 & 5.2 & 5.3 & 5.6 & 6.4 & 5.9 \\
\hline \multicolumn{13}{|l|}{ Earnings and profitability } \\
\hline Return on Assets & 0.4 & 0.6 & 0.8 & 0.8 & 0.4 & 0.3 & 0.1 & -1.2 & 0.5 & -0.3 & 0.0 & 0.0 \\
\hline Return on Equity & 10.5 & 15.8 & 18.2 & 17.6 & 9.1 & 7.2 & 2.1 & -38.8 & 9.1 & -6.3 & -0.3 & -0.1 \\
\hline \multicolumn{13}{|l|}{ Liquidity } \\
\hline Liquid assets to total assets & 32.6 & 41.6 & 46.0 & 44.4 & 47.0 & 43.7 & 43.4 & 41.4 & 41.3 & 38.7 & 30.5 & 34.9 \\
\hline
\end{tabular}

Source : SBP

1/ Based on aggregate accounts.

2/ Difference between average income on earning assets and average cost on interest-bearing liabilities.

3/ Cash and bank balances, investment in government securities and money at call. 
- The capital adequacy ratio (measured on tier I and tier II capital) is above the 8 percent floor average. However, four banks were still below this limit in 2001-two being state-owned banks and two private domestic banks.

- The quality of assets as reported has not improved markedly (Figure IV-1): the ratio of NPL total gross is still close to 20 percent of bank credit. However, the SBP considers that the increasingly strict criteria used for assessing NPLs and more realistic reporting after 1997 may mask a substantial underlying improvement. ${ }^{50}$ Indeed, flows of new NPLs are now limited and 55 percent of the outstanding stock has already been provisioned. As of end-June 2002, two-thirds of the NPL stock was held by the nationalized banks. A sizable reduction in this stock is expected in the coming months with the transfer of nonperforming assets to CIRC that precedes the privatization of UBL and HBL.

Figure IV-1. Pakistan: Nonperforming and Default Loans as a Share of Total Gross Loans, 1990-2001.

(In percent)

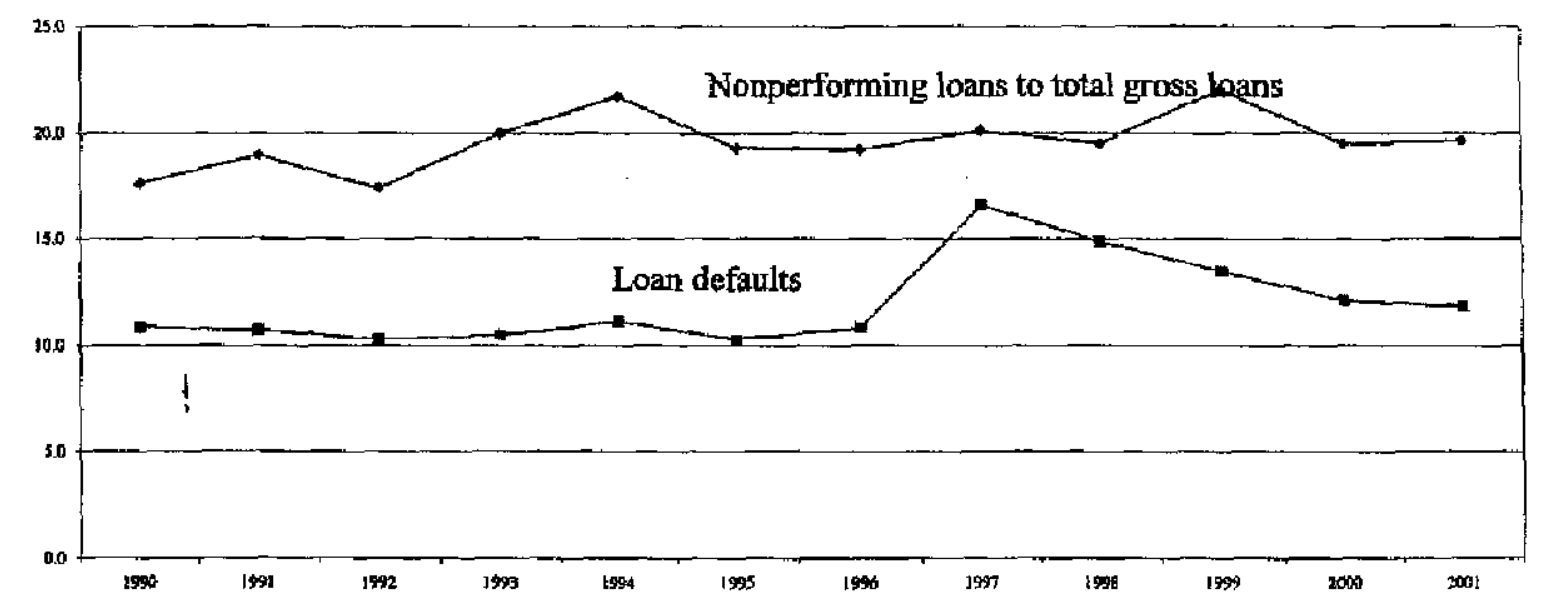

Source: State Bank of Pakistan.

- Management soundness indicators do not yet reflect much impact from the restructuring and privatization process. The spread between the average interest rate on interest-bearing assets and liabilities was on an increasing trend till recently.

${ }^{50}$ A loan will be classified as an NPL if debt service payments on this loan are overdue for 90 days, a criterion which is stricter than the one used in some neighboring countries. However, unilike in many other countries, the NPL status is not extended to other loans owed by the borrower of an NPL loan. See Prudential Regulation-VIII for banks and NBFIs for classification and provisioning, BPRD Circular No. 9, Aprid 27, 2000, on the SBP's website (www.sbp.org.pk). 
- The profitability of banks, as measured by the return on equity or the return on assets appears quite low in Pakistan, having declined since 1993. Large fluctuations in the ratios since 1996 seem to reflect mostly the entry of large provisions on NPLs, as well as the impact of the freeze on foreign currency deposits which deprived banks from a very profitable activity.

- Banks remain largely liquid, although on average less so than during the past decade. The gradual reduction in SLRs imposed on banks by the SBP, the development of banks' refinancing through the SBP's discount window and repo operations have significantly reduced banks' liquidity needs.

- The SBP has not yet developed clear indicators of sensitivity to market risks.

Exchange rate risks have probably been limited during the last decade because of various foreign exchange controls, some of which have been eliminated recently. The banks' foreign exchange open position is limited to 10 percent of capital. Up to 1997 , banks have been protected by the direct impact of large depreciations of the Pakistani rupee by forward cover provided by the SBP at a subsidized rate. Some banks may bear a significant interest rate risk on long-tern government bonds.

\section{Banks' Limited Contribution to Financial Deepening in the 1990 s}

\section{Reforms have not yet visibly improved the capacity of the banking sector to} mobilize savings, finance the private sector, and provide services at low costs.

- Financial savings as a whole increased from 45 percent of GDP in 1992/93 to more than 60 percent in 2001/02 (Figure IV-2). The increase took place mostly in three discrete steps, in 1993/94, 1997/98, and very recently. Improved confidence in the Pakistani rupee over the last year and the easing of the drives toward tax compliance and accountability initiated in 1999 encouraged the repatriation of residents' savings from abroad. However, most of the increase in financial savings was absorbed by the more attractive National Savings Schemes (NSS), which grew from 11.3 percent to 23.4 percent of GDP during the same period. Savings accumulated in banks over the same period remained mostly stable as a percentage of GDP. The dollarization of banks' deposits fluctuated largely, however. FCDs amounted to almost 30 percent of residents deposits in 1998, on account of increasing pressures on the domestic currency and incentives provided by the SBP. 
Figure IV-2. Pakistan: Stock of Financial Savings as a Share of GDP

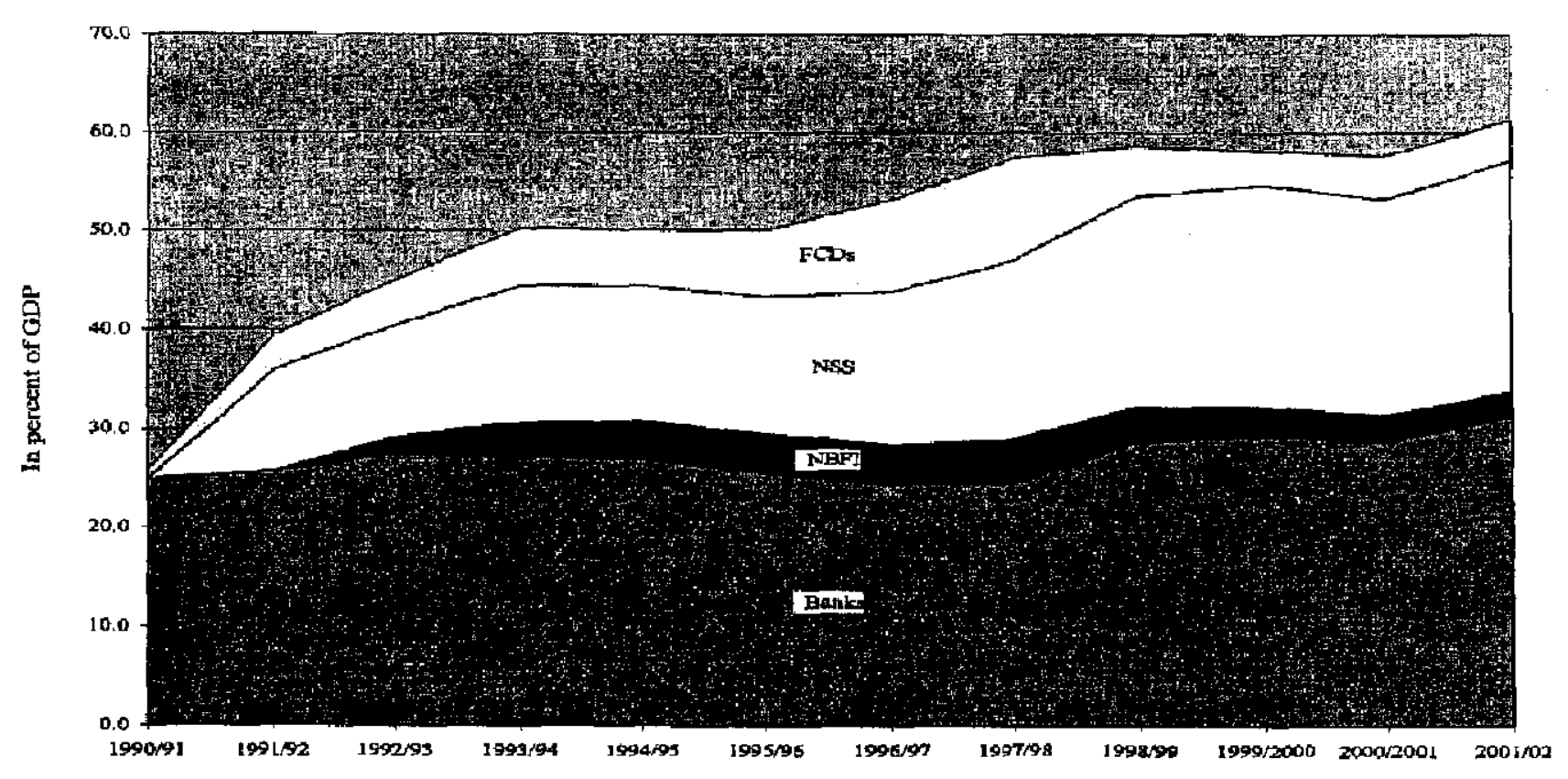

Source: State Bank of Pakistan

- Banks' contribution to the development of the private sector appears also limited (Figure IV-3). In proportion to GDP, credit to the private sector remains in the same 20-25 percent range, with a declining trend since 1998/99. The elimination of credit ceilings and constraints imposed on banks' interest rates did not boost banks' supply of credit, probably because the weight of NPLs had to be absorbed in the balance sheets, and better supervision forced banks to eliminate or reduce business with their most risky customers. The government and the public enterprises would not appear to have crowded out the private sector, since banks' credit to the public sector has declined over the last ten years. The absence of credit expansion to the private sector seems rather due to demand factors such as a lower growth overall and the decline of the private investment ratio (by about 2 percent of GDP over the last decade). Higher real interest rates offered by banks had probably also a negative contribution. 
Figure IV-3: Pakistan: Banks' Credit by Main Sector

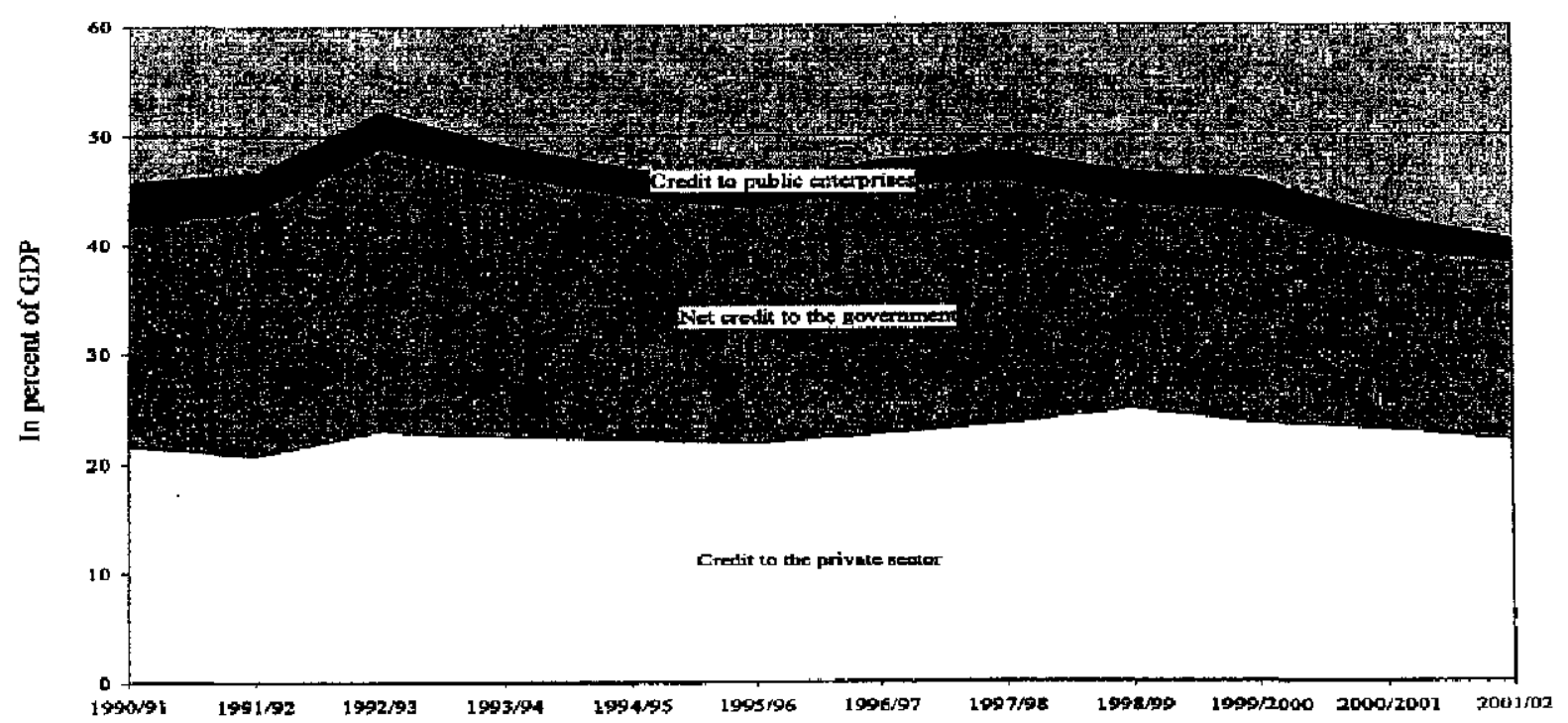

Source: State Bank of Pakistan.

- Financial liberalization has considerably increased banks' spread between average lending rates to the private sector and deposit rates, from about 2 percent in the early 1990 s, to more than 8 percent (Figure IV-4). Since then, this spread has remained high, reflecting limited competition in the banking sector, and the increasing cost of provisions on account of NPLs.

Figure IV-4: Pakistan: Spread between Average Lending and Deposit Rates

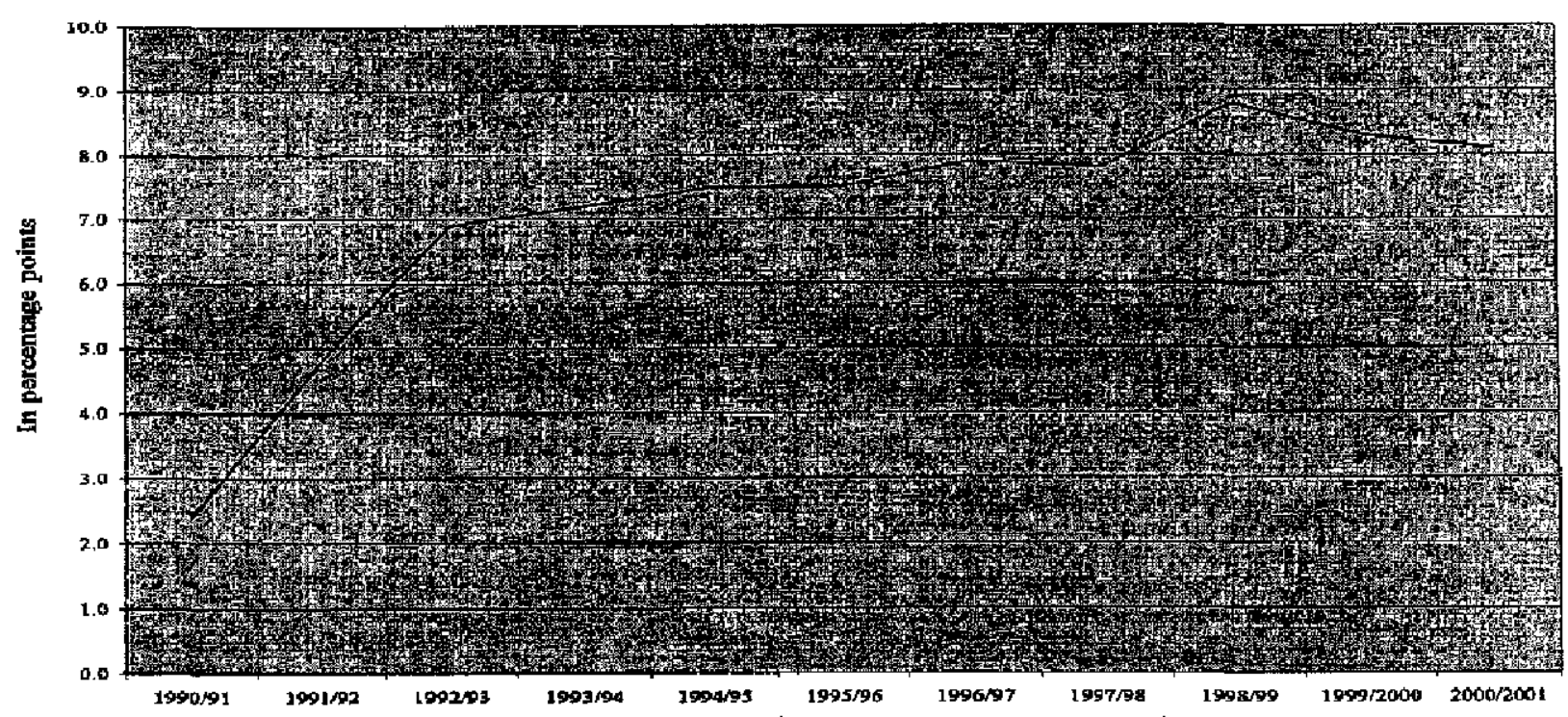

Source: State Bank of Pakistan, 


\section{E. Next Steps Toward Reform}

115. A broad-based debate has been organized by the SBP to discuss the lessons from its Financial Sector Assessment and the future reforms. In particular, a conference in June 2002 in Karachi gathered private bankers, independent observers, government officials and donors' representatives to discuss the SBP's strategy for the financial sector. The SBP's strategy and participants' reactions are analyzed below. This section concludes with additional suggestions to reform the NSS. ${ }^{51}$

\section{The SBP's strategy identifies four directions for further reforms:}

- The reshaping of the financial sector toward a three-tier structure: a first tier consisting of large universal banks; a second tier of specialized banks that would cater to specific sectoral needs or market imperfections; and a third tier of NBFIs. The implementation of this strategy would require a further restructuring and privatization of existing state-owned Development Finance Institutions (DFIs), as well as incentives for mergers and acquisitions of small and under-capitalized private banks and other financial institutions.

- An enhanced judicial, regulatory, and supervisory framework, for both banks (under the SBP) and nonbank financial institutions (under the SECP). Areas where improvements would be the most urgently needed include corporate governance in the financial sector; the quality of financial information disclosure, especially for NBFIs; improved prudential and risk management standards for NBFIs; and strengthened legal structure to facilitate foreclosure of collaterals and accelerating the recovery of bad'loans. Banks and NBFIs'supervisors need also to improve their skills.

- Improved monetary policy and interest rate market mechanisms. This will imply among other steps, more active money markets and secondary markets for government securities, as well as a further rationalization of the NSS instruments that would reduce the distortion of savings allocation as well as the interest costs of domestic debt.

- Improved supply of financial instruments and services, including exportable ones, and further development of capital markets.

117. While most participants (and the staff) had little disagreement with the SBP's directions for further reforms, the following suggestions emerged from the discussion with the financial sector stakeholders: ${ }^{52}$

\footnotetext{
${ }^{51}$ See Box 2 in EBS/02/107.

${ }^{52}$ See National Instimute of Banking and Finance (2002).
} 
The tax system and the fragmentation of financial markets. To promote a sound and large competition in the financial sector, income tax rates and withholding provisions need to be further harmonized. The tax system continues to discriminate against banks in the tax treatment of financial instruments. While income tax rates on banks have been reduced in 2002 from 58 percent to 50 percent, participants strongly supported the further steps that the authorities are considering to bring them in line with the standard corporate tax rate of 35 percent, which applies for other financial institutions such as leasing companies and investment banks, Banks' specific provisions against NPLs are not tax deductible. Withholding taxes of 20 percent on income generated by short-term treasury bills maintain an artificial bias in favor of long-term instruments. The financial component of life insurance products are subject to the General Sales Tax (GST). The Provincial and Federal Governments levy stamp duties on securities at different rates. Voluntary contributions to provident funds and pension schemes should be exempted from income tax, while annuities should be taxed. There are also tax obstacles to the mergers between banks (and other entities) that should be removed. On a related issue, private banks should be allowed to compete for operations with public enterprises, currently they are still being forced to hold accounts with nationalized banks only.

- The role of market mechanisms and sound competition in reshaping the financial sector. While market imperfections may sometimes justify government involvement, careful examination is needed before embarking in new interventionist policies. There are examples of sound practices (see the following section on microfinance) but also less convincing approaches (the restructuring of the ADBP to continue to direct credit to the agricultural sector). Some participants questioned the necessity to force mergers of small banks that are appropriately capitalized (there seems to be a positive appreciation amongst the banking profession for some small banks, which, because of a thorough knowledge of their customers, provide valuable specialized services to some niche sectors of the economy).

More efficient money and securities markets to reduce banks' intermediation costs. Day-to-day interbank rates still fluctuaie largely between SBP's interventions, generally weekly. This problem and banks' easy recourse to the SBP's repo facility do not encourage improvements in liquidity management practices. To limit the day-today volatility of short-term rates, and in particular to set a floor on overnight rates on the interbank money market, a more transparent and active monetary policy is needed. More frequent open market operations or a standing facility could signal more effectively the SBP's monetary stance. Greater predictability of short-term interest rates would permit banks to better manage their liquidity management position and would encourage them to reduce lending spreads. In this regard, the role of the SLR as a second line of defense for liquidity purposes does not seem to be consistent with the SLR-eligibility of long-term government instruments and the ineligibility of prime quality commercial paper. Specific measures are also needed to develop the secondary 
market for the new medium to long-term government bonds, the Pakistan Investment Bonds (PIBs) and for other fixed-income securities.

118. The authorities need to undertake a fundamental reform of the NSS and of the government department that issues the NSS, the Central Directorate of National Savings (CDNS). With time, the CDNS has been assigned, explicitly or implicitly, conflicting mandates: ( $\mathrm{a}$ ) design attractive savings schemes to finance the government deficit, at a time when inflation and balance of payments concerns imposed constraints on the domestic bank and foreign financing of the budget; (b) protect small savings holders from inflation and provide real income to vulnerable social groups; and (c) manage a substantial part of the government's domestic debt and minimize its cost. The performance of public entities need to be assessed against clear mandates. The only mandate which is clearly relevant for the CDNS is the management of public debt. The design of attractive savings schemes for the public would be better run by private financial institutions. NSS instruments risk to divert savings from more productive private usage, using high interest rates to attract savers at the expense of present and future taxpayers. The NSS would also seem ill-suited to serve income distribution purposes, such as supporting vulnerable social groups.

119. Some progress has been achieved to rationalize the NSS. In 2001, the authorities started to auction the PIBs, and to use them as benchmarks for NSS rates, leading to a large reduction in the cost of these schemes over the recent years. Additional nonmarket distortions have been removed through the increase in premiums for premature cashing of long-term instruments. However, the premium of NSS instruments over corresponding PIBs of the same maturity is still high enough to prevent banks from collecting significant amounts of household savings on term-deposits. In addition, the government has little choice other than to borrow through this costly on-tap instrument.

120. In the short run, NSS rates should be further reduced to put them on an equal footing with similar government instruments. In addition, the administrative costs of maintaining a retail trade system of savings collection could be passed on to NSS holders. In the medium-term, the government would have a better control of its debt management by eliminating all on-tap instruments and auctioning only a few instruments such as the treasury bills or the PIBs through primary dealers. The CDNS could progressively replace NSS instruments (starting with the most costly Defense Savings Certificates) with mutual fund instruments based on both government and private securities. Ultimately, the CDNS itself could be transformed into a private mutual fund, subject to strict prudential regulations. The authorities are considering some of these suggestions, in conjunction with a second set of financial market reforms that could be supported by the Asian Development Bank (AsDB).

121. There are no immediate plans to develop a deposit insurance scheme in Pakistan. Although mindful of the additional confidence that such a scheme would bring to the banking sector, the authorities are mostly concerned with the moral hazard issues attached to it. 


\section{F. Recent Steps Toward the Development of Financial Institutions for the Poor}

122. In Pakistan, the poor, especially in the rural areas, are underserved by existing financial institutions or have to rely on expensive informal financing. Traditional credit to the agricultural sector, including through state-owned institutions like ADBP, is barely available to poor farmers, mainly for lack of usable collaterals. Banks do not collect the savings of the poor either, especially in the rural area because of high infrastructure costs: the majority of branch closures decided recently by the major nationalized commercial banks took place in the rural sector. Alternative sources of financing are costly; annualized rates offered by informal money lenders are generally in the range of 80-120 percent, but can reach 300 percent for short-term loans. Access to tinancial services is a key component of poverty according to poverty assessments conducted in Pakistan and elsewhere. The potential demand for micro credit is huge: according to the AsDB, the 6.3 million poor households potentially represent about US $\$ 2$ billion of solvable credit demand.

123. The development of microfinance has been slow in Pakistan until recently. Traditional banks have offered limited service. The ADBP has special programs for the poor, with lirnited outreach (only 2 percent of landless farmers have ever received a loan from the ADBP). Most of these loans appear to be nonrecoverable. Some commercial banks (including the state-owned Bank of Khyber) have developed nonprofitable loan schemes in poor urban areas, mainly as a social obligation.

124. Until recently, the authorities' efforts focused on NGOs to provide microfinance to the poor. About 100 NGOs provide microfinance services to 61,200 borrowers (for a total amount of PRs 1 billion) and 417,000 depositors. Most of the NGOs that supply microfinance are government-sponsored Rural Support Programs which run grant-supported schemes. In 1997, the authorities launched a new World Bank-supported program, the Pakistan Poverty Alleviation Fund (PPAF) with an endowment of PRs 500 million to extend micro credit to 200,000 households over 4 years through 20 NGOs. Results have been disappointing in the absence of real retailing capacity from NGOs.

125. In 2000, realizing that the current microfinance schemes would not reach the poor before many years, the authorities decided to establish a new self-sustained scheme, the Khushhali Bank. The objective is to offer financial services for 10 percent of the poor over six years, of which at least 40 percent would be women. This new entity is used as an experimental tool, to test a regulatory framework that could attract new actors in the field on a sound basis. The scheme will help build a social network of community organizations that would form the basis on which lending activity could develop, supported by peer-pressure mechanisms. More affordable compared with what informal channels offer, interest rates cover the rather substantial intermediation costs of such microfinance schemes (about 10 percent), while building reserves for two funds that protect against default risks and 
insure small depositors. The infrastructure is expected to be limited to a minimum and clientoriented: mobile units visit villages to collect deposits and loan applications. The new institution is owned by private shareholders, mostly banks, and has an independent supervisory board.

126. A new legal framework for microfinance institutions (MFIs) was promulgated in 2001, to provide a legal foundation for the Khushhali Bank. Recently, a general ordinance completed the framework with regulations for new entrants. This ordinance sets up different minimum capital requirements, according to the intended coverage: respectively PRs 500 million, PRs 250 million, and PRs 100 million for national, regional, and district coverage, against PRs 1 billion for a traditional bank. It also provides a ceiling for the maximum amount of loans that a MFI can grant (US\$1,500). ${ }^{53}$ A second MFI was established in 2002, the First Microfinance Bank, sponsored by the Agha Khan foundation and the IFC.

127. Microfinance had a late but promising start in Pakistan. After two years of operation, the Khushhali Bank has very encouraging results: As of July 31, 2002, about PRs 600 million have been lent to 54,000 clients, of which 43 percent were women. So far the default rate is no more than 0.4 percent. Although the authorities have used a top-down approach to set up the bank, the promising start of this institution seems to derive from a carefully designed concept and business plan and the incorporation of lessons drawn from experience accumulated in other countries. Overhead costs have been limited to the minimum; and staff has been hired from the private sector, so that conditions have been met for the development of a for-profit sustainable institution. The initial regulatory framework had been carefully designed to match the needs of the nascent institution. This framework has been recently adjusted and will continue to evolve over time to take into account the lessons from the ongoing pilot and adapt to the needs of the expected new MFTs.

\footnotetext{
${ }^{53}$ Regulations on maximum lending rates, a well-known obstacle to the development of microfinance, have been eliminated in Pakistan in the early 1990s.
} 


\section{References}

Asian Development Bank, "Financial Sector Strategy Study," forthcoming (Islamabad).

Beck, Thorsten, Ross Levine, and Norman Loayza, 2000, "Finance and the Sources of Growth," Journal of Financial Economics, Vol.58, No.1-2, (Oct.-Nov.) pp. 261-300.

Levine, Ross, "Financial Development and Economic Growth: Views and Agenda," Journal of Economic Literature, Vol.35, No. 2, (June) pp.688-726, June 1997.

National Institute of Banking and Finance, 2002, "SBP Conference Proceedings on Financial System," conference held in Karachi June 18, 2002, (July).

State Bank of Pakistan, 2002, Financial Sector Assessment, 1990-2000, SBP Research Department (draft for discussion, available on the SBP's website at www.sbp.org.pk).

Sundararajan, et al., 2002, Financial Soundness Indicators: Analytical Aspects and Country Practices, IMF Occasional Paper No. 212 (Washington: International Monetary Fund). 


\section{DRAFT FISCAL RESPONSIBILITY AND DEBT LIMITATION ORDINANCE ${ }^{54}$}

\section{A. The Rationale for a Fiscal Responsibility Law in Pakistan}

128. Fiscal policy in Pakistan needs to be targeted at debt reduction to create room for social and development expenditures as well as to reduce fiscal vulnerabilities. The government has prepared a draft fiscal responsibility and debt limitation ordinance (henceforth draft ordinance) that sets an ambitious debt reduction target and would put in place mechanisms to achieve this target. Fiscal responsibility laws have been used successfully in many countries to limit fiscal deficits, achieve public debt sustainability, and promote prudent fiscal policies. Experience shows that fiscal transparency and reporting requirements are backbones of fiscal responsibility laws. Well-designed fiscal rules can guide policy makers in coordinating short-term and long-term objectives.

129. High prblic debt leaves Pakistan's public finances vulnerable to shocks and crowds out non-interest expenditures. In 2001/02, public debt stood at 98 percent of GDP, while interest payments accounted for 6.6 percent of GDP or almost 30 percent of public expenditure (Figure V-1). In the present environment, an exploding public debt path does not seem likely; Pakistan is projected to nun primary surpluses and nominal growth is projected to exceed the implicit interest rate on public debt. Still, sizable domestic or extemal shocks could change this outlook and eventually require large fiscal adjustment. Even if the debt dynamics are sustainable, the high cost of servicing the debt stock claims fiscal resources that are much needed in other areas. An ambitious debt reduction strategy would reduce fiscal vuinerabilities and create room for social and development spending. The strategy, however, needs to be balanced to allow for sufficient debt reduction while still providing adequate resources to other spending areas.

130. The draft ordinance requires the government to report regularly on fiscal developments and sets quantitative targets for debt reduction. The reports inform on short-term fiscal policy, including the budget and its underlying assumption, the mediumterm budget framework, and progress towards achieving the debt reduction targets. The scope of the reports goes significantly beyond existing publications and would require strong efforts at capacity building. The reports would ameliorate parliamentary and public discussion and thus contribute to informed policy making. The draft ordinance specifies a debt to GDP ratio of 60 percent as a target for $2011 / 12$ and sets a minimum debt reduction path for each fiscal year. Such a fiscal rule would constrain fiscal policy in the short-run to ensure that the debt target can be reached.

\footnotetext{
${ }^{54}$ Prepared by Axel Schimmelpfennig (FAD) with input from. Bill Allan.
} 
Figure V-1. Pakistan: Public Debt and Interest Expenditure, 1992/93-2001/02

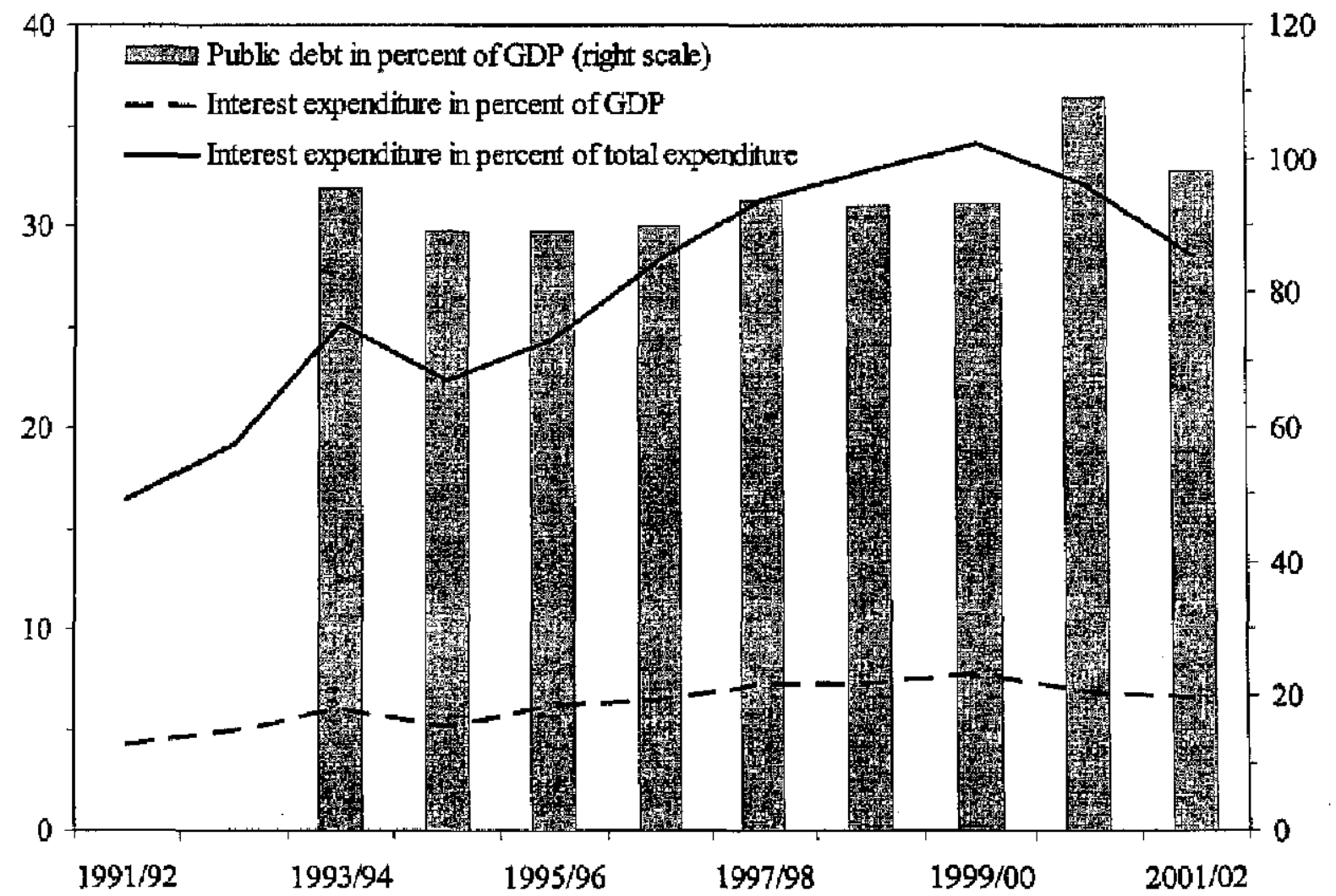

Source:_Pakistan authorities; and Fund staff calculations.

131. The draft ordinance has many of the positive characteristics shared by fiscal responsibility laws in other countries. In particular, the reporting requirements are important steps towards improving fiscal transparency, even though they may be ambitious and may not be met by the time the next budget is presented. The quantitative fiscal rules can form the basis for sustained debt reduction. They include many firewalls that serve to protect the debt reduction objective, but make the law somewhat complex. There may be scope for simplifying the rules without taking the teeth out of the draft ordinance.

132. The remainder of this note is structured as follows. Section B briefly sketches the experience with fiscal responsibility laws. Section $C$ analyzes the main elements of the fiscal responsibility and debt limitation ordinance and suggests some modifications. 


\section{B. Experience with Fiscal Responsibility Laws}

133. The experience with fiscal responsibility laws is positive. ${ }^{55}$ In some countries the focus is more on transparency, in others, the focus is more on quantitative fiscal rules that bind policy makers in their day-to-day business. Fiscal responsibility laws are typically adopted to overcome problems of deficit bias and fiscal illusion that have lead to a build-up of public debt and ultimately reduced the room for fiscal policy. Hence, fiscal responsibility laws are designed to achieve sustainable public debt levels by effectively constraining annual budgets. Transparency is an important aspect of constraining budget planning and execution because it promotes public scrutiny. Quantitative fiscal rules can provide the necessary constraints to make short-term fiscal policy consistent with long-term objectives.

\section{Some fiscal responsibility laws focus on transparency, as public debate is} thought to ensure that prudent fiscal policies will be pursued. New Zealand's 1994 Fiscal Responsibility Act mandates the government to openly discuss objectives and expected outcomes of its policies, allows for parliamentary and public assessment of fiscal policy, and strengthens reporting requirements. The Act also stipulates that governments should be judged based on their ability to reduce public debt. Australia and the United Kingdom have adopted similar fiscal responsibility acts. In none of these cases are quantitative fiscal rules included in the fiscal responsibility law. The experience with fiscal responsibility laws focusing on transparency is generally viewed positively. In fact, the MMF's Code of Good Practices on Fiscal Transparency was partly motivated by the experience of New Zealand, Australia and the United Kingdom.

\section{Quantitative fiscal rules constrain fiscal policy in the short-term to achieve a} long-term objective. Often, fiscal rules impose a ceiling on the overall deficit (e.g. the Maastricht deficit criterion), public expenditure (e.g., Sweden), or public debt (e.g., the United Kingdom's requirement to hold public debt at a stable and prudent level). Deficit and expenditure rules have the advantage of constraining policy variables that are directly related to the annual budget. However, successive ex-post deviations from a deficit or expenditure ceiling - even if only small in any given year - can undermine achieving the long-term objective. In some countries, the deficit rule applies to the current balance, defined as revenue less current expenditure. Thus, borrowing is allowed only for investment expenditure. This "golden rule" is intuitively appealing and has worked well, for example in the United Kingdom. However, golden rules can also create temptations for creative accounting that shifts current expenditure into capital expenditure. As a result, transparency would be reduced. Public debt rules do not constrain budget variables directly, but make monitoring progress towards a long-term objective of debt reduction easy. A conceptual problem with debt rules is that there is no accepted theory on what constitutes the optimal debt level.

${ }^{55}$ See Henming and Kell (2001) for a more detailed discussion. 
136. While the particnlar design of a fiscaI responsibility law will depend on countryspecific circumstances, there are some basic principles which are important across countries. ${ }^{56}$ Above all, the law should be guided by the overall long-term objective of fiscal policy. In Pakistan, this long-term objective is clearly to reduce the debt to GDP ratio to restore room for much needed social and development expenditures as well as to reduce vulnerabilities to shocks. Any fiscal nule should be clearly related to this objective and achieve it in a simple and straightforward manner. In the short-run, sufficient flexibility is needed so that fiscal policy can react to changing circumstances. Fiscal transparency, regular and open reporting on fiscal policy, objectives, and outcomes are instrumental for creating public support and can provide an enforcement mechanism through public scrutiny.

\section{The Elements of Pakistan's Draft Fiscal Responsibility and Debt Limitation Ordinance}

\section{The draft ordimance mandates the government to publish on a regular basis a} number of reports and lays out fiscal rules targeted at debt reduction over the next decade. The publication of a medium-term budget framework, annual fiscal and debt policy statements, a mid-year economic report, and an annual state of the economy report would promote fiscal transparency and constitute a strong backbone for the debt reduction strategy. The fiscal rules specify quantitative targets for the current balance (called "revenue deficit" in the Pakistani context), the annual reduction in the debt-to-GDP ratio, and the target debt-toGDP ratio by fiscal year 2011/12. An escape clause allows deviations from these quantitative targets for national security or natural calamity reasons, or in case social and poverty related expenditures are squeezed. The draft ordinance also limits the issue of new guarantees. A Debt Policy Coordination Office would assist the government in implementing the debt reduction strategy spelled out in the draft ordinance.

\section{The transparency requirements}

138. The draft ordinance requires the government to present to the National Assembly a number of reports on short-term to medium-term economic and fiscal developments. A medium-term budget statement would outline a 3-year rolling fiscal framework, projecting revenue, expenditure, deficit, public debt, and public net worth. In addition, key fiscal measures and risks to the outlook would be discussed. The annual fiscal policy statement would provide details on these aggregates for the coming fiscal year, and discuss how the budget relates to the debt reduction strategy. The fiscal policy statement would be supplemented by an annual debt policy statement which evaluates borrowing strategies, borrowing costs, and vulnerability to exchange rate movements. The debt policy statement would also analyze to what extent fiscal policy conforms with the debt reduction

\footnotetext{
${ }^{56}$ Kopits and Symansky (1998) suggest eight criteria for fiscal rules (a) well defined; (b) fiscal transparency; (c) adequate to goal; (d) intemaily consistent; (e) simplicity; (f) sufficiently flexible; (g) enforceable; and (h) supported by efficient policy actions.
} 
path and could recommend corrective actions, if these appear warranted. A mid-year economic report would update fiscal developments. The "Annual State of the Economy" report would assess the federal government's performance against its targets and the debt reduction strategy, as well as discuss major policy initiatives during the year. The reporting requirements are partly suspended, in case economic or security interest would be prejudiced, the government would be compromised in a material way, or substantial material loss to the government could ensue.

139. The reporting requirements are similar to requirements in fiscal responsibility laws in other countries, and are sound and attainable for Pakistan. Many of the provisions are aimed mainly at the federal government, but could be appropriately modified to apply for provincial governments, and perhaps even for local governments in other legislation. However, a few aspects may need to take account of Pakistan's limited capacity to implement advanced fiscal management reforms.

\section{For full compliance with the transparency requirements, fiscal projection and} reporting capacity will need to be strengthened. In particular, preparing a medium-term budget framework will require significant capacity improvements in the areas of costing and forecasting. In the context of preparing the PRSP and with international assistance, the authorities are currently seeking to enhance their capacity to produce a medium-term budget framework. Another example would be government net worth which Pakistan is unlikely to be able to report meaningfully in the near future; a comparable effort in improving data on financial and nonfinancial assets as well as liabilities would be needed for this to be achieved.

141. The fiscal responsibility law could set a path towards achleving the reporting requiremeits. Since transparency and reporting to parliament and the public is an important aspect of successful fiscal responsibility laws elsewhere, Pakistan's approach of including an extensive list of reporting requirements in the draft law is well taken. While the government may not be able to comply with some of the requirements immediately, they would still constitute desirable targets. As such, the ondinance could list those reporting requirements which apply immediately and set target dates by which other requirements have to be complied with. For example, the medium-term budget framework could be required from the $2003 / 04$ budget onward, while reporting on net wealth could be required from the 2004/05 budget on only.

142. The role of the mid-year economic report could be strengthened. It would be important that the report is focused on fiscal developments. Specifically, the report should assess to what extent budget execution is in line with the target for the fiscal year and the debt reduction strategy. If developments are found to conflict with the annual targets, corrective measures should be suggested and the government should be required to act upon these suggestions. This would strengthen the quantitative fiscal rules and limit possible slippages. 
143. The ordinance needs to be complemented by reporting requirements for provinces and local governments to the federal government. This would allow the federal government to include information on general government developments in its reports under the fiscal responsibility law. Moreover, information on provinces and local governments will become more important for analyzing fiscal developments as the devolution of responsibilities continues and provinces as well as local governments take on a larger role in the general government. The reporting requirements should be similar to the requirements for the federal government regarding fiscal developments to ensure consistency and allow consolidated general government reporting.

\section{The fiscal rules}

\section{Fiscal rules contained in the draft ordinance}

144. The draft ordinance contains three quantitative rules and two quantitative escape clauses that can be illustrated by writing down a debt dynamics equation. Letting $D$ denote public debt and $O B$ the overall balance including grants, the change in public debt is given by: ${ }^{57}$

$$
\Delta D_{t}=-O B_{t} .
$$

Expressed in percent of GDP, the change in public debt is given by:

$$
\Delta d_{t}=-\frac{g}{1+g} d_{t-1}-a b_{t},
$$

where $g$ is nominal GDP growth and lower case letters denote percent of GDP. The overall balance can be decomposed into revenue, $r$, current expenditure excluding social and poverty related expenditure, $c e$, social and poverty related expenditure, $s p$, capital expenditure, $k$, and extraordinary expenditure related to national security or natural calamity not already included in current expenditure, nse.

$$
\Delta d_{t}=-\frac{g}{1+g} d_{t-1}-\left(t_{t}-c e_{t}-s p_{t}\right)+k_{t}+n s c_{t}
$$

145. The draft ordinance specifies quantitative targets for three elements in the debt dynamies equation.

- Condition 1: Gross public debt is reduced to 60 percent of GDP by fiscal year $2011 / 12$ (i.e., $d_{2011 / 2} \leq 60$ ).

\footnotetext{
${ }^{57}$ To be precise, the equation gives the change in government net debt, defined as gross debt less financial and. nonfinancial assets.
} 
Condition 2: Gross public debt is reduced by at least 2.5 percent of GDP in each fiscal year (i.e., $\Delta d_{i} \geq 2.5$ ), unless social and poverty related expenditure fall below 4 percent of GDP (i.e., $s p_{t} \geq 4$ ).

- Condition 3: The current balance is in surplus after fiscal year 2006/07 (i.e, $\left.\left(r_{t}-c e_{t}-s p_{t}\right) \geq 0\right)$.

146. The 2011/12 debt target is not necessarily achieved by adhering to the debt reduction path of 2.5 percent per annum (Table V-1, scenario 1). For example, the projections underlying the PRGF through 2003/04 and reducing public debt by 2.5 percent of GDP from 2004/05 through 2011/12 leads to a decline in public debt to 68 percent of GDP. Assuming nominal GDP to grow at round 9 percent, this debt reduction path would be consistent with the overall deficit falling from 5 percent of GDP in 2004/05 to $31 / 2$ percent of GDP in 2011/12. To achieve the debt target of 60 percent of GDP, Pakistan would need to reduce the public debt-to-GDP ratio by 3.5 percentage points from $2004 / 05$ through $2011 / 12$ (scenario 2). This would imply that the overall deficit falls from around 4 percent of GDP in $2004 / 05$ to 2 percent of GDP in 2011/12.

147. The fiscal rules appear to allow for a loosening of fiscal policy after 2004/05. In 2003/04, the overall deficit is currently expected to be 2.4 percent of GDP under the PRGF. The overall deficit could increase to 3.7 percent of GDP in 2004/05 under the scenario in which the debt target of 60 percent of GDP is reached. It is not clear why such a loosening would be needed, unless it reflects a substitution of financing for declining grant revenue. Given Pakistan's high level of debt, it may be preferable to target an overall deficit of $2 \frac{1}{2}$ percent of GDP beyond 2003/04. Such a more conservative approach would also allow room for deviations, for example on account of the specified escape clauses, while still ensuring progress towards debt reduction over the medium term.

148. The annual debt reduction path does not necessarily need to be specified in a fiscal responsibility and debt reduction ordinance. By defining a target debt-to-GDP ratio, the required average annual debt reduction is implicitly also defined. An alternative fiscal rule could therefore simply mandate the govermment to calculate the required annual debt reduction to achieve the debt target, publish these calculations with the annual budget, and set fiscal policy accordingly. This would avoid having two quantitative targets that may not appear consistent at first sight or in every situation. However, the minimum annual debt reduction path does ensure that at least some debt reduction is achieved every fiscal year, even though this may not be enough to achieve the target by $2011 / 12$. The minimum path would then constitute a "firewall" that would likely be binding in years of low revenue and high expenditure pressures, while debt reduction would be higher in good times. To clarify this "firewall" function, it may be useful to clearly rank the different quantitative criteria to rule out any scope for interpretation. 
Table V-1. Pakistan: Debt Reduction Scenarios, 2001/02-2011/12

(In percent of GDP; unless otherwise indicated)

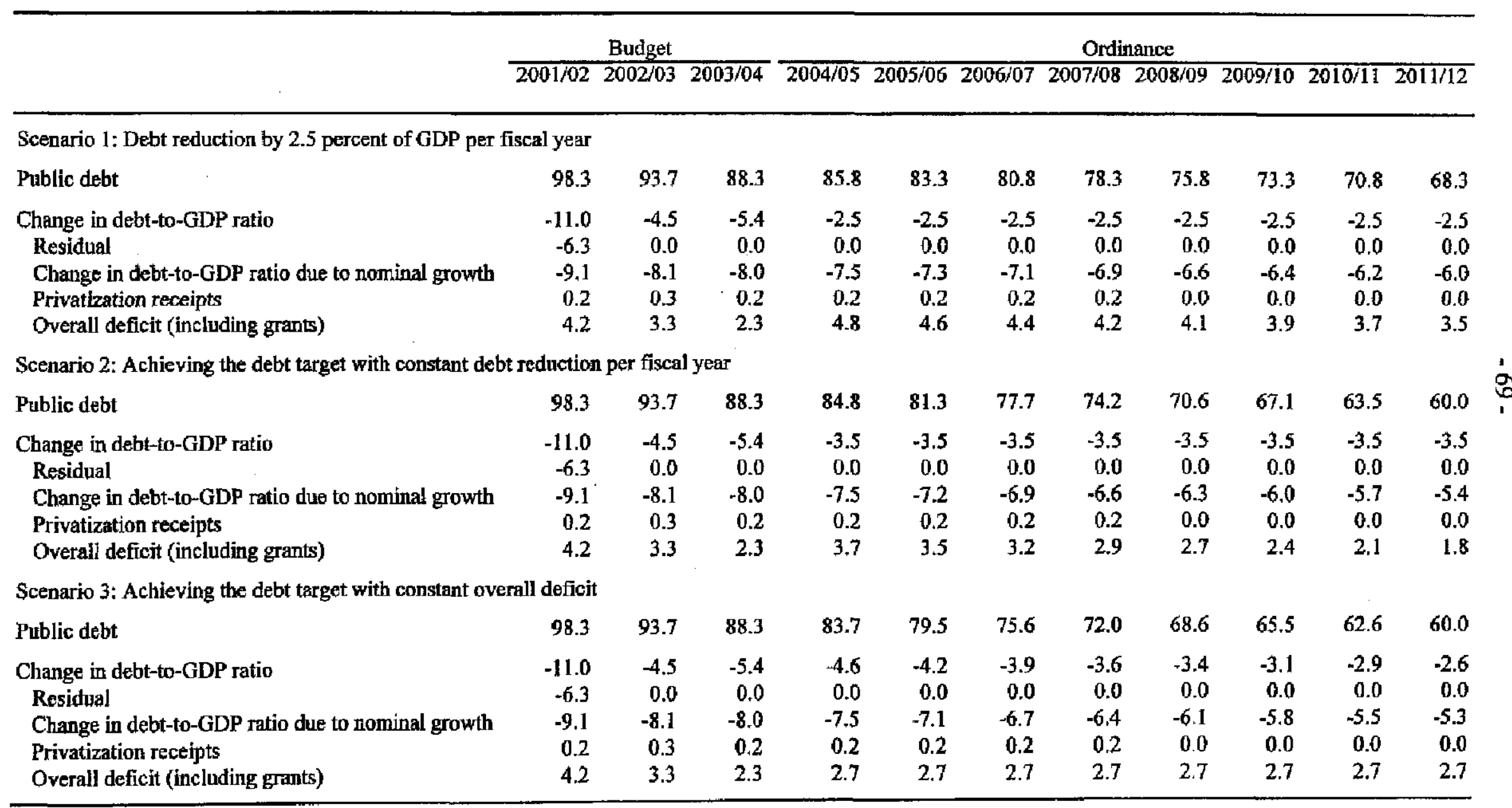

Source: Pakistani authorities; and Fund staff calculations and estimations. 
149. The current balance requirement can help strengthen fiscal prudence, though it is not needed for debt reduction. Debt reduction would already have been achieved through adhering to the debt reduction target and/or the debt reduction path. However, the debt reduction path allows for contracting new debt, though at a slow pace so that the debt to GDP ratio is reduced as Pakistan effectively grows itself out of debt. In this context, the current balance requirement would ensure that new debt is contracted only for the public sector development program (PSDP). The requirement thus adds a constraint on expenditure composition within a given debt reduction path. At the same time, the debt reduction path puts effectively an upper limit on PSDP expenditure given nominal GDP growth. In 2001/02, the current deficit-defined as revenue excluding grants less current expenditure-was 2 percent of GDP. For 2002/03, the current deficit is projected at 1.2 percent. Since the overall deficit can even be loosened somewhat under the debt reduction strategy, achieving current balance by $2006 / 07$ implies a reallocation from current expenditure to the PSDP.

150. Achieving current balance or surplus is not fully equivalent to a "golden-rule" in the case of Pakistan. Since the PSDP contains some current expenditure items, curtent balance does not imply that borrowing is for investment purposes only. Of course, the definition of what constitutes investment is not clear cut. For example, the Lady Health worker program, which is included in the PSDP, would most likely be classified as current expenditure according to the Government Finance Statistics standard, though there is little doubt that spending on health and education can have an investment quality, in particular in developing countries. These considerations do not suggest that targeting current balance cannot be a useful approach, they merely highlight the concept's ambivalence.

151. The escape clause for social and poverty expenditure could undermine the draft ordinance's main objective. Certainly, social and poverty expenditure deserves special attention in the case of Pakistan and should be protected. Nevertheless, by having an escapeclause for a particular spending category, the need to prioritize expenditures within a given resource envelope would be weakened. Onfy the resource envelope should follow from the ordinance, calculated from the debt reduction target, revenue projections, and growth projections. The composition of expenditure would then be decided through the budget process. Commitments on social and poverty related expenditure should be reflected in the budget process which will have to arrive at the hard choices on how to allocate the overall envelope between competing objectives.

\section{As an ex-post adjustor, the escape-clause for national security or natural} calamity reasons would allow some flexiblity in the debt reduction framework. In the case of unforeseen events relating to national security or natural disasters, it may be reasonable to deviate temporarily from the long-term strategy. This would, for example, be consistent with the tax-smoothing literature. The ordinance could explicitly provide for such emergencies and allow an ex-post deviation from the debt reduction path. Thus, if an unforeseen emergency occurs during a fiscal year, a lower than budgeted debt reduction on account of expenditures relating to the emergency would not constitute a violation of the ordinance. However, as argued above in the case of social and poverty expenditure, the 
ordinance should not allow for deviations from the debt reduction path on account of expenditure pressures that are aiready known at the time of the budget (i.e., ex-ante). If including such an ex-post escape clause, the ordinance should also specify how to proceed after a one-off deviation. Either, the ordinance could require that the missed debt reduction be made up in subsequent years, or the ordinance could suggest that the debt target be adjusted accordingly. To avoid that a number of subsequent one-off deviations derail the debt reduction process, it may be preferable to mandate that the slippage be offset over the next two fiscal years.

153. The draft ordinance also puts a limit on issuing public guarantees per fiscal year of 2 percent of GDP. Renewal of existing guarantees would be counted against the limit. In addition, the present value of payments for guaranteed rates of return, output purchase agreements, and other claims and commitments over the next five years would also be counted against the limit. The limit on public guarantees reduces the scope for evading the fiscal responsibility law by issuing guarantees rather than financing programs within the budiget. Moreover, the limit ensures that the risks to the debt reduction process from called guarantees is bounded. Public guarantees should be reported as contingent liabilities when assessing the debt reduction path. Since public guarantees are a contingent liability which are debt creating when called, the amount of outstanding and new guarantees should be considered when determining the debt reduction patb. Over the last decade, the government has issued guarantees each fiscal year ranging from 0.2 percent to 1.2 percent of GDP. Guarantees were extended, for example, for WAPDA and KESC borrowing, as well as for commodity operations; during this fiscal year, Pakistan International Airline (PIA) will receive guarantees for loans taken to finance its fleet renewal.

154. The ordinance could lay out a vision for fiscal policy after the debt target has been achieved. Such a vision could simply set the limit on public debt in percent of GDP equal to the debt target beyond the target date. Thus, public debt should be kept at or below 60 percent of GDP after reaching this target in 2011/12. Alternatively, the ordinance could require the debt target to be revisited to take account of any developments that could influence the choice of a maximum debt to GDP ratio.

155. Fiscal rules for provinces and local governments should be developed as well. As fiscal devolution proceeds, the federal government will lose some control over macroeconomic fiscal policy and public-debt accumulation to provinces and local governments. Hence, limiting federal government debt may not suffice to achieve debt sustainability and regain room for non-interest expenditure. A balanced budget requirement for provinces and local governments would address this issue. While more complex rules are conceivable, they would likely strain implementation capacity and would be fairly difficult to monitor by the legislative and the public at large.

156. The draft ordinance does not fully specify whether the fiscal rules apply ex-ante or ex-post. On the one side, the rules would clearly need to be considered for the annual budget. On the other side, the draft ordinance includes sanctions, if the rules are violated two 
years in a row, suggesting that the rules also apply ex-post. Since nominal GDP growth which is beyond the government's control contributes to debt reduction, applying the draft ordinance's rules as ex-post rules may not be feasible. In particular, the draft ordinance would have to define whether sanctions apply only if the deviation from the rules is due to policy failure or whether they apply independent of the source of deviation. As these requirements would certainly add to the ordinance's complexity, a more simple approach may be preferred.

157. The fiscal rules should be ex-ante rules. The rules would determine the general framework with which the annual budget would have to comply. In fact, the ordinance could rule that any budget that does not comply with the ordinance's rules and objectives is void and does not have the force of law. Ex-post deviations from the rules should trigger automatic adjustment going forward. This would ensure that past deviations do not accumulate and derail progress towards meeting the debt target.

\section{The ordinance's sanctions for noncompliance with the rules may not be} practical. It would often be difficult to determine whether the rules have been violated since the final budget outcome data are available only with a significant lag. Hence, sanctions could not be imposed immediately, but possibly only one or two years after the effect. However, in many countries, parliamentary and public scrutiny have proved to be an effective sanctioning mechanism. With the government being required to provide detailed reports on its performance against the ordinance's rules, this sanctioning mechanism should prove forceful in Pakistan as well.

\section{Possible alternative fiscal rules}

\section{The draft ordinance has several targets relating to debt reduction, expenditure} composition, and guarantees. It would appear that the debt target for $2011 / 12$ is the central objective and the other targets could be viewed as supporting elements. In this case, two simpler alternative rules could be considered. Both alternatives would take the debt target as the central objective and specify a fiscal rule for annual fiscal targets that would ensure the debt reduction required to achieve the debt target. One alternative would have the fiscal rule set a path for the overall deficit. The other alternative would have the fiscal rule set a ceiling on expenditures. The resulting debt reduction path as well as the implicit path for the fiscal targets should be smooth rather than back loaded to ensure that it can be achieved in an orderly manner without requiring excessive adjustment as the target date approaches. Moreover, a smooth debt-reduction path spreads the burden of fiscal restraint over successive governments and avoids giving early governments an easy way out.

\section{The fiscal rule could set an annual floor for the overall balance consistent with} the debt target. Two ways to determine the annual floor for the overall balance consistent with the debt target could be considered. First, the annual debt reduction in percent of GDP can be held constant (scenario 2). The floor on the overall balance then follows by subtracting the projected growth effect from the debt reduction. Second, the floor on the overall balance in percent of GDP can be held constant (scenario 3). The annual debt reduction in percent of 
GDP then follows by adding the projected growth effect to the overall balance. An argument for the second approach is that a smooth overall balance path is appropriate for short-term demand management purposes. Moreover, this would spread the burden of fiscal restraint over all govermments.

161. The annual floor on the overall balance floor should be adjusted, if actual debt reduction falls short of the debt reduction target in any given year. If the debt reduction falls short of target because growth was lower than expected, a revised constant floor for the overall balance would be calculated. This amounts to updating the fiscal rule every year in order to ensure that past shortfalls beyond the government's control do not threaten the debt target. If the debt reduction falls short of target because of policy slippages, the shortfall should be made up by raising the floor for the overall balance in the two following fiscal years accordingly. Likewise, shortfalls due to an escape clause should be made up through adjustment of the annual floor on the overall balance.

\section{Another alternative would be an expenditure rule consistent with the debt} reduction target, which could give some more flexibility than an overall balance floor. The expenditure rule would derive an expenditure ceiling based on the overall balance necessary to achieve the debt reduction target and revenue projections. This framework would allow for some cyclical fluctuations on account of automatic stabilizers on the revenue side. Some countries have found expenditure rules effective in bringing about fiscal consolidation because they stress the resource constraint within which the budget process has to set expenditure priorities. In addition, expenditure nules can be effective in containing expenditure pressures in the course of the fiscal year. The expenditure rale should compensate any past deviation from the debt reduction path on account of revenue shortfails in a fiscal year via an explicit link to the debt target ${ }^{58}$ This mechanism would also claw back any shortfalls on the debt reduction path on account of overoptimistic revenue projections.

\section{The debt target should be set sufficiently ambitious, while also allowing} resources for social and development expenditures. By explicitly designing the debt target with the resource needs for social and development expenditures in mind, an escape clause to protect these expenditures would not be necessary. Based on broad long-term revenue and expenditure projections, the scope for debt reduction in Pakistan can be gauged. On current trends, while allowing for some increase in I-PRSP expenditure to around 5 percent of GDP as well as in the PSDP to around $4 \frac{1}{2}$ percent of GDP, the debt target of 60 percent of GDP by 2011/12 appears within reach, if growth remains strong. While this exercise seems to duplicate the fiscal rule, the two should not be confiused. The rough calculations serve to

\footnotetext{
${ }^{5 B}$ See Daminger (2002) for such an expenditure rule.
} 
check whether a debt reduction target is reasonable. The fiscal rule would take the debt target as given and then generate an overall balance or expenditure path accordingly. Decisions on revenue and expenditure policies would then be made in the budget process subject to the fiscal rule.

\section{The role of the debt policy coordination office}

\section{The debt policy coordination office would set the broad macroeconomic fiscal} targets by preparing the medium-term budget statement and the debt reduction path. The government would have to follow the principles laid out by the debt office. In addition, the office would draft the debt policy statement and advice on the debt management strategy. The office would report directly to the minister of finance.

\section{The idea of a debt council or an independent fiscal councils is controversial in} the literature. On the one side, having an independent fiscal council is thought to take the politics out of fiscal policy similar to the approach to monetary policy. Hence, independent fiscal councils are intended to overcome political economy problems of fiscal illusion and deficit bias. Based on technocratic reasoning, the independent fiscal council would set the macroeconomic parameters for fiscal policy and ultimately achieve a sustainable level of public debt. ${ }^{59}$ On the other side, fiscal policy has direct implications for allocation and distribution and it is not clear whether such decisions should be taken outside the realm of politics by appointed technocrats (cf. Hemming and Kell 2001). In the case of Pakistan, an independent fiscal council may not be needed because the draft ordinance already spells out fiscal rules that determine a debt reduction path. This in itself sets the macroeconomic fiscal background with which the annual budget and the medium-term budget framework have to comply. :

\section{Several functions assigned to the debt office have to be carried out by a} dedicated unit in the ministry of finance. For example, the debt reduction path consistent with the debt target needs to be calculated and the medium-term budget framework which is consistent with that path needs to be prepared. Also, debt management capacity could be further developed to minimize borrowing costs and vulnerabilities associated with public debt. In this regard, a debt policy coordination office or a fiscal responsibility law secretariat could play a useful and critical role. However, the focus should be on strengthening the macrofiscal management capacity within the ministry of finance and improve the quality and public accessibility of fiscal policy and debt strategy statements. While these tasks could be taken on by a dedicated office, they could also be incorporated in the existing organizational structure, for example in the budget wing.

\footnotetext{
${ }^{59}$ In the literature, this discussion is often framed in the context of stabilization policy in advanced economies. See for example Blinder (1997) and von Hagen and Harden (1994).
} 


\section{References}

Blinder, Alan S. (1997), "Is Government Too Political?" in: Foreign Affairs, November/December, pp. 115-126.

Danninger, Stephan (2002), "A New Rule: 'The Swiss Debt Brake"' IMF Working Paper 02/18 (Washington; International Monetary Fund).

Hemming, Richard and Michael Kell (2001), "Promoting Fiscal ResponsibilityTransparency, Rules and Independent Fiscal Authorities", Banca d'Italia.

Kopits, George, and Steven Symansky (1998), Fiscal Policy Rules, International Monetary Fund Occasional Paper No. 162, Washington, DC.

von Hagen, Jürgen and lan J. Harden (1994), "National Budget Processes and Fiscal Performance", in: European Economy, No. 3. 
Table 1. Pakistan: Sectoral Origin of Gross Domestic Product, 1997/98-2001/02

(At 1980/81 constamt prices)

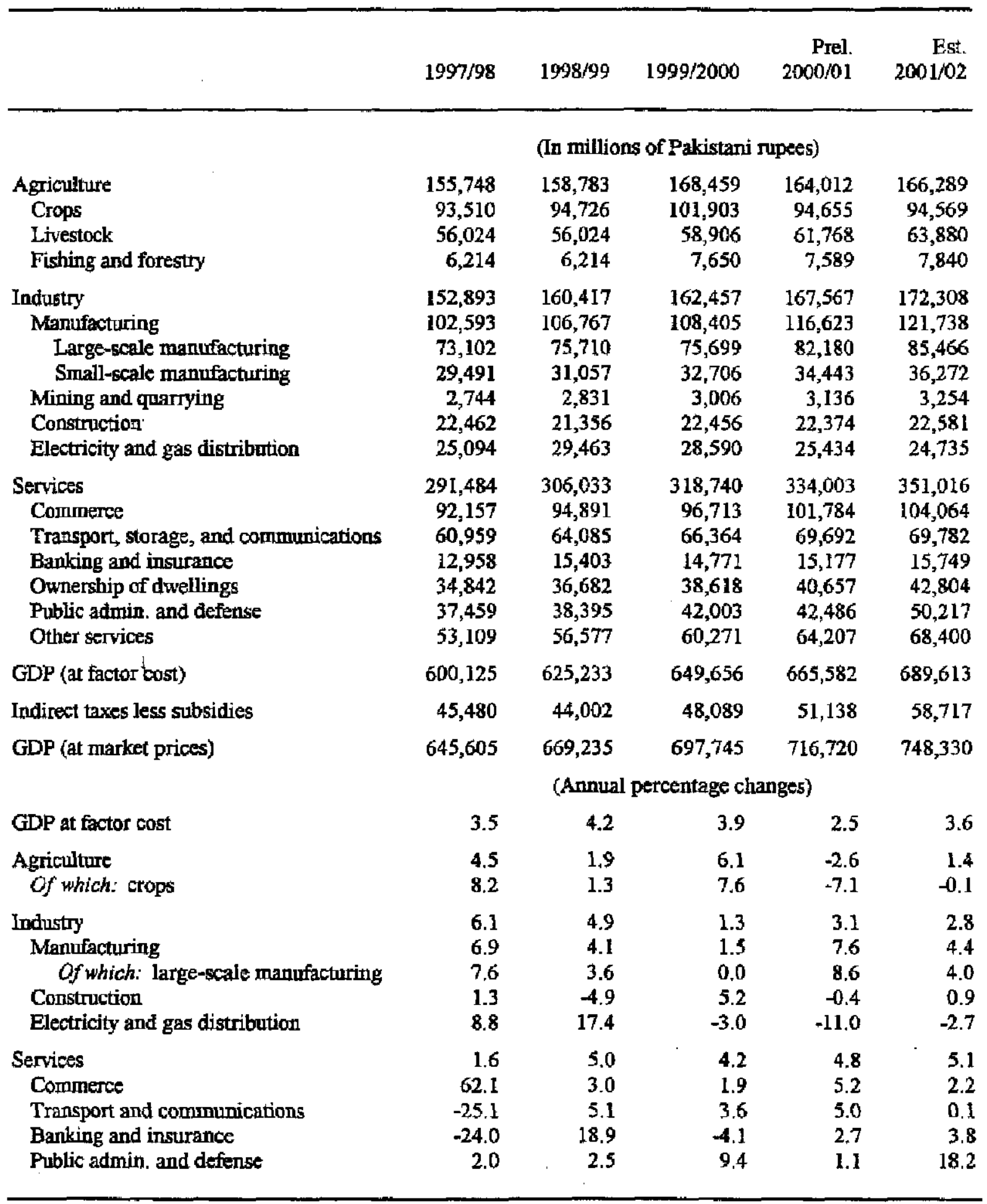

Source: Federal Burean of Statistics. 
Table 2. Pakistan: Sectoral Origin of Gross Domestic Product, 1997/98-2001/02

(At current prices)

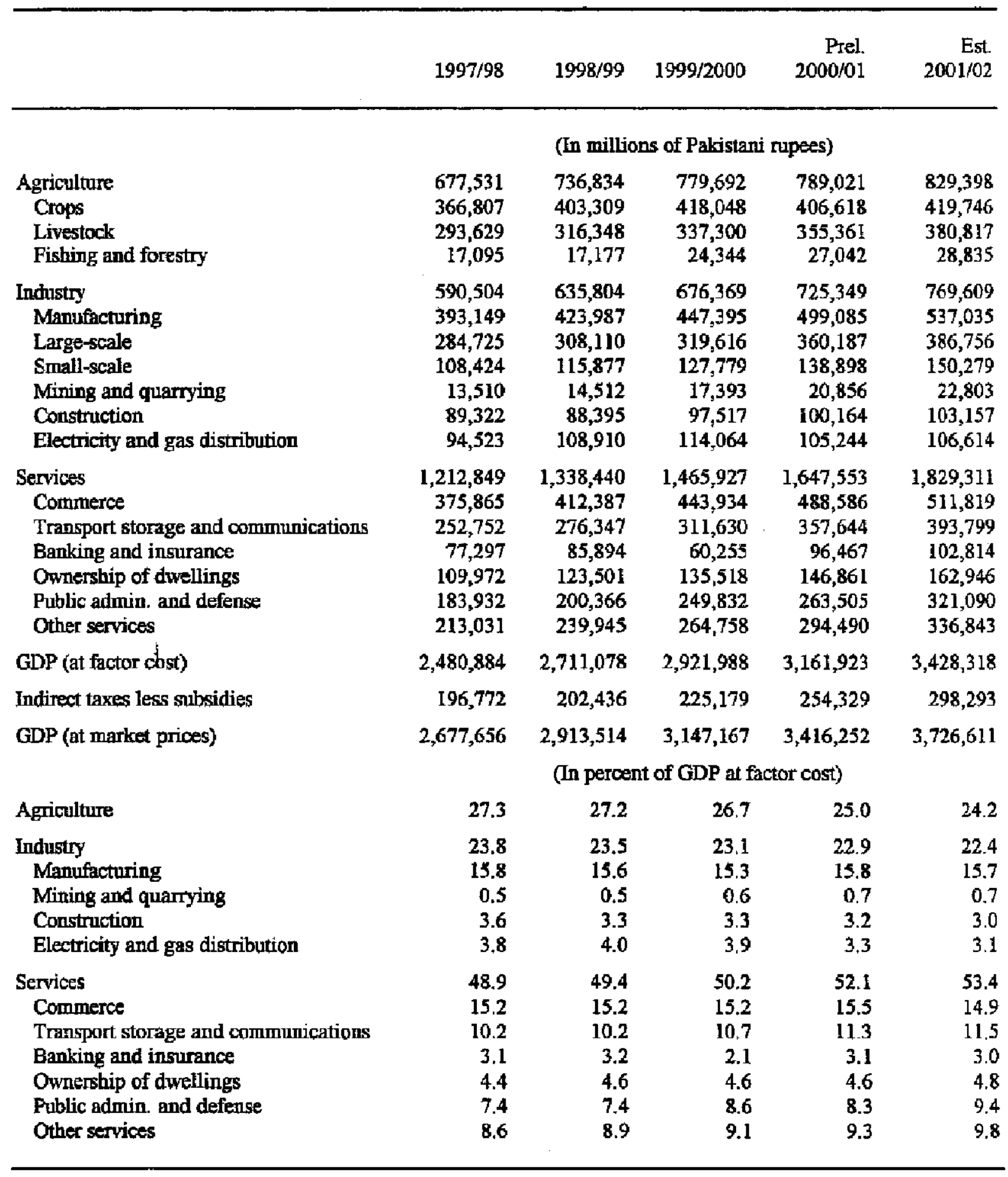

Source: Federal Bureau of Statistics. 
Table 3. Pakistan: Expenditure and Savings, 1997/98-2001/02

(At current prices)

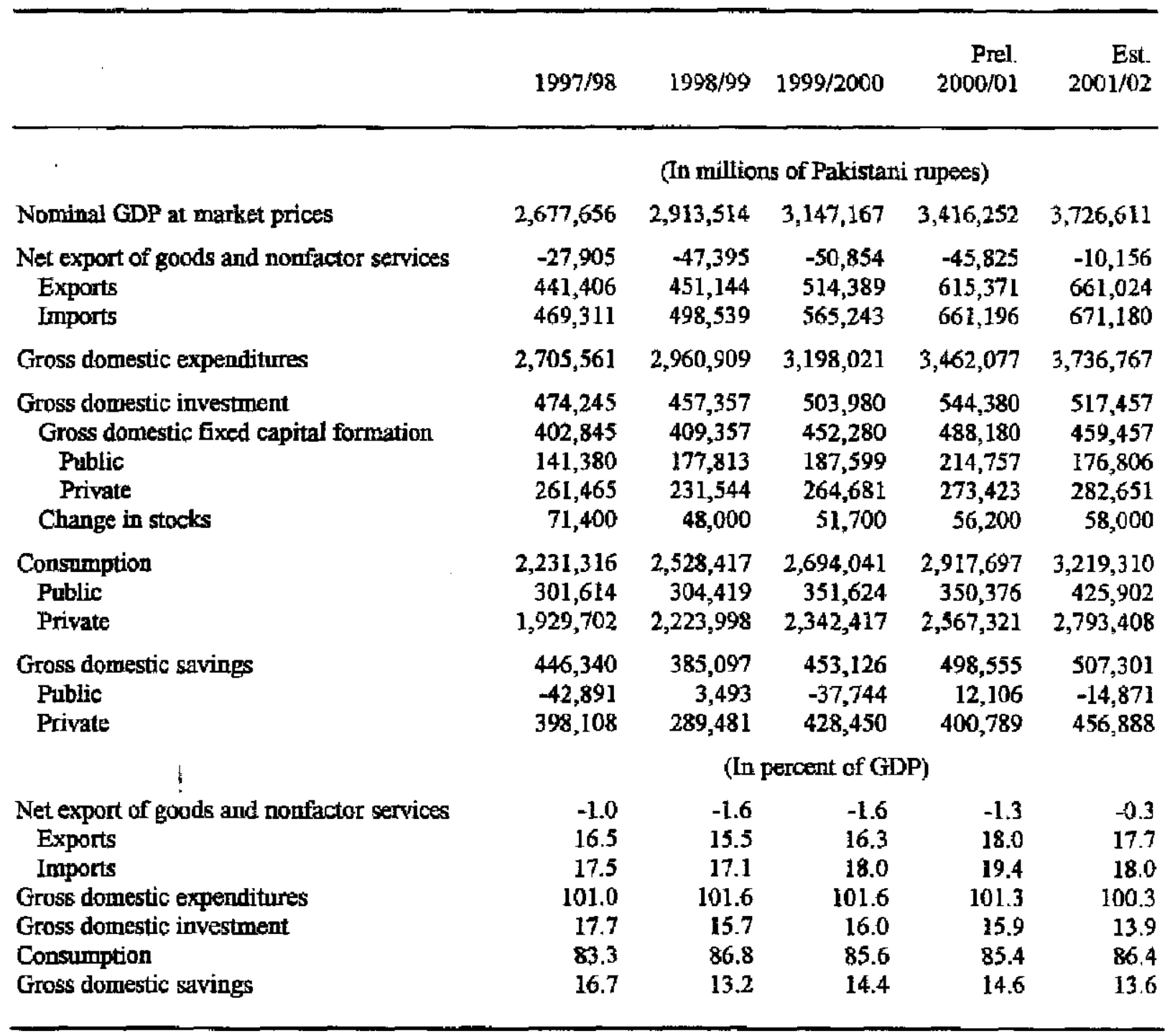

Source: Federal Bureau of Statistics 
Table 4. Pakistan: Gross Fixed Capital Formation by Economic Sector, 1997/98-2001/02

\begin{tabular}{|c|c|c|c|c|c|}
\hline & $1997 / 98$ & $1998 / 99$ & $999 / 2000$ & $\begin{array}{r}\text { Prel. } \\
2000 / 01\end{array}$ & $\begin{array}{r}\text { Est } \\
2001 / 02\end{array}$ \\
\hline & \multicolumn{5}{|c|}{ (In millions of Pakistani rupees) } \\
\hline Private sector & 261,465 & 231,544 & 264,681 & 273,423 & 282,651 \\
\hline Agriculture & 21,419 & 26,968 & 30,885 & 29,909 & 25,718 \\
\hline Mining and quarrying & 5,247 & 6,582 & 5,756 & 6,293 & 6,510 \\
\hline Large-scale manufacturing & 49,897 & 41,955 & 59,690 & 64,240 & 59,939 \\
\hline Small-scale manufacturing & 15,145 & 17,941 & 18,039 & 19,796 & 21,439 \\
\hline Construction & 12,073 & 9,617 & 11,886 & 14,957 & 19,312 \\
\hline Electricity and gas & 40,373 & 14,349 & 13,352 & 10,632 & 17,083 \\
\hline Transport and communications & 33,187 & 22,269 & 28,125 & 27,977 & 23,002 \\
\hline Banking, insurance, and other financial institutions & 5,625 & 7,602 & 6,562 & 2,907 & 6,435 \\
\hline Ownership of dwellings & 49,182 & 53,200 & 56,309 & 59,935 & 63,419 \\
\hline Wholesale and retail trade and other services & 29,317 & 31,061 & 34,077 & 36,777 & 39,794 \\
\hline Public sector & 141,380 & 177,813 & 187,599 & 214,757 & 176,806 \\
\hline Public sector enterprises & 81,802 & 115,621 & 122,919 & 147,773 & 105,531 \\
\hline Agriculture & 3,482 & 5,474 & 2,921 & 875 & 3,819 \\
\hline Mining and quarrying & 5,774 & 3,772 & 2,649 & 3,474 & 3,837 \\
\hline Mamufacturing & 5,345 & 34,480 & 24,998 & 53,587 & 5,988 \\
\hline Construction & 4,268 & 3,298 & 2,743 & 4,108 & 4,199 \\
\hline Electricity and gas & 26,181 & 26,613 & 36,963 & 34,155 & 30,739 \\
\hline Transport and communications & 30,140 & 36,385 & 47,653 & 44,488 & 45,052 \\
\hline Railway & 2,219 & 3,450 & 457 & 3,180 & 6,369 \\
\hline Post office, telegraph, and telephone & 9,921 & 13,326 & 19,761 & 19,261 & 16,544 \\
\hline Others & 18,000 & 19,609 & 27,435 & 22,047 & 22,139 \\
\hline Wholesale and retail trade & 0 & 2 & 0 & 0 & 0 \\
\hline Finançial institutions & 1,739 & 2,275 & 2,123 & 2,738 & 2,766 \\
\hline Services & 4,873 & 3,322 & 2,869 & 4,348 & 9,131 \\
\hline General government & 59,578 & 62,192 & 64,680 & 66,984 & 71,275 \\
\hline Federal & 23,773 & 24,351 & 24,966 & 24,029 & 24,210 \\
\hline Provincial & 27,824 & 29,081 & 30,708 & 31,369 & 35,084 \\
\hline \multirow[t]{2}{*}{ Local bodies } & 7,981 & 8,760 & 9,006 & 11,586 & 11,981 \\
\hline & \multicolumn{5}{|c|}{ (Annual changes in percent) } \\
\hline $\begin{array}{l}\text { Private sector } \\
\text { Of which: }\end{array}$ & 12.8 & -11.4 & 14.3 & 3.3 & 3.4 \\
\hline Agriculture & 6.8 & 25.9 & 14.5 & -3.2 & -14.0 \\
\hline Large-scale mamufacturing & -3.6 & -15.9 & 42.3 & 7.6 & -6.7 \\
\hline Small-scale manufacturing & 6.4 & 18.5 & 0.5 & 9.7 & 8.3 \\
\hline Construction & 12.6 & -20.3 & 23.6 & 25.8 & 29.1 \\
\hline Transport and communications & 41.6 & -32.9 & 26.3 & -0.5 & -17.8 \\
\hline Ownership of dwellings & 9.5 & 8.2 & 5,8 & 6.4 & 5.8 \\
\hline Public sector & -14.8 & 25.8 & 5.5 & 14.5 & -17.7 \\
\hline Public sector enterprises & -27.7 & 41.3 & 6.3 & 20.2 & -28.6 \\
\hline Of which: & & & & & \\
\hline Electricity and gas & -19.6 & 1.7 & 38.9 & -7.6 & -10.0 \\
\hline Transport and communications & -35.1 & 20.7 & 31.0 & -6.6 & 1.3 \\
\hline General government & 12.8 & 4.4 & 4.0 & 3.6 & 6.4 \\
\hline
\end{tabular}

Sourc: Federal Bureau of Statistics. 
Table 5. Pakistan: Production of Major Crops, 1997/98-2001/02

\begin{tabular}{lrrrrr}
\hline & & & & Prel. \\
& $1997 / 98$ & $1998 / 99$ & $1999 / 2000$ & $2000 / 01$ & $2001 / 02$ \\
\hline \multicolumn{5}{c}{ (In thousand of metric tons; unless otherwise specified) } \\
Cotton 1/ & 9,184 & 8,790 & 11,240 & 10,732 & 10,613 \\
Wheat & 18,694 & 17,858 & 21,079 & 19,024 & 18,475 \\
Rice & 4,333 & 4,674 & 5,156 & 4,803 & 3,882 \\
Sugarcane & 53,104 & 55,191 & 46,333 & 43,606 & 48,042 \\
& & $($ Arnual changes in percent) & & \\
Cotton & -2.0 & -4.3 & 27.9 & -4.5 & -1.1 \\
Wheat & 12.3 & -4.5 & 18.0 & -9.7 & -2.9 \\
Rice & 0.7 & 7.9 & 10.3 & -6.8 & -19.2 \\
Sugarcane & 26.4 & 3.9 & -16.0 & -5.9 & 10.2 \\
\hline
\end{tabular}

Source: Ministry of Food, Agriculture, and Livestock

1/ In thousands of bales. 
Table 6. Pakistan: Area, Production, and Yield of Major Crops, 1997/98-2001/02

\begin{tabular}{|c|c|c|c|c|c|}
\hline & $1997 / 98$ & $1998 / 99$ & $1999 / 2000$ & $2000 / 01$ & $\begin{array}{r}\text { Prel. } \\
2001 / 02\end{array}$ \\
\hline \multicolumn{6}{|l|}{ Vheat } \\
\hline Production (thousand metric tons) & 18,694 & 17,858 & 21,079 & 19,024 & 18,475 \\
\hline Area (thousand hectares) & 8,355 & 8,230 & 8,463 & 8,181 & 7,984 \\
\hline Yield (kilograms per hectares) & 2,237 & 2,170 & 2,491 & 2,325 & 2,314 \\
\hline \multicolumn{6}{|l|}{ Rice } \\
\hline Production (thousand metric tons) & 4,333 & 4,674 & 5,156 & 4,803 & 3,882 \\
\hline Area (thousand hectares) & 2,317 & 2,424 & 2,515 & 2,377 & 2,114 \\
\hline Yield (kilograms per hectares) & 1,870 & 1,928 & 2,050 & 2,021 & 1,836 \\
\hline \multicolumn{6}{|l|}{ Cotton (int) } \\
\hline Production (thousand bales) & 9,184 & 8,790 & 11,240 & 10,732 & 10,613 \\
\hline Area (thousand hectares) & 2,960 & 2,923 & 2,983 & 2,928 & 3,116 \\
\hline Yield (kilograms per hectares) & 528 & 512 & 641 & 624 & 579 \\
\hline \multicolumn{6}{|l|}{ Sugarcane } \\
\hline Production (thousand metric tons) & 53,104 & 55,191 & 46,333 & 43,606 & 48,042 \\
\hline Area (thousand hectares) & 1,056 & 1,155 & 1,010 & 961 & 1,000 \\
\hline Yield (kilograms per hectares) & 50,279 & 47,780 & 45,883 & 45,385 & 48,056 \\
\hline
\end{tabular}

Source: Ministry of Food, Agriculture, and Livestock. 
Table 7. Pakistan: Output in Selected Industries, 1997/98-2001/02

(In thousands of metric tons; unless otherwise specified)

\begin{tabular}{|c|c|c|c|c|c|}
\hline & $1997 / 98$ & $1998 / 99$ & $1999 / 2000$ & $2000 / 01$ & $\begin{array}{r}\text { Prel. } \\
2001 / 02\end{array}$ \\
\hline \multicolumn{6}{|l|}{ Cotton manufactures } \\
\hline Cotton yarn & 1,532 & 1,540 & 1,670 & 1,721 & 1,799 \\
\hline Cotton cloth (in millions of square meters) & 340 & 385 & 437 & 490 & 599 \\
\hline \multicolumn{6}{|l|}{ Food and tobacco } \\
\hline White sugar & 3,555 & 3,542 & 2,429 & 2,956 & 3,247 \\
\hline Beverages (in thousands of bottles) & 1,798 & 2,219 & 2,332 & 2,542 & 2,492 \\
\hline Vegetable products & 719 & 773 & 698 & 835 & 774 \\
\hline Cigarettes (in billions) & 48 & 52 & 47 & 58 & 55 \\
\hline \multicolumn{6}{|l|}{ Chemicals } \\
\hline Urea & 3,284 & 3,522 & 3,785 & 4,005 & 4,217 \\
\hline Superphosphate & 0 & 22 & 146 & 160 & 161 \\
\hline Soda ash & 240 & 239 & 246 & 218 & 215 \\
\hline Caustic soda & 116 & 120 & 141 & 145 & 151 \\
\hline Sulphuric acid & 28 & 27 & 58 & 57 & 59 \\
\hline Ammonium nitrate & 316 & 339 & 387 & 374 & 329 \\
\hline Nitrophosphate & 293 & 285 & 261 & 282 & 306 \\
\hline Diammonium phosphate & 0 & 0 & 129 & 320 & 671 \\
\hline Cement (in millions of metric tons) & 9.4 & 9.6 & 9.3 & 9.7 & 10.0 \\
\hline Pig iron & 1,016 & 989 & 1,107 & 1,071 & 1,043 \\
\hline Billets & 350 & 276 & 344 & 415 & 412 \\
\hline Paperboard & 178 & 187 & 206 & 285 & 292 \\
\hline Chipboard & 166 & 173 & 228 & 246 & 256 \\
\hline Tractors (in thousands) & 14.1 & 26.9 & 35.0 & 32.4 & 24.3 \\
\hline Bicycles (in thousands) & 452 & 504 & 534 & 570 & 546 \\
\hline Motor tires (in thousands) & 767 & 845 & 856 & 884 & 911 \\
\hline
\end{tabular}

Sources: Federal Burean of Statistics

I/ July 2001-May 2002. 
Table 8. Pakistan: Consumer and Wholesale Price Indices, 1997/98-2001/02

\begin{tabular}{|c|c|c|c|c|c|c|}
\hline \multicolumn{7}{|c|}{$(1990 / 91=100)$} \\
\hline & \multicolumn{2}{|c|}{ Index (12-month average) } & \multicolumn{2}{|c|}{$\begin{array}{c}\text { 12-month percent } \\
\text { change } 1 /\end{array}$} & \multicolumn{2}{|c|}{$\begin{array}{c}\text { Year-on-year percent } \\
\text { change } 2 /\end{array}$} \\
\hline & CPI & WPI & CPI & WPI & CPI & WPI \\
\hline & \multicolumn{6}{|c|}{ (Fiscal year data) } \\
\hline $1997 / 98$ & 204.0 & 213.1 & 7.8 & 6.6 & 6.5 & 5.3 \\
\hline $1998 / 99$ & 215.7 & 226.6 & 5.7 & 6.3 & 3.7 & 4.6 \\
\hline $1999 / 2000$ & 223.4 & 230.6 & 3.6 & 1.8 & 5.1 & 3.4 \\
\hline $2000 / 01$ & 233.2 & 245.0 & 4.4 & 6.2 & 2.5 & 4.6 \\
\hline \multirow[t]{2}{*}{$2001 / 02$} & 239.7 & 250.2 & 2.7 & 3.7 & 3.2 & 2.4 \\
\hline & \multicolumn{6}{|c|}{ (Monthly data) } \\
\hline 2000:1 & 223.2 & 226.7 & 3.9 & 3,2 & 3.4 & -0.4 \\
\hline $2000: 2$ & 223.2 & 229.1 & 3.7 & 2.6 & 3.0 & 0.0 \\
\hline $2000: 3$ & 225.1 & 233.9 & 3.6 & 2.2 & 3.6 & 1.9 \\
\hline $2000: 4$ & 226.4 & 234.8 & 3.5 & 2.0 & 3.9 & 2.8 \\
\hline $2000: 5$ & 226.2 & 234.4 & 3.5 & 1.9 & 3.8 & 2.4 \\
\hline 2000:6 & 228.5 & 236.7 & 3.6 & 1.8 & 5.1 & 3.4 \\
\hline $2000: 7$ & 229.8 & 236.6 & 3.7 & 1.8 & 5.0 & 3.3 \\
\hline $2000: 8$ & 229.7 & 238.3 & 3.8 & 1.9 & 4.4 & 3.8 \\
\hline 2000:9 & 231.9 & 242.0 & 4.0 & 2.1 & 5.1 & 4.9 \\
\hline $2000: 10$ & 233.0 & 244.2 & 4.0 & 2.4 & 4.6 & 6.2 \\
\hline $2000 ; 11$ & 235.1 & 247.1 & 4.2 & 3.1 & 5.4 & 9.0 \\
\hline $2000: 12$ & 234.0 & 249.9 & 4.4 & 4.0 & 5.1 & 10.6 \\
\hline 2001:1 & 233.6 & 247.8 & 4.5 & 4.8 & 4.7 & 9.3 \\
\hline 2001:2 & 233.4 & 246.8 & 4.6 & 5.4 & 4.6 & 7.8 \\
\hline $2001: 3$ & 234.5 & 246.5 & 4.6 & 5.7 & 4.2 & 5.4 \\
\hline $2001: 4$ & 235.3 & 248.1 & 4.6 & 6.0 & 3.9 & 5.7 \\
\hline $2001: 5$ & 234.3 & 244.7 & 4.6 & 6.1 & 3.6 & 4.4 \\
\hline $2001: 6$ & 234.3 & 247.5 & 4.4 & 6.2 & 2.5 & 4.6 \\
\hline 2001:7 & 235.5 & 251.9 & 4.2 & 6.5 & 2.5 & 6.5 \\
\hline $2001: 8$ & 237.5 & 252.7 & 4.1 & 6.7 & 3.4 & 6.0 \\
\hline 2001:9 & 238.6 & 253.2 & 3.9 & 6.6 & 2.9 & 4.6 \\
\hline 2001:10 & 239.2 & 250,3 & 3.8 & 6.3 & 2.7 & 2.5 \\
\hline 2001:11 & 240.0 & 247.9 & 3.5 & 5.6 & 2.1 & 0.3 \\
\hline 2001:12 & 238.4 & 246.3 & 3.2 & 4.6 & 1.9 & -1.5 \\
\hline 2002:1 & 239.0 & 246.7 & 3.0 & 3.7 & 2.3 & -0.5 \\
\hline 2002:2 & 240.2 & 247.1 & 2.9 & 3.1 & 2.9 & 0.1 \\
\hline 2002:3 & 242.0 & 250.3 & 2.8 & 2.8 & 3.2 & 1.6 \\
\hline 2002:4 & 242.6 & 251.2 & 2.8 & 2.4 & 3.1 & 1.2 \\
\hline $2002: 5$ & 241.1 & 250.9 & 2.7 & 2.3 & 2.9 & 2.5 \\
\hline $2002 ; 6$ & 241,7 & 253.6 & 2.7 & 2.1 & 3.2 & 2.4 \\
\hline
\end{tabular}

Source: Federal Burean of Statistics.

1/ For fiscal year data, refers to the change in the 12-month average of the indices during the year. For monthly data, refers to the percentage change in the current month's 12-month average of the indices over that of the orresponding month of the preceding year.

2/ For fiscal year data, refers to the change in the indices at the end of the year. For monthly data, refers to the percentage change in the indices in any given month compared to the corresponding month of the preceding year. 
Table 9. Pakistan: Selected Commodity Prices, 1997/98-2001/02

(In Pakistani rupees per 100 kilograms)

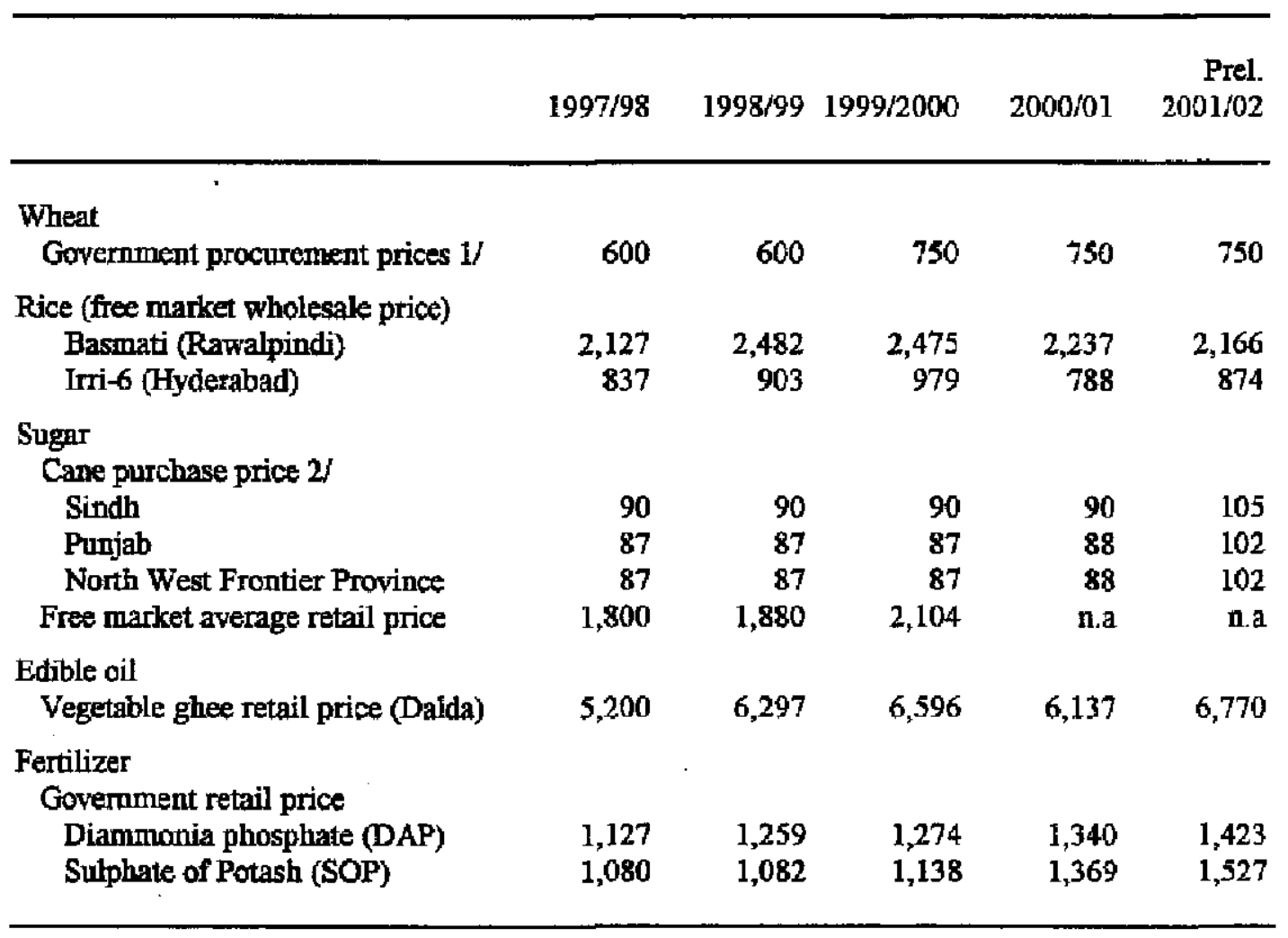

Sources: Ministry of Finance and Economic Affairs; and Ministry of Food, Agriculture, and Cooperatives.

1/ Usually announced in September/October.

2/Minimum procurement prices. 
Table 10. Pakistan: Increases in Procurement Prices of Selected Agricultural Commodities, 1997/98-2001/02

(Annual percentage changes)

\begin{tabular}{|c|c|c|c|c|c|}
\hline & $1997 / 98$ & $1998 / 99$ & $1999 / 2000$ & $2000 / 01$ & $2001 / 02$ \\
\hline Wheat & 0.0 & 0.0 & 25.0 & 0.0 & 0.0 \\
\hline $\begin{array}{l}\text { Rice (Paddy) } \\
\text { Basmati (385) } \\
\text { Irri-6 (fair/average quality) } \\
\text { Irri-6 (superior) }\end{array}$ & $\begin{array}{l}21.6 \\
18.6\end{array}$ & $\begin{array}{r}6.5 \\
14.4\end{array}$ & $\begin{array}{l}6.1 \\
5.7\end{array}$ & $\begin{array}{l}10.0 \\
10.8\end{array}$ & $\begin{array}{l}0.0 \\
0.0\end{array}$ \\
\hline $\begin{array}{l}\text { Seed Cotton (floor price) } \\
\text { Desi } \\
\text { B-557, 149-F, etc. } \\
\text { Sarmast, MS-39, etc. }\end{array}$ & $\begin{array}{r}2.3 \\
15.0 \\
14.8\end{array}$ & $\begin{array}{l}\text { n.a. } \\
\text { n.a. } \\
\text { n.a. }\end{array}$ & $\begin{array}{l}\text { n.a. } \\
\text { n.a. } \\
\text { n.a. }\end{array}$ & $\begin{array}{r}\text { n.a. } \\
-12.1 \\
\text { n.a. }\end{array}$ & $\begin{array}{c}\text { n.a. } \\
7.6 \\
\text { n.a. }\end{array}$ \\
\hline $\begin{array}{l}\text { Sugarcane } \\
\text { Sindh } \\
\text { Punjab } \\
\text { North West Frontier Province }\end{array}$ & $\begin{array}{l}46.9 \\
45.8 \\
45.8\end{array}$ & $\begin{array}{l}0.0 \\
0.0 \\
0.0\end{array}$ & $\begin{array}{l}0.0 \\
0.0 \\
0.0\end{array}$ & $\begin{array}{l}0.0 \\
0.0 \\
0.0\end{array}$ & $\begin{array}{l}19.4 \\
20.0 \\
20.0\end{array}$ \\
\hline
\end{tabular}

Source: Ministry of Food, Agriculture, and Cooperatives. 
Table 11. Pakistan: Domestic Retail Prices of Selected Petroleum Products, 1997/98-2001/02 (In Pakistani rupees per liter) $1 /$

\begin{tabular}{lrrrrr}
\hline & $1997 / 98$ & $1998 / 99$ & $1999 / 2000$ & $2000 / 01$ & $2001 / 02$ \\
\hline Regular petrol 2/ & 17.60 & 22.24 & 25.98 & 25.75 & 31.48 \\
High-octane petrol & 20.47 & 25.89 & 30.58 & 33.57 & 35.79 \\
Kerosene & 9.44 & 9.56 & 10.91 & 14.32 & 15.24 \\
High speed diesel & 9.66 & 9.78 & 11.49 & 15.58 & 16.51 \\
Light diesel & 7.79 & 7.87 & 9.28 & 13.57 & 14.3 \\
Fuel oil 3/4/ & 6,251 & 5,567 & 7,170 & $\ldots$ & $\ldots$ \\
\hline
\end{tabular}

Source: Ministry of Petroleum and Natural Resources.

1/ Anmual averages.

2/ MS 87-RON.

3/ Pakistan rupees per metric ton.

4/ Fuel oil prices were deregulated with effect from July 1, 2000. 
Table 12. Pakistan: Natural Gas Prices, 1997/98-2001/02

(In Pakistani nupees per thousand cabic feet)

\begin{tabular}{lrrrrr}
\hline & $\begin{array}{r}\text { Jan. 1 } \\
1997\end{array}$ & $\begin{array}{r}\text { Aug. 16 } \\
1999\end{array}$ & $\begin{array}{r}\text { Jul. 1 } \\
2000\end{array}$ & $\begin{array}{r}\text { Mar. 17 } \\
2001\end{array}$ & $\begin{array}{r}\text { Mar. 1 } \\
2002\end{array}$ \\
& & & & & \\
\hline Fertilizer industry & 34.01 & 34.01 & 34.01 & 34.01 & 36.77 \\
Other industries & 102.46 & 120.00 & 138.00 & 157.87 & 166.18 \\
Household & & & & & \\
$\quad$ Up to 3.55 mcf/month & 49.09 & 55.23 & 63.51 & 63.51 & 66.86 \\
From 3.55 to 7.1 mcf/month & 50.75 & 65.58 & 75.53 & 88.72 & 100.73 \\
From 7.1 to 10.65 mcf/month & 69.30 & 89.66 & 103.11 & 131.98 & 161.16 \\
From 10.65 to 14.20 mcf/month & 83.16 & 107.58 & 123.72 & 172.46 & 201.45 \\
Above 14.20 mcf/month & $\ldots$ & $\ldots$ & $\ldots$ & $\ldots$. & 217.85 \\
Commercial & 115.28 & 135.02 & 155.27 & 177.63 & 186.98 \\
\hline
\end{tabular}

Sources: Ministry of Petroleum and Natural Resources. 
Table 13. Pakistan: Summary of Consolidated Federal and Provincial Budgetary Operations, 1997/98-2001/02 1/

\begin{tabular}{|c|c|c|c|c|c|}
\hline & $1997 / 98$ & $1998 / 99$ & $1999 / 2000$ & $2000 / 01$ & $\begin{array}{r}\text { Prel. } \\
2001 / 02\end{array}$ \\
\hline & \multicolumn{5}{|c|}{ (In billions of Pakistani rupees) } \\
\hline Total revenue & 423.0 & 488.6 & 546.0 & 593.4 & 700.1 \\
\hline $\operatorname{Tax}$ & 349.0 & 388.8 & 405.6 & 441.5 & 471.0 \\
\hline Of which: CBR revenne $2 /$ & 288.7 & 311.4 & 346.6 & 392.1 & 403.9 \\
\hline Of which: surcharges & 46.3 & 61.9 & 38.9 & 30.3 & 47.3 \\
\hline Nontax & 74.0 & 86.1 & 107.0 & 111.3 & 145.9 \\
\hline Grants & 0.0 & 13.7 & 33.4 & 40.5 & 83.] \\
\hline Total expenditure & 628.4 & 633.8 & 709.1 & 717.8 & 871.3 \\
\hline Current $3 /$ & 522.9 & 546.1 & 626.4 & 645.7 & 713.3 \\
\hline Of which: interest $4 /$ & 196.3 & 213.3 & 245.1 & 234.5 & 245.3 \\
\hline Of which: defense & 136.2 & 143.5 & 150.4 & 130.8 & 149.0 \\
\hline Development and net lending 5/ & 105.5 & 87.7 & 82.7 & 72.2 & 158.0 \\
\hline Statistical discrepancy & -0.4 & 17.4 & 9.8 & 14.7 & -13.2 \\
\hline Budget balance & -205.0 & $-162,6$ & -172.9 & -139.1 & -158.0 \\
\hline Financing & 205.0 & 162.6 & 172.9 & 139.1 & 158.0 \\
\hline Extemal & 38.8 & 133.3 & 36.3 & 80,2 & 51.7 \\
\hline Domestic & 166.2 & 29.3 & 136.6 & 58.9 & 97.9 \\
\hline Bank & 48.0 & -75.0 & 40.0 & -33.1 & 13.0 \\
\hline Nonbank & 118.1 & 104.3 & 96.6 & 92.0 & 85.0 \\
\hline \multirow[t]{2}{*}{ Privatization proceeds } & 0.0 & 0.0 & 0.0 & 0.0 & 8.4 \\
\hline & \multicolumn{5}{|c|}{ (In percent of GDP) } \\
\hline Total revenue & 15.8 & 16,6 & 17.3 & 17.4 & 18.8 \\
\hline $\operatorname{Tax}$ & 13,0 & 13.2 & 12.9 & 12.9 & 12.6 \\
\hline Of which: CBR revenue 2 & 10.8 & 10.6 & 11.0 & 11.5 & 10.8 \\
\hline Of which: surcharges & 1.7 & 2.1 & 1.2 & 0.9 & 1.3 \\
\hline Nontax & 2.8 & 29 & 3.4 & 3.3 & 3.9 \\
\hline Total expenditure & 23.5 & 21,6 & 22.5 & 21.0 & 23.4 \\
\hline Current 3/ & 19.5 & 18.6 & 19.9 & 18.9 & 19.1 \\
\hline Of which : interest $4 /$ & 7.3 & 7.3 & 7.8 & 6.9 & 6.6 \\
\hline Of which: defense & 5.1 & 4.9 & 4.8 & 3.8 & 4.0 \\
\hline Development and net lending 5/ & 3,9 & 3.0 & 2.6 & 2.1 & 4.2 \\
\hline Statistical discrepancy & 0.0 & 0.6 & 0.3 & 0.4 & -0.4 \\
\hline Budget deficit & -7.7 & -5.5 & -5.5 & -4.1 & -4.2 \\
\hline \multicolumn{6}{|l|}{ Memorandum items: } \\
\hline Current balance & -3.7 & -3.0 & -4.2 & -3.7 & -2.3 \\
\hline Primary balance & -0.3 & 2.3 & 2.6 & 3.2 & 2.0 \\
\hline Gross government debt $6 /$ & 93.7 & 93.0 & 93.3 & 109.2 & 98.3 \\
\hline
\end{tabular}

Source: Ministry of Finance and Economic Affairs.

1/ Differences with staff report tables are on account of rounding errors unless otherwise specified. $2 /$ Includes income and profits taxes, wealth and capital taxes, federal excise duty, sales tax, and customs duties.

$3 /$ Includes settlement of tax refunds on behalf of the CBR for PRs 20 billion in 2001/02.

4/ Accrued payments. Excludes interest expenciture by the military which is included in the defense allocation.

5/ Includes certain current outlays under the public sector development program. Also includes recapitalization of KESC for PRs 32 billion in 2001/02.

$6 /$ Foreign currency debt is valued at the end-of-period exchange rate. 
Table 14. Pakistan: Consolidated Federal and Provincial Revenue, 1997/98-2001/02

\begin{tabular}{|c|c|c|c|c|c|}
\hline & $1997 / 98$ & $1998 / 99$ & $1999 / 2000$ & $2000 / 01$ & $\begin{array}{r}\text { Prel. } \\
2001 / 02\end{array}$ \\
\hline & \multicolumn{5}{|c|}{ (In millions of Pakistani rupees) } \\
\hline Total revenue & 423,007 & 488,604 & 546,012 & 593,380 & 700,128 \\
\hline Tax revenue & 348,961 & 388,788 & 405,609 & 441,525 & 471,045 \\
\hline Taxes on income and profit & 91,499 & 94,649 & 108,011 & 124,566 & 142,589 \\
\hline $\begin{array}{l}\text { Taxes on property } \\
\text { Federal } \\
\text { Provincial }\end{array}$ & $\begin{array}{r}11,917 \\
7,723 \\
4,194\end{array}$ & $\begin{array}{r}12,973 \\
8,812 \\
4,161\end{array}$ & $\begin{array}{l}8,473 \\
4,597 \\
3,876\end{array}$ & $\begin{array}{r}5,912 \\
0 \\
5,912\end{array}$ & $\begin{array}{r}3,446 \\
0 \\
3,446\end{array}$ \\
\hline Taxes on goods and services & 155,098 & 192,443 & 212,573 & 234,076 & 261,860 \\
\hline $\begin{array}{l}\text { Excise duty } \\
\text { Federal } \\
\text { Provincial }\end{array}$ & $\begin{array}{r}59,706 \\
58,795 \\
911\end{array}$ & $\begin{array}{r}61,836 \\
60,572 \\
1,264\end{array}$ & $\begin{array}{r}56,964 \\
55,630 \\
1,334\end{array}$ & $\begin{array}{r}50,313 \\
49,018 \\
1,295\end{array}$ & $\begin{array}{r}48,286 \\
46,920 \\
1,366\end{array}$ \\
\hline Sales tax & 49,046 & 68,680 & 116,697 & 153,474 & 166,316 \\
\hline $\begin{array}{l}\text { Surcharges } \\
\text { Gas } \\
\text { Petroleum }\end{array}$ & $\begin{array}{r}46,346 \\
9,800 \\
36,546\end{array}$ & $\begin{array}{r}61,927 \\
9,855 \\
52,072\end{array}$ & $\begin{array}{l}38,912 \\
13,509 \\
25,403\end{array}$ & $\begin{array}{l}30,289 \\
12,348 \\
17,942\end{array}$ & $\begin{array}{l}47,258 \\
17,694 \\
29,564\end{array}$ \\
\hline Taxes on international trade & 81,644 & 78,654 & 61,638 & 65,013 & 48,072 \\
\hline $\begin{array}{l}\text { Other taxes } \\
\text { Stamp duties } \\
\text { Motor vehicles tax } \\
\text { Foreign trąvel tax } \\
\text { Other }\end{array}$ & $\begin{array}{r}8,803 \\
4,814 \\
2,113 \\
1,468 \\
408\end{array}$ & $\begin{array}{r}10,069 \\
5,267 \\
2,362 \\
1,466 \\
974\end{array}$ & $\begin{array}{r}14,914 \\
6,398 \\
2,803 \\
1,350 \\
4,363\end{array}$ & $\begin{array}{r}11,958 \\
5,098 \\
3,100 \\
184 \\
3,576\end{array}$ & $\begin{array}{r}15,078 \\
5,729 \\
3,203 \\
1,097 \\
5,049\end{array}$ \\
\hline $\begin{array}{l}\text { Nontax revenue } \\
\text { Interest } \\
\text { Dividend } \\
\text { SBP profits } \\
\text { Other civil administration } \\
\text { Miscellaneous }\end{array}$ & $\begin{array}{r}74,046 \\
18,090 \\
7,766 \\
18,000 \\
7,767 \\
22,423\end{array}$ & $\begin{array}{r}86,113 \\
16,448 \\
9,553 \\
8,000 \\
6,226 \\
45,886\end{array}$ & $\begin{array}{r}106,960 \\
25,883 \\
14,145 \\
30,000 \\
3,186 \\
33,746\end{array}$ & $\begin{array}{r}111,313 \\
23,365 \\
16,334 \\
20,000 \\
3,387 \\
48,228\end{array}$ & $\begin{array}{r}145,936 \\
25,072 \\
26,607 \\
26,000 \\
22,186 \\
46,071\end{array}$ \\
\hline \multirow[t]{2}{*}{ Grants } & 0 & 13,703 & 33,443 & 40,542 & 83,147 \\
\hline & \multicolumn{5}{|c|}{ (In percent of GDP) } \\
\hline Tax revenue & 13.0 & 13,2 & 12.9 & 12.9 & 12.6 \\
\hline Taxes on income and profit & 3.4 & 3.2 & 3.4 & 3.6 & 3.8 \\
\hline Taxes on property & 0.4 & 0.4 & 0.3 & 0.2 & 0.1 \\
\hline $\begin{array}{l}\text { Taxes on goods and services } \\
\text { Excise duty } \\
\text { Sales tax } \\
\text { Surcharges }\end{array}$ & $\begin{array}{l}5.8 \\
2.2 \\
1.8 \\
1.7\end{array}$ & $\begin{array}{l}6.5 \\
2.1 \\
2.3 \\
2.1\end{array}$ & $\begin{array}{l}6.8 \\
1.8 \\
3.7 \\
1.2\end{array}$ & $\begin{array}{l}6.9 \\
1.5 \\
4.5 \\
0.9\end{array}$ & $\begin{array}{l}7.0 \\
1.3 \\
4.5 \\
1.3\end{array}$ \\
\hline Taxes on international trade & 3.0 & 2.7 & 2.0 & 1.9 & 1.3 \\
\hline Other taxes & 0.3 & 0.3 & 0.5 & 0.4 & 0.4 \\
\hline Nontax revenue & 2.8 & 2,9 & 3.4 & 3.3 & 3.9 \\
\hline
\end{tabular}

Source: Ministry of Finance and Economic Affairs. 
Table 15. Pakistan: Consolidated Federal and Provincial Expenditure, 1997/98-2001/02

\begin{tabular}{|c|c|c|c|c|c|}
\hline 1996 & $1997 / 98$ & $1998 / 99$ & $1999 / 2000$ & $2000 / 01$ & $\begin{array}{r}\text { Prel. } \\
2001 / 02\end{array}$ \\
\hline & \multicolumn{5}{|c|}{ (In millions of Pakistani nupees) } \\
\hline Total expenditure & 628,398 & 633,812 & 709,076 & 717,849 & 871,282 \\
\hline Current expenditure & 522,910 & 546,130 & 626,379 & 645,685 & 713,262 \\
\hline $\begin{array}{l}\text { Federal } \\
\text { Interest payments } 1 /\end{array}$ & $\begin{array}{l}400,122 \\
196,251\end{array}$ & $\begin{array}{l}423,737 \\
213,259\end{array}$ & $\begin{array}{l}477,874 \\
245,078\end{array}$ & $\begin{array}{l}478,988 \\
234,470\end{array}$ & $\begin{array}{l}537,657 \\
245,263\end{array}$ \\
\hline Domestic & 167,513 & 175,273 & 198,417 & 183,450 & 184,632 \\
\hline Foreign & 28,738 & 37,986 & 46,661 & 51,020 & 60,631 \\
\hline Defenise $2 /$ & 136,164 & 143,471 & 150,390 & 130,819 & 149,029 \\
\hline General administration and services & 47,539 & 46,907 & 47,525 & 75,424 & 83,482 \\
\hline Grants to nongovernment 3 / & 5,294 & 4,240 & 12,615 & 18,102 & 42,843 \\
\hline Subsidies & 6,267 & 9,533 & 14,748 & 19,850 & 16,742 \\
\hline Other & 8,607 & 6,327 & 7,518 & 323 & 298 \\
\hline Provincial & 122,788 & 122,393 & 148,505 & 166,697 & 175,605 \\
\hline Development and net lending & 105,488 & 87,682 & 82,697 & 72,164 & 158,020 \\
\hline PSDP 4 & 105,210 & 108,994 & 95,589 & 89,804 & 126,250 \\
\hline \multirow[t]{2}{*}{ Net lending } & 278 & $-21,312$ & $-12,892$ & $-17,640$ & 31,770 \\
\hline & \multicolumn{5}{|c|}{ (In percent of GDP) } \\
\hline Total expenditure & 23.5 & 21.6 & 22.5 & 21.0 & 23.4 \\
\hline Current expenditure & 19.5 & 18.6 & 19.9 & 18.9 & 19.1 \\
\hline $\begin{array}{l}\text { Federal } \\
\text { Of which: }\end{array}$ & 14.9 & 14.4 & 15.2 & 14.0 & 14.4 \\
\hline Interest payments $1 /$ & 7.3 & 7.3 & 7.8 & 6.9 & 6.6 \\
\hline Domestic & 6.3 & 6.0 & 6.3 & 5.4 & 5.0 \\
\hline Foreign & 1.1 & 1.3 & 1.5 & 1.5 & 1.6 \\
\hline Defense $2 /$ & 5.1 & 4.9 & 4.8 & 3.8 & 4.0 \\
\hline Provincial & 4.6 & 4.2 & 4.7 & 4.9 & 4.7 \\
\hline Development and net lending 4/ & 3.9 & 3.0 & 2.6 & 2.1 & 4.2 \\
\hline
\end{tabular}

Source: Ministry of Finance and Economic Affairs.

1/ Accrued payments. Excludes interest expenditure by the military which is included in the defense allocation. $2 /$ Inchudes interest and principal payments on military debt; excludes military imports financed by external grants and disbursements.

3/ Lncludes settlement of tax refunds on behalf of the CBR for PRs 20 billion in 2001/02.

4/ Includes certain current outlays under the public sector development program. Also inciudes recapitalization of KESC for PRs 32 billion in 2001/02. 
Table 16. Pakistan: Federal Government Fiscal Operations, 1997/98-2001/02

(In millions of Pakistani rupees)

\begin{tabular}{|c|c|c|c|c|c|}
\hline & $1997 / 98$ & $1998 / 99$ & $1999 / 2000$ & $2000 / 01$ & $\begin{array}{r}\text { Prel. } \\
2001 / 02\end{array}$ \\
\hline Total revenue (inchuding grants) & 310,978 & 368,432 & 396,133 & 420,799 & 518,115 \\
\hline $\begin{array}{l}\text { Tax revenue (net) } \\
\text { Transfers to provincial tax pool }\end{array}$ & $\begin{array}{l}220,975 \\
114,078\end{array}$ & $\begin{array}{l}257,721 \\
115,573\end{array}$ & $\begin{array}{l}243,604 \\
143,231\end{array}$ & $\begin{array}{l}259,414 \\
163,131\end{array}$ & $\begin{array}{l}280,786 \\
171,466\end{array}$ \\
\hline Tax revenue (gross) & 335,053 & 373,294 & 386,835 & 422,545 & 452,252 \\
\hline Income and profit taxes & 91,499 & 94,649 & $108,01]$ & 124,566 & 142,589 \\
\hline Wealth and capital taxes & 7,723 & 8,812 & 4,597 & 0 & 0 \\
\hline Fexeral excise duty & 58,795 & 60,572 & 55,630 & 49,018 & 46,920 \\
\hline Sales tax & 49,046 & 68,680 & 116,697 & 153,474 & 166,316 \\
\hline Customs duties & 81,644 & 78,654 & 61,638 & 65,013 & 48,072 \\
\hline Surcharges & 46,346 & 61,927 & 38,912 & 30,290 & 47,258 \\
\hline Gas & 9,800 & 9,855 & 13,509 & 12,348 & 37,694 \\
\hline Petroleum & 36,546 & 52,072 & 25,403 & 17,942 & 29,564 \\
\hline Foreign travel tax & 0 & 0 & 1,350 & 184 & 1,097 \\
\hline Nontex reverue & 90,003 & 97,008 & 119,086 & 120,843 & 154,182 \\
\hline Interest receipts (provinces) & 26,010 & 25,469 & 28,270 & 29,368 & 29,528 \\
\hline Interest receipts (other) & 16,556 & 16,205 & 25,070 & 21,885 & 23,821 \\
\hline Dividend & 7,766 & 9,553 & 14,145 & 16,334 & 26,607 \\
\hline SBP profit & 18,000 & 8,000 & 30,000 & 20,000 & 26,000 \\
\hline Other civil administration & 7,767 & 6,226 & 3,186 & 3,387 & 22,186 \\
\hline Other federal misceltaneous & 13,706 & 31,221 & 18,415 & 29,870 & 26,040 \\
\hline Capital revenue & 198 & 334 & 0 & 0 & 0 \\
\hline Grants & 0 & 13,703 & 33,443 & 40,542 & 83,147 \\
\hline Expendifure and net lending & 500,344 & 511,224 & 566,777 & 554,883 & 688,027 \\
\hline Current expenditures & 411,003 & 435,821 & 498,876 & 496,508 & 554,175 \\
\hline Interest payments if & 196,251 & 213,259 & 245,078 & 234,470 & 245,263 \\
\hline Domestic 1 & 167,513 & 175,273 & 198,417 & 183,450 & 184,632 \\
\hline Foreign & 28,738 & 37,986 & 46,661 & 51,020 & 60,631 \\
\hline Defense 2/ & 136,164 & 143,471 & 150,390 & 130,819 & 149,029 \\
\hline General administration & 47,539 & 46,907 & 47,525 & 75,424 & 83,482 \\
\hline Grants & 16,175 & 16,324 & 33,617 & 35,622 & 59,361 \\
\hline Provinces & 10,881 & 12,084 & 21,002 & 17,520 & 16,518 \\
\hline Other & 5,294 & 4,240 & 12,615 & 18,102 & 42,843 \\
\hline Subsidies & 6,267 & 9,533 & 14,748 & 19,850 & 16,742 \\
\hline Other & 8,607 & 6,327 & 7,518 & 323 & 298 \\
\hline Development expenditure and net lending & 89,341 & 75,403 & 67,901 & 58,375 & 133,852 \\
\hline Public Sector Development Program $3 /$ & 81,000 & 85,419 & 59,336 & 66,908 & 98,377 \\
\hline Net lending & 8,341 & $-10,016$ & 8,565 & $-8,533$ & 35,475 \\
\hline Provinces & 8,063 & 11,296 & 21,457 & 9,107 & 3,705 \\
\hline Other & 278 & $-21,312$ & $-12,892$ & $-17,640$ & 31,770 \\
\hline Statistical discrepancy & 14,796 & 27,723 & 7,011 & 29,794 & 13,809 \\
\hline Overall balance & $-204,162$ & $-170,515$ & $-177,655$ & $-163,878$ & $-183,721$ \\
\hline Financing & 204,162 & 170,515 & 177,655 & 163,878 & 183,721 \\
\hline External & 38,839 & 133,299 & 36,328 & 80,212 & 51,678 \\
\hline Domestic & 165,323 & 37,216 & 141,327 & 83,666 & 123,691 \\
\hline Bank & 47,194 & $-67,052$ & 44,713 & $-8,349$ & 38,724 \\
\hline Nonbank & 118,129 & 104,268 & 96,614 & $\$ 2,015$ & 84,967 \\
\hline Privatization proceeds & 0 & 0 & 0 & 0 & 8,352 \\
\hline
\end{tabular}

Source: Ministry of Finance and Economic Affairs.

1/ Accrued pryments. Excludes interest expenditure by the military which is included in the defense allocation.

$2 /$ Includes interest and principal payments on military debt; excludes military imports financed by external grants and disbursements.

3/ Includes certain current outlays under the public sector development progrem. 
Table 17. Pakistan: Provincial Government Fiscal Operations, 1997/98-2001/02

\begin{tabular}{|c|c|c|c|c|c|}
\hline & $1997 / 98$ & $1998 / 99$ & $1999 / 2000$ & $2000 / 01$ & $\begin{array}{r}\text { Prel. } \\
2001 / 02\end{array}$ \\
\hline & \multicolumn{5}{|c|}{ (In millions of Pakistani rupees) } \\
\hline Total revenue & 156,983 & 169,021 & 220,608 & 228,577 & 231,764 \\
\hline Provincial share in federal revenue & 114,078 & 115,573 & 143,231 & 163,131 & 171,466 \\
\hline $\begin{array}{l}\text { Provincial taxes } \\
\text { Property taxes } \\
\text { Excise duties } \\
\text { Stamp duties } \\
\text { Motor vehicles tax } \\
\text { Other }\end{array}$ & $\begin{array}{r}13,908 \\
4,194 \\
911 \\
4,814 \\
2,113 \\
1,876\end{array}$ & $\begin{array}{r}15,494 \\
4,161 \\
1,264 \\
5,267 \\
2,362 \\
2,440\end{array}$ & $\begin{array}{r}18,774 \\
3,876 \\
1,334 \\
6,398 \\
2,803 \\
4,363\end{array}$ & $\begin{array}{r}18,981 \\
5,912 \\
1,295 \\
5,098 \\
3,100 \\
3,576\end{array}$ & $\begin{array}{r}18,793 \\
3,446 \\
1,366 \\
5,729 \\
3,203 \\
5,049\end{array}$ \\
\hline $\begin{array}{l}\text { Provincial nontax } \\
\text { Interest } \\
\text { Profits from hydro electricity } \\
\text { Other }\end{array}$ & $\begin{array}{r}10,053 \\
1,534 \\
5,442 \\
3,077\end{array}$ & $\begin{array}{r}14,574 \\
243 \\
6,000 \\
8,331\end{array}$ & $\begin{array}{r}16,144 \\
813 \\
6,000 \\
9,331\end{array}$ & $\begin{array}{r}19,838 \\
1,480 \\
5,244 \\
13,114\end{array}$ & $\begin{array}{r}21,282 \\
1,251 \\
6,000 \\
14,031\end{array}$ \\
\hline $\begin{array}{l}\text { Federal loans and transfers } \\
\text { Loans (net) } \\
\text { Grants }\end{array}$ & $\begin{array}{r}18,944 \\
8,063 \\
10,881\end{array}$ & $\begin{array}{l}23,380 \\
11,296 \\
12,084\end{array}$ & $\begin{array}{l}42,459 \\
21,457 \\
21,002\end{array}$ & $\begin{array}{r}26,627 \\
9,107 \\
17,520\end{array}$ & $\begin{array}{r}20,223 \\
3,705 \\
16,518\end{array}$ \\
\hline Total expenditure & 173,008 & 171,437 & 213,028 & 218,962 & 233,006 \\
\hline $\begin{array}{l}\text { Current expenditure } \\
\text { Interest to federal government } \\
\text { Other } \\
\text { Development expenditure }\end{array}$ & $\begin{array}{r}148,798 \\
26,010 \\
122,788 \\
24,210\end{array}$ & $\begin{array}{r}147,862 \\
25,469 \\
122,393 \\
23,575\end{array}$ & $\begin{array}{r}176,775 \\
28,270 \\
148,505 \\
36,253\end{array}$ & $\begin{array}{r}196,066 \\
29,369 \\
166,697 \\
22,896\end{array}$ & $\begin{array}{r}205,133 \\
29,528 \\
175,605 \\
27,873\end{array}$ \\
\hline Statistical discrepancy & $-15,191$ & $-10,350$ & 2,830 & $-15,133$ & $-27,012$ \\
\hline Overall balance & -834 & 7,934 & 4,750 & 24,748 & 25,770 \\
\hline $\begin{array}{l}\text { Financing } \\
\text { External } \\
\text { Domestic } \\
\text { Bank } \\
\text { Wonbank } \\
\text { Privatization proceeds }\end{array}$ & $\begin{array}{r}834 \\
0 \\
834 \\
834 \\
0 \\
0\end{array}$ & $\begin{array}{r}-7,934 \\
0 \\
-7,934 \\
-7,934 \\
0 \\
0\end{array}$ & $\begin{array}{r}-4,750 \\
0 \\
-4,750 \\
-4,750 \\
0 \\
0\end{array}$ & $\begin{array}{r}-24,748 \\
0 \\
-24,748 \\
-24,748 \\
0 \\
0\end{array}$ & $\begin{array}{r}-25,770 \\
0 \\
-25,770 \\
-25,770 \\
0 \\
0\end{array}$ \\
\hline Privatization proceds & \multicolumn{5}{|c|}{ (In percent of GDP) } \\
\hline Total revenue & 5.9 & 5.8 & 7.0 & 6.7 & 6.2 \\
\hline Provincial share in fed. revenue & 4.3 & 3.9 & 4.6 & 4,8 & 4.6 \\
\hline $\begin{array}{l}\text { Provincial taxes } \\
\text { Provincial nottax } \\
\text { Federal loans and transfers }\end{array}$ & $\begin{array}{l}0.5 \\
0.4 \\
0.7\end{array}$ & $\begin{array}{l}0.5 \\
0.5 \\
0.8\end{array}$ & $\begin{array}{l}0.6 \\
0.5 \\
1.3\end{array}$ & $\begin{array}{l}0.6 \\
0.6 \\
0.8\end{array}$ & $\begin{array}{l}0.5 \\
0.6 \\
0.5\end{array}$ \\
\hline Total expenditure & 6.5 & 5.8 & 6.8 & 6.4 & 6.3 \\
\hline $\begin{array}{l}\text { Current expenditure } \\
\text { Development expenditure }\end{array}$ & $\begin{array}{l}5.6 \\
0.9\end{array}$ & $\begin{array}{l}5.0 \\
0.8\end{array}$ & $\begin{array}{l}5.6 \\
1.2\end{array}$ & $\begin{array}{l}5.7 \\
0.7\end{array}$ & $\begin{array}{l}5.5 \\
0.7\end{array}$ \\
\hline Overall balance & 0.0 & 0.3 & 0.2 & 0.7 & 0.7 \\
\hline
\end{tabular}

Source: Ministry of Finance and Economic Affairs. 
Table 18. Pakistan: Social and Poverty Related Expenditure, 1997/98-2001/02

\begin{tabular}{|c|c|c|c|c|c|}
\hline & $1997 / 98$ & \multicolumn{2}{|c|}{$1998 / 99 \quad 1999 / 2000$} & $2000 / 01$ & $\begin{array}{r}\text { Prel } \\
2001 / 02\end{array}$ \\
\hline & \multicolumn{5}{|c|}{ (In billions of Pabdistani rupees) } \\
\hline Total & 100.4 & 103.9 & 114.4 & 122.3 & 133.5 \\
\hline Current & 77.8 & 79.8 & 90.4 & 99.2 & 106.2 \\
\hline Development & 22.6 & 24.1 & 24.0 & 23.2 & 27.3 \\
\hline \multicolumn{6}{|l|}{ By functional area } \\
\hline Education & 49.1 & 49.4 & 54.0 & 56.5 & 66.3 \\
\hline Health & 14.7 & 15.5 & 17.3 & 17.5 & 19.2 \\
\hline Population planning & 2.0 & 2.6 & 3.4 & 1.6 & 1.3 \\
\hline Social security and social welfare & 1.9 & 2.0 & 2,1 & 1.6 & 3.7 \\
\hline Food subsidies & 7.3 & 7.1 & 9.9 & 9.4 & 5.5 \\
\hline Food support program & $\ldots$ & $\ldots$ & $\ldots$ & 1.1 & 2.0 \\
\hline Natural calamities and other disasters & 0.2 & 1.1 & 1.2 & 0.9 & 0.2 \\
\hline Rural development & 3.6 & 4.9 & 6.5 & 11.4 & 12.3 \\
\hline Roads, highways, and bridges & 5.2 & 6.0 & 5.1 & 8.3 & 6.3 \\
\hline Water supply and sanitation & 6.1 & 5.3 & 5.6 & 4.5 & 4.6 \\
\hline Irrigation & 9.7 & 9.1 & 8.3 & 8.2 & 10.1 \\
\hline \multirow[t]{2}{*}{ Land reclamation } & 0.5 & 0.8 & 0.9 & 1.4 & 1.8 \\
\hline & \multicolumn{5}{|c|}{ (In percent of GDP) } \\
\hline Total & 3.7 & 3.5 & 3.6 & 3.6 & 3.6 \\
\hline Current & 2.9 & 2.7 & 2.9 & 2.9 & 2.9 \\
\hline Development & 0,8 & 0.8 & 0.8 & 0.7 & 0.7 \\
\hline \multicolumn{6}{|l|}{ By functional area } \\
\hline Education & 1.8 & 1.7 & 1.7 & 1.7 & 1.8 \\
\hline Health & 0.6 & 0.5 & 0.6 & 0.5 & 0.5 \\
\hline Population planning & 0.1 & 0.1 & 0.1 & 0.0 & 0.0 \\
\hline Social security and social welfare & 0,1 & 0.1 & 0.1 & 0.0 & 0.1 \\
\hline Food subsidies & 0.3 & 0.2 & 0.3 & 0.3 & 0.1 \\
\hline Food support program & $\ldots$ & $\ldots$ & $\ldots$ & 0.0 & 0.1 \\
\hline Natural calamities and other disasters & 0.0 & 0.0 & 0.0 & 0.0 & 0.0 \\
\hline Rural development & 0.1 & 0.2 & 0,2 & 0.3 & 0.3 \\
\hline Roads, highways, and bridges & 0.2 & 0.2 & 0,2 & 0.2 & 0.2 \\
\hline Water supply and sanitation & 0.2 & 0.2 & 0.2 & 0.1 & 0.1 \\
\hline Irrigation & 0.4 & 0.3 & 0.3 & 0.2 & 0.3 \\
\hline Land reclamation & 0.0 & 0.0 & 0.0 & 0.0 & 0.0 \\
\hline \multicolumn{6}{|l|}{ Memorandum item: } \\
\hline \multicolumn{6}{|l|}{ Khushal Pakistan Program } \\
\hline In billions of Pakistani rupees & $\cdots$ & $\cdots$ & 3.5 & 3,0 & 15.0 \\
\hline In percent of GDP & $\ldots$ & $\ldots$ & 0.1 & 0.1 & 0.4 \\
\hline
\end{tabular}

Source: Ministry of Finance and Economic Affairs. 
Table 19. Pakistan: Financing of the Consolidated Budget, 1997/98-2001/02

(In millions of Pakistani rupees)

\begin{tabular}{|c|c|c|c|c|c|}
\hline & $1997 / 98$ & $1998 / 99$ & $1999 / 2000$ & $2000 / 01$ & $\begin{array}{r}\text { Prel } \\
2001 / 02\end{array}$ \\
\hline Total financing & 204,996 & 162,581 & 172,905 & 139,130 & 157,951 \\
\hline $\begin{array}{l}\text { External } \\
\text { Disbursements }\end{array}$ & $\begin{array}{r}38,839 \\
122,609\end{array}$ & $\begin{array}{l}133,299 \\
256,468\end{array}$ & $\begin{array}{r}36,328 \\
164,356\end{array}$ & $\begin{array}{r}80,212 \\
166,081\end{array}$ & $\begin{array}{r}51,678 \\
210,252\end{array}$ \\
\hline $\begin{array}{l}\text { Project aid } \\
\text { Commodity aid (nonfood) }\end{array}$ & $\begin{array}{r}48,706 \\
5,564\end{array}$ & $\begin{array}{l}46,943 \\
27,333\end{array}$ & $\begin{array}{r}43,387 \\
6,460\end{array}$ & $\begin{array}{l}44,200 \\
41,233\end{array}$ & $\begin{array}{l}37,020 \\
54,265\end{array}$ \\
\hline Food aid & 26,617 & 12,639 & 9,845 & 0 & 1,879 \\
\hline Other loans $1 /$ & 44,168 & 10,066 & 6,054 & 46,132 & 50,477 \\
\hline F-16 reimbursement & 0 & 16,445 & 0 & 0 & 4,912 \\
\hline Special dollar bonds & $\mathbf{0}$ & 54,337 & 0 & 0 & 0 \\
\hline Foreign exchange bearer certificates (net) & $-1,633$ & $-2,243$ & 0 & 0 & 0 \\
\hline U.S. dollar bearer certificates (net) & -70 & -6 & 0 & 0 & 0 \\
\hline Foreign currency bearer certificates (net) & -743 & $-1,194$ & 0 & 0 & 0 \\
\hline Debt rescheduling & 0 & $\mathbf{9 2 , 1 4 7}$ & 98,609 & 34,516 & 61,699 \\
\hline Repayments (due) & 83,770 & 123,169 & 128,028 & 85,869 & 158,574 \\
\hline Domestic & 166,157 & 29,282 & 136,577 & 58,918 & 97,921 \\
\hline Bank & 48,028 & $-74,986$ & 39,963 & $-33,097$ & 12,954 \\
\hline Federal & 47,194 & $-67,052$ & 44,713 & $-8,349$ & 38,724 \\
\hline Provincial & 834 & $-7,934$ & $-4,750$ & $-24,748$ & $-25,770$ \\
\hline Nonbank & 118,129 & 104,268 & 96,614 & 92,015 & 84,967 \\
\hline Ofwhich: & & & & & \\
\hline Prize bonds & 10,511 & 10,125 & -32 & 10,390 & 11,588 \\
\hline Federal Investment Bonds & $-10,227$ & $-7,943$ & $-2,474$ & $-6,228$ & 23,539 \\
\hline National Savings Schemes & 106,214 & 134,755 & 93,513 & 36,751 & 76,215 \\
\hline Privatization proceeds & 0 & 0 & 0 & 0 & 8,352 \\
\hline
\end{tabular}

Source: Ministry of Finance and Economic Affairs.

1/ Includes Islamic Development Bank. 
Table 20. Pakistan: Domestic Debt, 1997/98-2001/02 1/

(In millions of Pakistani rupees)

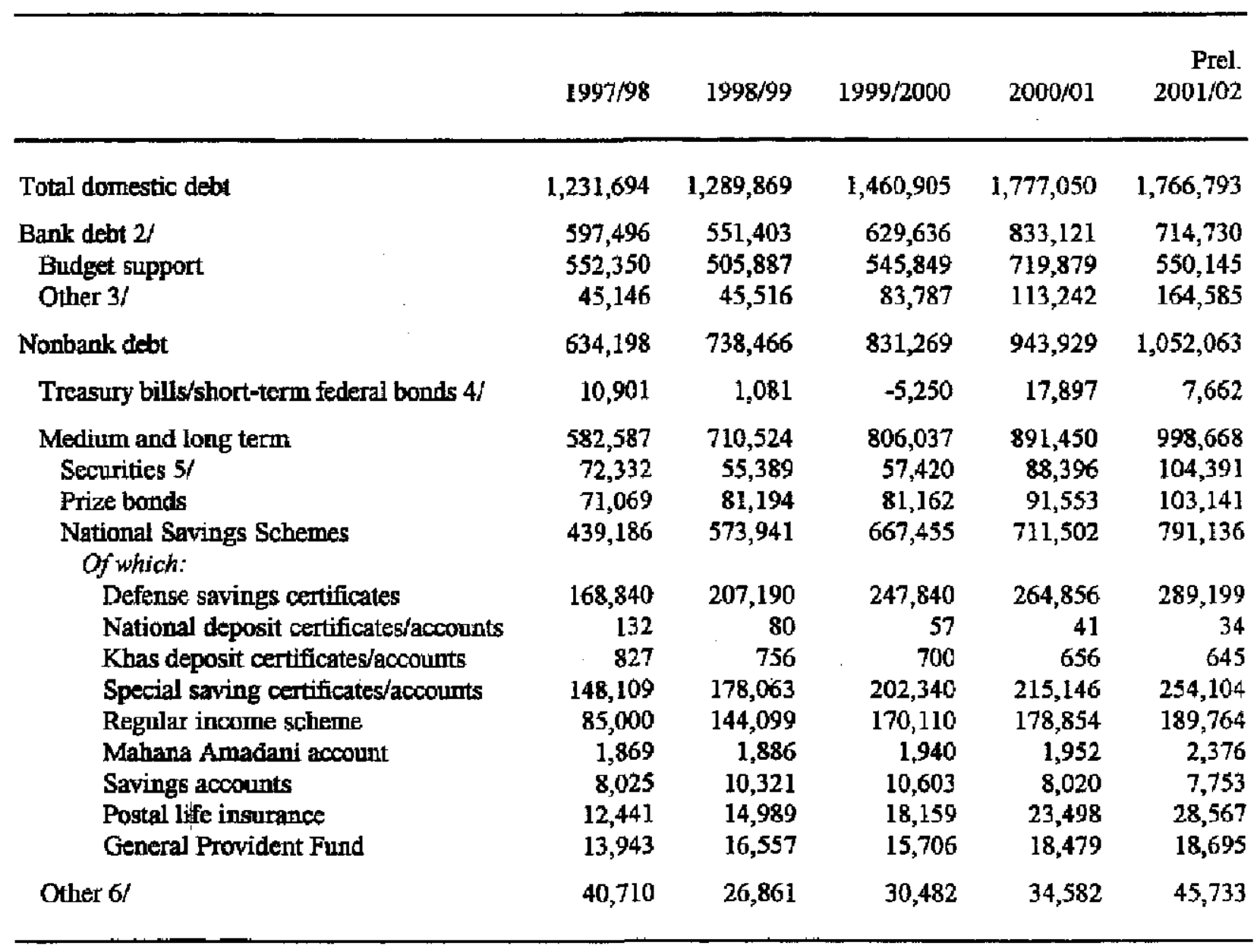

Source: Ministry of Finance and Economic Affairs.

$1 /$ End of period stocks.

2/ Net claims on government by the banking system.

3/ Includes commodity operations net of deposits of the Zakat and privatization funds.

4/ Derived as residual holdings. Can be negative due to valuations differing across holders.

5/ Comprises market loans, government bonds, federal investment bonds, and kational fund bonds.

6/ Includes public account deposits net of government deposits with NBFIs. 
Table 21. Pakistan: Accounts of the Water and Power Development Authority (Power Wing), $1997 / 98-2001 / 02$

(In millions of Pakistani rupees; unless otherwise indicated)

\begin{tabular}{|c|c|c|c|c|c|}
\hline & $1997 / 98$ & $1998 / 99$ & $1999 / 2000$ & $2000 / 01$ & $\begin{array}{l}\text { Prel. Est. } \\
2001 / 02\end{array}$ \\
\hline \multicolumn{6}{|l|}{ Main operational and financial indicators } \\
\hline International oil prices (U.S. dollar per barrel) & 15.1 & 12.6 & 23.7 & 26.3 & 22.1 \\
\hline Average exchange rate (Pakistani nupees per U.S. dollar) & 43.3 & 46.8 & 51.9 & 58.3 & 61.0 \\
\hline Average structural tariff increase (in percent) & 21 & 6.5 & -4.2 & 2.5 & 2.2 \\
\hline Units generated (in $\mathrm{GWh}$ ) & 53,261 & 53,683 & 56,259 & 58,416 & 60,849 \\
\hline Share of thermal units (in percent of units generated) & 58.6 & 58.2 & 65.7 & 70.6 & 68.7 \\
\hline Units purchased (in GWh) & 13,580 & 15,326 & 17,864 & 24,446 & 23,242 \\
\hline Technical and nontechnical losses 1/ & 26.0 & 27.5 & 27.3 & 25.7 & 25.8 \\
\hline Debt service coverage ratio $2 /$ & 0.9 & 1.6 & 0.9 & 0.6 & 0.2 \\
\hline Total receivables (as a percentage of billing) & 39.9 & 39.2 & 45.8 & 26.7 & 27.1 \\
\hline Public sector receivables (as a percentage of billing) & 73.7 & 81.7 & 115.0 & 59.6 & 61.4 \\
\hline Stock of payables to fuel suppliers and IPPs & 23,876 & 14,224 & 10,669 & 3,209 & 18,065 \\
\hline Administrative expenses increase (in percent) & 12.1 & $-14,0$ & 11.8 & 2.2 & 11.6 \\
\hline \multicolumn{6}{|l|}{ Summary cash flow statement } \\
\hline Total cash receipts (excluding GST, ED, \& W/Tax) & 98,319 & 127,546 & 129,560 & 159.598 & 177,409 \\
\hline Total cash outflows & 90,707 & 114,524 & 120,687 & 152,711 & 178,649 \\
\hline Purchase of power from IPPs & 53,148 & 42,532 & 54,150 & 84,612 & 109,101 \\
\hline Cost of fuel & 23,085 & 19,536 & 26,457 & 29,892 & 37,365 \\
\hline Debt service to GOP & 4,818 & 21,379 & 19,452 & 20,231 & 3,423 \\
\hline Debt service other than to GOP & 11,586 & 11,239 & 20,390 & 9,096 & 11,684 \\
\hline Hydel profit payment & 6,000 & 6,000 & 6,000 & 6,000 & 6,000 \\
\hline Operations and matntenance & 14,825 & 12,960 & 15,151 & 15,674 & 17,261 \\
\hline Other cash outflows & $-22,755$ & 878 & $-20,913$ & $-12,794$ & $-6,185$ \\
\hline Net cash available before investment program & 7,611 & 13,022 & 8,872 & 6,887 & $-1,240$ \\
\hline Investment program & 16,433 & 14,738 & 21,118 & 17,014 & 20,618 \\
\hline Foreign component & 8,822 & 7,270 & 12,246 & 10,127 & 13,034 \\
\hline Local component & 7,611 & 7,468 & 8,872 & 6,887 & 7,584 \\
\hline Cash surplus (+)/deficit (-) & 0 & 5,554 & 0 & 0 & $-8,824$ \\
\hline
\end{tabular}

Source: Pakistani authorities.

1/ Defined as units generated and purchased minus units sold, as a percentage of units generated and purchased.

2/ Net revenues divided by debt service requirements, as per definition agreed with the World Bank for the financial inprovement plan. 
Table 22. Pakistan: Accounts of the Karachi Electricity Supply Corporation, $1997 / 98-2001 / 2002$

(In millions of Pakistani rupees)

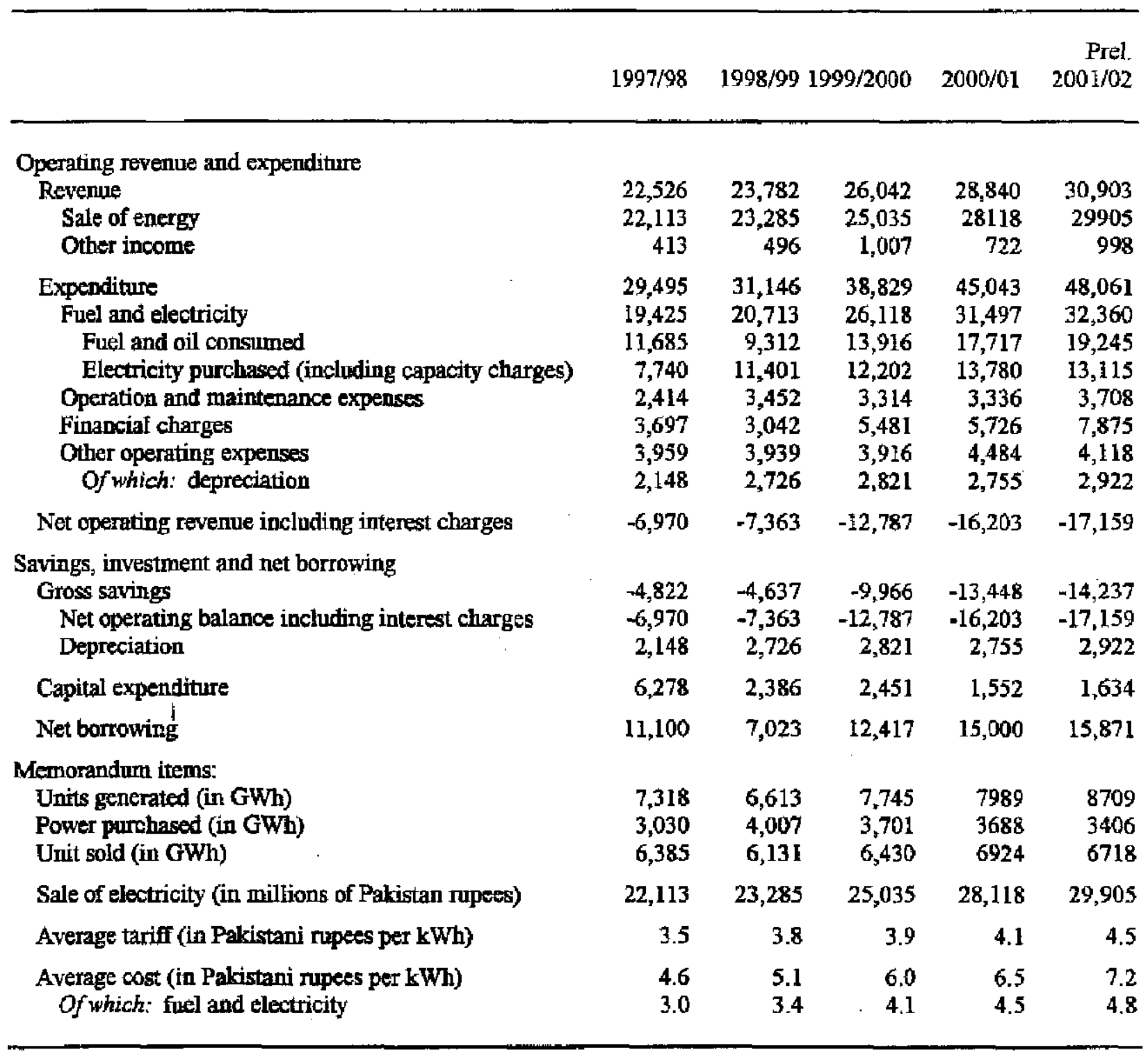

Source: Pakistani authorities. 
Table 23. Pakistan: Accounts of the Pakistan Railways, 1997/98-2001/02

(In millions of Pakistani rupees)

Prel.

$1997 / 98 \quad 1998 / 991999 / 2000 \quad 2000 / 01 \quad 2001 / 02$

\begin{tabular}{|c|c|c|c|c|c|}
\hline \multicolumn{6}{|l|}{ Operating revemue and expenditure } \\
\hline Revenue & 12,351 & 11,443 & 13,340 & 16,353 & 19,087 \\
\hline Revenue receipts & 9,698 & 9,292 & 9,572 & 11,953 & 13,087 \\
\hline Passengers & 4,500 & 4,447 & 4,779 & 5,602 & 6,438 \\
\hline Goods & 4,235 & 3,698 & 3,760 & 4,576 & 4,747 \\
\hline Others $1 /$ & 964 & 1,147 & 1,033 & 1,775 & 1,902 \\
\hline Transfers from the budget $2 /$ & 2,653 & 2,151 & 3,767 & 4,400 & 6,000 \\
\hline Expenditure & 14,528 & 15,215 & 15,537 & 17,080 & 17,268 \\
\hline Operating expenditure & 11,848 & 11,892 & 12,395 & 13,877 & 13,627 \\
\hline Of which: salaries and pensions & & 6,327 & 6,657 & 7,206 & 7,490 \\
\hline Interest charges & 2,680 & 3,323 & 3,142 & 3,203 & 3,641 \\
\hline Net operating balance including interest charges & $-2,177$ & $-3,772$ & $-2,197$ & -727 & 1,819 \\
\hline \multicolumn{6}{|l|}{ Savings, irvestment, and net borrowing } \\
\hline Gross savings & $-2,177$ & $-3,772$ & $-2,197$ & -727 & 1,819 \\
\hline Net operating balance including interest charges & $-2,177$ & $-3,772$ & $-2,197$ & .727 & 1,819 \\
\hline Capital expenditure & 2,219 & 3,450 & 457 & 2,553 & 5,329 \\
\hline Net borrowing & 4,395 & 7,222 & 2,654 & 3,280 & 3,510 \\
\hline \multicolumn{6}{|l|}{ Memorandum items: } \\
\hline \multicolumn{6}{|l|}{ Passenger traffic } \\
\hline Number of passengers (in million) & 64.9 & 64.9 & 67,5 & 68.8 & 63.3 \\
\hline Number of kilometers travelled (in million) & 18,774 & 18,980 & 18,495 & 19,590 & 19,660 \\
\hline Average kilometer per passenger & 289 & 292 & 274 & 285 & 311 \\
\hline Average rate per passenger kilometer (in Pakistan rupees) & 0.24 & 0.23 & 0.26 & 0.29 & 0.33 \\
\hline \multicolumn{6}{|l|}{ Freight traffic } \\
\hline Number of tons (in thousands) & 6,000 & 5,500 & 4,800 & 5,890 & 5,720 \\
\hline Number of kilometers travelled (in million) & 4,443 & 3,967 & 3,612 & 4,520 & 4,465 \\
\hline Average kilometers per ton & 741 & 721 & 753 & 767 & 781 \\
\hline Average rate per ton per kilometer (in Pakistan rupees) & 0.95 & 0,93 & 1,04 & 1.01 & 1.06 \\
\hline Number of employees & 104,185 & 100,643 & 94,243 & 92,500 & 90,500 \\
\hline
\end{tabular}

Source: Pakistani anthorities.

1/ Includes public service obligation, which are transfers from the budget to cover the cost of public services provided by railways.

2/ Transfers from the budget to cover operational shortfalls. 
Table 24. Pakistan: Accounts of the Pakistan International Airlines, 1999-2002 1/ (In millions of Pakistani rupees)

\begin{tabular}{lrrrr}
\hline & & & & Proj. \\
& 1999 & 2000 & 2001 & 2002 \\
\hline Operating revenue and expenditure & & & & \\
$\quad$ Operating revenue & 35,492 & 39,228 & 43,905 & 45,528 \\
Operating expenditure & 38,202 & 44,470 & 45,887 & 43,372 \\
$\quad$ Operating costs & 35,870 & 42,033 & 43,452 & 41,165 \\
$\quad$ Of which: salaries and pensions & 7,988 & 7,766 & 8,086 & 8,979 \\
$\quad$ Ofwhich: fuel & 6,883 & 12,296 & 12,079 & 9,024 \\
Interest expenses & 2,332 & 2,437 & 2,435 & 2,207 \\
Net operating balance including interest charges & $-2,710$ & $-5,242$ & $-1,982$ & 2,156 \\
Savings, investment, and net borrowing & & & & \\
Gross savings & 989 & $-2,576$ & 978 & 5,250 \\
$\quad$ Net operating balance including interest charges & $-2,710$ & $-5,242$ & $-1,982$ & 2,156 \\
$\quad$ Other income (net) & 1,257 & 97 & 430 & 310 \\
$\quad$ Depreciation & 2,442 & 2,569 & 2,530 & 2,784 \\
Capital expenditure & 1,285 & 1,022 & 490 & 739 \\
Net borrowing & 296 & 3,598 & -488 & $-4,511$ \\
& & & & \\
\hline
\end{tabular}

Source: Pakistani authorities.

1/ Projection for 2002 as of August 2002. 
Table 25. Pakistan: Accounts of Pakistan Steel Mills, 1998/99-2001/02

(In millions of Pakistani rupees)

Prez.

$\begin{array}{llll}1998 / 99 & 1999 / 2000 & 2000 / 01 & 2001 / 02\end{array}$

\begin{tabular}{lrrrr} 
Operating revenue and expenditure & & & & \\
Operating revenue & 12,525 & 14,307 & 16,075 & 14,422 \\
Net sales & 12,525 & 14,307 & 16,075 & 14,422 \\
Operating expenditure & 13,616 & 15,710 & 17,140 & 15,702 \\
Raw material costs & 5,803 & 6,958 & 7,067 & 7,009 \\
Salaries and pensions & 3,741 & 3,912 & 3,038 & 2,747 \\
Depreciation & 820 & 771 & 736 & 699 \\
Other operating expenses & 2,991 & 3,652 & 4,957 & 3,878 \\
Interest charges & 261 & 417 & 1,342 & 1,369 \\
Net operating balance including interest charges & $-1,091$ & $-1,403$ & $-1,065$ & $-1,280$ \\
Savings, investment, and net borrowing & & & & \\
Gross savings & 140 & -43 & 795 & -69 \\
$\quad$ Net operating balance including interest charges & $-1,091$ & $-1,403$ & $-1,065$ & $-1,280$ \\
$\quad$ Other income & 411 & 589 & 1,124 & 512 \\
$\quad$ Depreciation & 820 & 771 & 736 & 699 \\
Capital expenditure & 134 & 58 & 23 & 200 \\
Net borrowing & -6 & 101 & -772 & 269 \\
Memorandum items: & & & & \\
Tons of stecl produced (in thousands) & $\mathbf{8 3 4}$ & 1,001 & 944 & $\mathbf{8 8 2}$ \\
Tons of steel sold (in thousands) & 759 & 830 & 921 & 796 \\
Number of enployees & 20,625 & 16,102 & 14,407 & 13,625 \\
\hline
\end{tabular}

Source: Pakistani authorities. 
Table 26. Pakistan: Monetary Survey, 1997/98-2001/02

(End-of-period stocks; in billions of Pakistani rupees)

\begin{tabular}{|c|c|c|c|c|c|}
\hline & $1997 / 98$ & $1998 / 99$ & $1999 / 2000$ & $2000 / 01$ & $\begin{array}{r}\text { Prel. } \\
2001 / 02\end{array}$ \\
\hline $\begin{array}{l}\text { Net foreign assets } \\
\text { (in millions of U.S. dollars) }\end{array}$ & $\begin{array}{r}-90,1 \\
-1,958\end{array}$ & $\begin{array}{r}-70.7 \\
-1,376\end{array}$ & $\begin{array}{r}-45.1 \\
-862\end{array}$ & $\begin{array}{r}26.3 \\
411\end{array}$ & $\begin{array}{l}231,0 \\
3,845\end{array}$ \\
\hline Net domestic assets & $1,296.4$ & $1,351.3$ & $1,445.7$ & $1,499.7$ & $1,527,3$ \\
\hline $\begin{array}{l}\text { Net claims on government } \\
\text { Budgetary support }\end{array}$ & $\begin{array}{l}597.5 \\
552.4\end{array}$ & $\begin{array}{l}551.4 \\
505.9\end{array}$ & $\begin{array}{l}616.0 \\
532.2\end{array}$ & $\begin{array}{l}569.7 \\
499.9\end{array}$ & $\begin{array}{l}591.8 \\
514.1\end{array}$ \\
\hline Federal government & 565.7 & 527.2 & 558.3 & 552.5 & 592.6 \\
\hline Provincial governments & -13.4 & -21.3 & -26.1 & -52.6 & -78.4 \\
\hline Commodity operations & 63.7 & 67.3 & 107.4 & 95.3 & 100.6 \\
\hline Zakat deposits & -17.3 & -20.9 & -23.2 & -24.7 & -22.6 \\
\hline Privatization Fund & -1.2 & -0.9 & -0.4 & -0.8 & -0.4 \\
\hline Credit to the nongovernment sector & 697.5 & 816.7 & 842.8 & 902.6 & 921.6 \\
\hline Private sector $1 /$ & 632.0 & 734.7 & 753.2 & 802.1 & 838.2 \\
\hline Public enterprises (including autonomous boties) 2 & 65.5 & 82.0 & 89.6 & 100.5 & 83.5 \\
\hline Privatization account & -2.9 & -2.9 & -2.9 & -2.9 & -2.9 \\
\hline Other items (net) & 4.3 & -13.9 & -10.1 & 30.4 & 16.8 \\
\hline Domestic liquidity & $1,206.3$ & $1,280.5$ & $1,400.6$ & $1,526.0$ & $1,758.3$ \\
\hline Currency & 272.9 & 287.7 & 355.7 & 375.5 & 433.8 \\
\hline Paksitan rupee deposits & 654.8 & 844.2 & 932.5 & 996.4 & $1,167,0$ \\
\hline Demand deposits & 207.4 & 327.6 & 383.4 & 386.0 & 440.0 \\
\hline Tirne and savings deposits & 447.4 & 516.6 & 549.1 & 610.9 & 727.1 \\
\hline Foreign Currency Deposits (residents) & 278.6 & 148.7 & 112.5 & 154.2 & 157.5 \\
\hline Memorandum items: & & & & & \\
\hline Annual growth rate of domestic liquidity (in percent) & 14.5 & 6.2 & 9.4 & 9.0 & 15.2 \\
\hline Velocity of money (nominal GDP/domestic liquidity) & 2.2 & 2.3 & 2.2 & 2.2 & 2.1 \\
\hline Nominal GDP & $2,677.7$ & $2,913.5$ & $3,147,2$ & $3,416.3$ & $3,726.6$ \\
\hline
\end{tabular}

Source: State Bank of Pakistan.

1/ Claims on private sector have been adjusted from June 1998 to exclude loan loss provisions. 2/ Net of debt relief deposits. 
Table 27. Pakistan: Accounts of the State Bank of Pakistan, 1997/98-2001/02

(End-of-period stocks; in billions of Pakistani rupees)

\begin{tabular}{|c|c|c|c|c|c|}
\hline & $1997 / 98$ & $1998 / 99$ & $1999 / 2000$ & $2000 / 01$ & $\begin{array}{r}\text { Prel. } \\
2001 / 02\end{array}$ \\
\hline $\begin{array}{l}\text { Net foreign assets } \\
\text { (In millions of US dollars) }\end{array}$ & $\begin{array}{r}-48.6 \\
-1,057\end{array}$ & $\begin{array}{l}-42.5 \\
-826\end{array}$ & $\begin{array}{r}-55.6 \\
-1,063\end{array}$ & $\begin{array}{l}-19.1 \\
-299\end{array}$ & $\begin{array}{l}133.7 \\
2,225\end{array}$ \\
\hline Net domestic assets & 418.1 & 440.4 & 553.4 & 552,3 & 449.7 \\
\hline Net claims on government & 223.7 & 257.8 & 369.0 & 335.6 & 226.2 \\
\hline Budgetary Support & 242.2 & 279.6 & 392.7 & 361.1 & 249.2 \\
\hline Central government & 235.5 & 279.7 & 387.3 & 377.1 & 273.9 \\
\hline Provincial governments & 6.7 & -0.1 & 5.4 & -16.0 & -24.7 \\
\hline Privatization fund & -1.2 & -0.9 & -0.4 & -0.8 & -0.4 \\
\hline Zakat fund & -17.3 & -20.9 & -23.2 & -24.7 & -22.6 \\
\hline Claims on nongovernment sectors & 40.8 & 56.1 & 51.2 & 40.1 & 22.7 \\
\hline Private sector & 40.8 & 59.6 & 59.9 & 52.2 & 37.7 \\
\hline Public sector enterprises & 0.1 & 0.1 & 0.2 & 0.2 & 0.2 \\
\hline Special $a / c$ for debt relief (PSEs) & 0.0 & -3.7 & -8.9 & $-12,2$ & -15.2 \\
\hline Claims on scheduled banks & 158.5 & 187.2 & 193.4 & 198.0 & 198.9 \\
\hline Outstanding balance in privatization account & -2.9 & -2.9 & -2.9 & -2.9 & -2.9 \\
\hline Other items net & $-2.0^{\circ}$ & -57.7 & -57.3 & -18.4 & 4.8 \\
\hline Reserve money & 369.5 & 398.0 & 497.8 & 533,2 & 583.4 \\
\hline Banks reserves & 71.4 & 85.2 & 114.7 & 127.3 & 110.5 \\
\hline Private sector deposits & 6.4 & 6.2 & 8.0 & 11.3 & 12.6 \\
\hline Currency & 291.7 & 306.6 & 375.1 & 394.6 & 460.2 \\
\hline Outside scheduled banks & 272.9 & 287.7 & 355.7 & 375.5 & 433.8 \\
\hline Held by scheduled banks & 18.8 & 18.9 & 19.5 & 19.2 & 26.4 \\
\hline
\end{tabular}

Source: State Bank of Pakistan. 
Table 28. Pakistan: Accounts of the Scheduled Banks, 1997/98-2001/02

(End-of-period stocks; in billions of Pakistani rupees)

\begin{tabular}{lrrrrr}
\hline & & & & & \\
& $1997 / 98$ & $1998 / 99$ & $1999 / 2000$ & $2000 / 01$ & $2001 / 02$ \\
\hline Net foreign assets & & & & & \\
Net domestic assets & -41.4 & -28.3 & 10.5 & 45.4 & 97.3 \\
Net claims on government & 968.4 & $1,014.9$ & $1,026.5$ & $1,093.9$ & $1,214.5$ \\
Budgetary support & 373.8 & 293.6 & 246.9 & 234.1 & 365.6 \\
$\quad$ Central government & 310.1 & 226.3 & 139.5 & 138.8 & 265.0 \\
Provincial governments & 330.3 & 247.5 & 171.0 & 175.4 & 318.7 \\
Commodity operations & -20.1 & -21.2 & -31.5 & -36.6 & -53.7 \\
Claims on nongovernment sectors & 63.7 & 67.3 & 107.4 & 95.3 & 100.6 \\
Private sector & 656.7 & 760.6 & 791.6 & 862.5 & 898.9 \\
Public sector enterprises & 591.3 & 675.0 & 693.3 & 750.0 & 800.5 \\
Net claims on SBP & 65.4 & 85.6 & 98.2 & 112.5 & 98.5 \\
Liabilities to the SBP & -68.3 & -83.1 & -59.2 & -51.5 & -62.0 \\
Required/excess reserves & -158.5 & -187.2 & -193.4 & -198.0 & -198.9 \\
Currency held by schednled banks & 71.4 & 85.2 & 114.7 & 127.3 & 110.5 \\
Other irems net & 18.8 & 18.9 & 19.5 & 19.2 & 26.4 \\
Liabilities to private sector & 6.3 & 43.8 & 47.2 & 48.8 & 12.0 \\
Pakistari rupee deposits & 927.0 & 986.6 & $1,037.0$ & $1,139.3$ & $1,311.8$ \\
Demand deposits & 648.4 & 865.7 & 924.5 & 985.1 & $1,154.4$ \\
Time deposits & 201.0 & 349.1 & 375.4 & 374.7 & 427.3 \\
Residents' foreign currency acconnts & 447.4 & 516.6 & 549.1 & 610.5 & 727.1 \\
& 278.6 & 148.7 & 112.5 & 154.2 & 157.5 \\
\hline
\end{tabular}

Source: State Bank of Pakistan. 
Table 29. Pakistan: Credit to the Economy, 1997/98-2001/02

\begin{tabular}{|c|c|c|c|c|c|}
\hline & $1997 / 98$ & $1998 / 99$ & $1999 / 2000$ & $2000 / 01$ & $\begin{array}{r}\text { Prel. } \\
2001 / 02\end{array}$ \\
\hline & \multicolumn{5}{|c|}{ (End-of-period stocks; in millions of Pakistani rupees) } \\
\hline Total credit & 697,496 & 816,710 & 842,752 & 902,603 & $921, \$ 97$ \\
\hline SBP & 40,835 & 59,729 & 60,091 & 52,357 & 37,877 \\
\hline Commercial banks & 558,199 & 643,652 & 666,452 & 732,337 & 757,709 \\
\hline $\begin{array}{l}\text { Cotton export corporation } \\
\text { Export finance } \\
\text { Self employment scheme } \\
\text { Commercial credit }\end{array}$ & $\begin{array}{r}1,649 \\
54,886 \\
10,992 \\
490,672\end{array}$ & $\begin{array}{r}968 \\
80,932 \\
9,430 \\
552,322\end{array}$ & $\begin{array}{r}1,318 \\
72,571 \\
8,104 \\
584,459\end{array}$ & $\begin{array}{r}1,124 \\
73,364 \\
7,411 \\
650,438\end{array}$ & $\begin{array}{r}1,226 \\
60,026 \\
7,027 \\
689,430\end{array}$ \\
\hline Specialized banks & 98,462 & 113,329 & 116,209 & 117,909 & 126,011 \\
\hline $\begin{array}{l}\text { ADBP } \\
\text { DBP } \\
\text { FBC/PPCB }\end{array}$ & $\begin{array}{r}74,913 \\
18,206 \\
5,343\end{array}$ & $\begin{array}{r}87,139 \\
20,818 \\
5,372\end{array}$ & $\begin{array}{r}90,143 \\
21,130 \\
4,934\end{array}$ & $\begin{array}{r}89,517 \\
23,522 \\
4,870\end{array}$ & $\begin{array}{r}96,589 \\
24,253 \\
5,169\end{array}$ \\
\hline FBC/PPCB & \multicolumn{5}{|c|}{ (Annual percentage changes) } \\
\hline Total credit & 15.7 & 17.1 & 3.2 & 7.1 & 2.1 \\
\hline $\begin{array}{l}\text { Commercial banks } \\
\text { Of which: }\end{array}$ & 17.8 & 15.3 & 3.5 & 9.9 & 3.5 \\
\hline Export finance & 30.8 & 47.5 & -10.3 & 1.1 & -18.2 \\
\hline Commercial credit & 17.7 & 12.6 & 5.8 & 11.3 & 6.0 \\
\hline Specialized banks & 12.8 & 15.1 & 2.5 & 1.5 & 6.9 \\
\hline \multicolumn{6}{|l|}{ Memorandum items: } \\
\hline Credit to public enterprises $1 / 2 / 3 /$ & 59,921 & 80,496 & 93,289 & 112,276 & 96,527 \\
\hline Of which: credit to WAPDA & 8,980 & 9,720 & 11,419 & 15,725 & 22,125 \\
\hline Of which: credit to KESC & 3,229 & 14,683 & 15,756 & 23,549 & 9,623 \\
\hline Of which: credit to PIA & 3,684 & 4,877 & 6,288 & 7,471 & 9,560 \\
\hline Of which: credit to Pakistan Steel Mills & 9,889 & 11,341 & 17,872 & 20,089 & 18,903 \\
\hline
\end{tabular}

Source: State Bank of Pakistan.

1/ Excluding debt relief deposits.

$2 /$ Credit to public enterprises was affected in 2001/02 by the debt for equity swap between KESC and the government.

3/ The list of public enterprises used for monetary statistics was significantly revised in early 2002. Data corresponding to the new list are not available prior to June 2001. 
Table 30. Pakistan: Disbursements of Mandatory Agricultural Credit, 1997/98-2001/02

(In millions of Pakistani rupees)

\begin{tabular}{|c|c|c|c|c|c|c|c|c|c|c|}
\hline \multirow[t]{2}{*}{. } & \multicolumn{2}{|c|}{$1997 / 98$} & \multicolumn{2}{|c|}{ 1998/99 } & \multicolumn{2}{|c|}{$1999 / 2000$} & \multicolumn{2}{|c|}{$2000 / 01$} & \multicolumn{2}{|c|}{$\frac{\text { Prel. }}{2001 / 02}$} \\
\hline & Target & Actual & Target & $\overline{\text { Actual }}$ & Target & Actual & Target & Actual & Target & Actual \\
\hline Total disbursements & 41,456 & 32,974 & 44,806 & 42,847 & 52,922 & 39,688 & 49,264 & 44,035 & 60,000 & 52,455 \\
\hline ADBP $1 /$ & 26,300 & 22,354 & 28,510 & 30,171 & 35,000 & 24,424 & 31,250 & 27,610 & 35,000 & 29,108 \\
\hline $\mathrm{FBC} 2 /$ & 4,300 & 4,929 & 5,440 & 5,440 & 5,980 & 5,951 & 6,072 & 4,369 & 6,000 & 5,273 \\
\hline Commercial banks & 10,856 & 5,691 & 10,856 & 7,236 & 11,942 & 9,313 & 11,942 & 12,056 & 19,000 & 18,074 \\
\hline $\begin{array}{l}\text { Mernorandum item: } \\
\text { Lending rate (in per }\end{array}$ & ent) & 14.0 & & 14.0 & & 14.0 & & 14.0 & & 14.0 \\
\hline
\end{tabular}

Source: State Bank of Pakistan.

1/ Agricultural Development Bank of Pakistan.

2/ Federal Bank for Cooperatives. 
Table 31. Pakistan: Market Share of Banks, 1997/98-2001/02 1/

(In percent)

\begin{tabular}{|c|c|c|c|c|c|}
\hline & $1997 / 98$ & $1998 / 99$ & $1999 / 2000$ & $2000 / 01$ & $\begin{array}{r}\text { Prel. } \\
2001 / 02\end{array}$ \\
\hline \multicolumn{6}{|l|}{ Deposit market share $2 /$} \\
\hline Nationalized commercial banks & 45.9 & 46.1 & 47.8 & 45.1 & 46.4 \\
\hline Habib Bank Limited & 18.6 & 18.5 & 18.9 & 18.6 & 18.4 \\
\hline National Bank of Pakistan & 18.3 & 18.3 & 18.8 & 17.8 & 18.6 \\
\hline United Bank Limited & 8.7 & 9.1 & 9.9 & 8.3 & 9.0 \\
\hline First Women Bank & 0.3 & 0.2 & 0.2 & 0.4 & 0.4 \\
\hline Partially privatized banks & 18.1 & 20,8 & 20.0 & 20.3 & 19.4 \\
\hline Muslim Commercial Bank & 11.9 & 11.7 & 11.6 & 12.3 & 12.0 \\
\hline Allied Bank Limited & 6.2 & 9.1 & 8.4 & 8.0 & 7.4 \\
\hline Specialized banks & 1.0 & 1.4 & 1.4 & 0.0 & 0.0 \\
\hline Domestic private banks & 12.6 & 14.3 & 14.7 & 17.3 & 20.3 \\
\hline Branches of foreign banks & 22.4 & 17.5 & 16,0 & 17.2 & 13.9 \\
\hline \multicolumn{6}{|l|}{ Loan market share 3 / } \\
\hline Nationalized commercial banks & 42.4 & 42.4 & 42.9 & 43.0 & 42.1 \\
\hline Habib Bank Limited & 17.3 & 19.1 & 18.5 & 17.8 & 16.7 \\
\hline National Bank of Pakistan & 16.8 & 16.6 & 17.1 & 17.4 & 18.7 \\
\hline United Bank Limited & 8.2 & 6.6 & 7.2 & 7.7 & 6.6 \\
\hline First Women Bank & 0.1 & 0.1 & 0.1 & 0.1 & 0.1 \\
\hline Partially privatized banks & 15.2 & 15.7 & 16.5 & 15.5 & 13.8 \\
\hline Muslim Commercial Bank & 9.9 & 8.4 & 8.7 & 8.8 & 7.7 \\
\hline Allied Bank Limited & 5.3 & 7.3 & 7.8 & 6.7 & 6.1 \\
\hline Specialized banks & 14.2 & 13.8 & 13.0 & 12.3 & 12.6 \\
\hline Domestic private banks & 11.1 & 13.3 & 13.6 & 15.3 & 18.7 \\
\hline Branches of foreign banks & 17.1 & 14.8 & 14.0 & 13.9 & 12.8 \\
\hline
\end{tabular}

Source: State Bank of Pakistan.

1/ Based on end-June data

2/ Deposits include barks' liabilities to the nongovernment sector plus deposits of the federal and provineial governments.

$3 /$ Includes lending to the private sector, public enterprises, and autonomous bodies. 
Table 32. Pakistan: Nonperforming Loans of Banks and Development Finance Institutions, 1998-2002 (End-Jone)

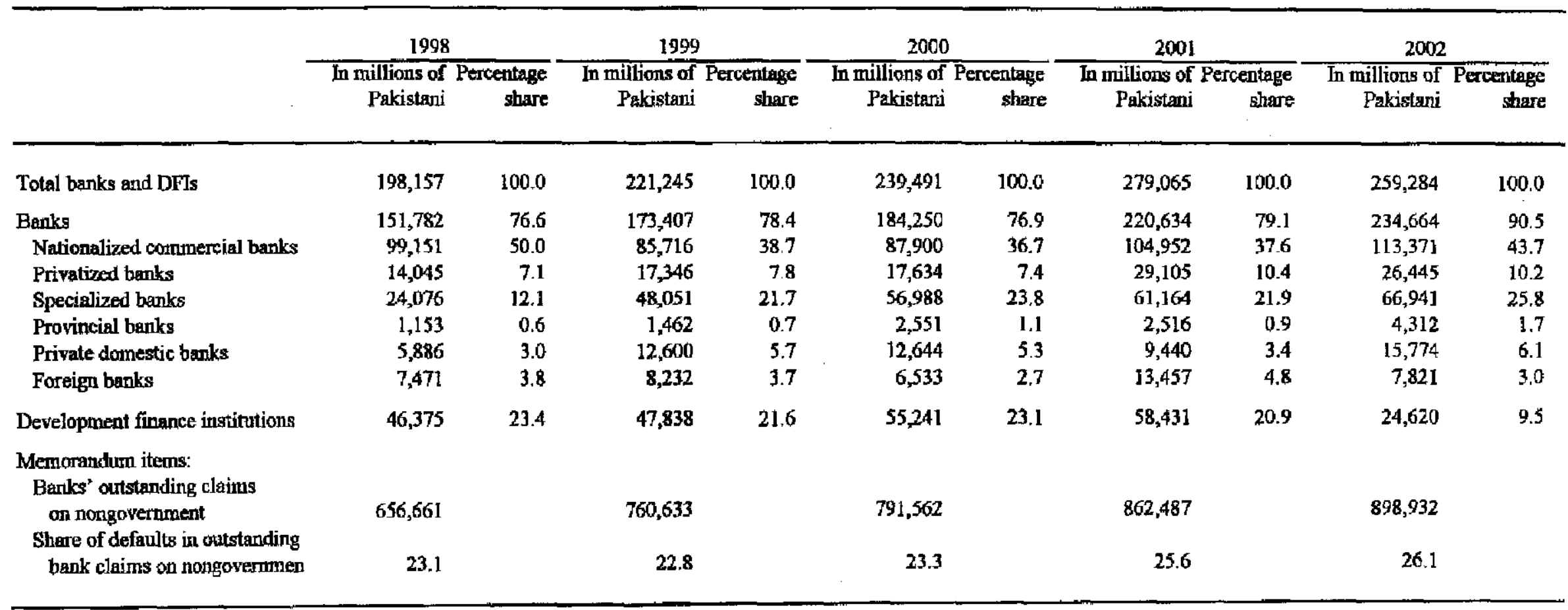

Source: State Bank of Pakistan 
Table 33. Pakistan: Major Interest Rates, 1997/98-2001/02

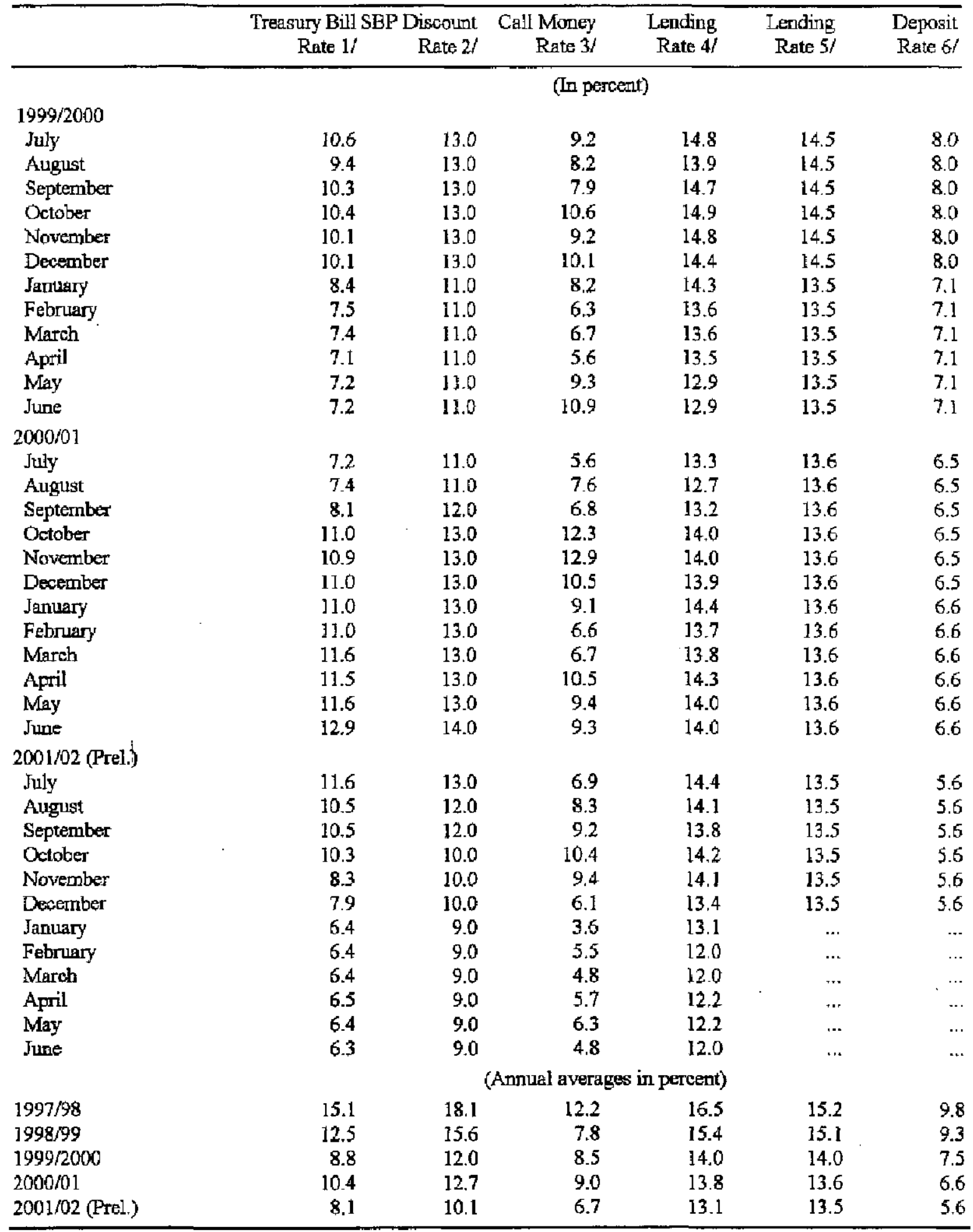

Source: State Bank of Pakistan.

1/ Primary auction rate on six-month treasury bills.

2/ SBP discount rate for its three-day repo facility.

3/Defined as the monthly average of daily minimum and maximum rates.

4/ Weighted average of lending rates for all commercial banks based on gross disbursement.

5/ Weighted average of lending rates for all commercial banks based on stock data.

$6 /$ Average rate of return on deposits under the profit and loss sharing system determined on a six-monthly basis. 
Table 34. Pakistan: Balance of Payments, 1997/98-2001/02

\begin{tabular}{|c|c|c|c|c|c|}
\hline & $1997 / 98$ & $1998 / 99$ & $1999 / 2000$ & $2000 / 01$ & $\begin{array}{r}\text { Prel. } \\
2001 / 02\end{array}$ \\
\hline & \multicolumn{5}{|c|}{ (In millions of U.S. dollars) } \\
\hline Current account (excluding official transfers) & $-1,922$ & $-2,699$ & $-2,121$ & $-1,951$ & 32 \\
\hline Current account balance (including official transfers) & $-1,702$ & $-2,126$ & $-1,195$ & $-1,112$ & 1,500 \\
\hline Trade balance & $-1,868$ & $-2,085$ & $-1,411$ & $-1,268$ & -360 \\
\hline Exponts f.o.b. & 8,433 & 7,528 & 8,191 & 8,934 & 9,133 \\
\hline Imports f.o.b. & $-10,301$ & $-9,613$ & $-9,602$ & $-10,202$ & $-9,493$ \\
\hline Services (net) & $-3,264$ & $-2,619$ & $-2,708$ & $-3,143$ & $-2,62 l$ \\
\hline Of which: interest payments & $-1,844$ & $-1,494$ & $-1,623$ & $-1,657$ & $-1,573$ \\
\hline Private transfers (net) & 3,210 & 2,005 & 1,997 & 2,460 & 3,013 \\
\hline Official transfers (net) & 220 & 573 & 926 & 839 & 1,468 \\
\hline Capital account & 1,421 & -801 & $-2,697$ & -623 & $-2,234$ \\
\hline Public medium- and long-term capital & 1,150 & 342 & $-1,488$ & -652 & $-1,495$ \\
\hline Project and nonproject loans & 875 & 241 & -664 & -332 & -864 \\
\hline Disbursements & 2,617 & 2,279 & 1,304 & 1,463 & 643 \\
\hline Of which: nonproject financing & 625 & 550 & 125 & 678 & 0 \\
\hline Amortization & $-1,742$ & $-2,038$ & $-1,968$ & $+1,795$ & $-1,507$ \\
\hline Commercial banks and IDB (net) & 399 & -370 & -170 & -76 & -224 \\
\hline Other & -124 & 471 & -654 & -244 & -407 \\
\hline Public sector short-term (net) & 173 & -968 & -221 & -59 & $+1,062$ \\
\hline Private medium- and long-ierm & 735 & 684 & 273 & 343 & -95 \\
\hline Of which: FDI & 601 & 472 & 471 & 322 & 369 \\
\hline Private short-term (including errors \& omissions) & -637 & -858 & $-1,261$ & -256 & 418 \\
\hline Overall balance \{before debt relief ) & -281 & $-2,927$ & $-3,892$ & $-1,735$ & -734 \\
\hline Financing & 281 & 2,927 & 3,892 & 1,735 & 734 \\
\hline Reserve assets (increase -) & 148 & $-1,254$ & 208 & $-1,088$ & $-3,079$ \\
\hline State Bank of Pakistan (including FE-25s) & 194 & -807 & 379 & -729 & $-2,716$ \\
\hline Deposit money banks & -46 & -447 & -171 & -359 & -363 \\
\hline Fund repurchases & 133 & 430 & -287 & -194 & -194 \\
\hline Net exceptional financing & 0 & 3,751 & 3,972 & 3,017 & 4,007 \\
\hline Arrears (increase +) & 0 & 0 & 343 & -525 & 0 \\
\hline Rescheduling $1 /$ & 0 & 2,240 & 1,750 & 1,587 & 1,210 \\
\hline Rescheduling conmercial bank debt & 0 & 834 & 152 & 0 & 0 \\
\hline Rollover of foreign deposits with banking system $2 /$ & 0 & 1,512 & 1,872 & 1,676 & 1,314 \\
\hline Program financing from IFIs & 0 & 0 & 7 & 279 & 1,367 \\
\hline \multirow[t]{2}{*}{ Privatization receipts } & 0 & 0 & 0 & 0 & 117 \\
\hline & \multicolumn{5}{|c|}{ (In percent of GDP) } \\
\hline \multicolumn{6}{|l|}{ Memorandum items: } \\
\hline Current account (excluding official transfers) & -3.6 & -4.7 & -3.9 & -3.3 & 0.1 \\
\hline Current account balance (including official transfers) & -3.2 & -3.7 & -2.2 & -1.9 & 2.5 \\
\hline Exponts f.o.b. (growth rate, percent) & 4.2 & $\cdot 10.7$ & 8.8 & 9.1 & 2.2 \\
\hline Lmports fo.b. (growth rate, percent) & -8.4 & -6.7 & -0.1 & 6.2 & -6.9 \\
\hline End-period gross official reserves $3 /$ & 940 & 1,680 & 908 & 1,679 & 4,329 \\
\hline (In weeks of next year juports of goods and nonfactor services) & 4.2 & 7.4 & 3.8 & 7.5 & 17.5 \\
\hline
\end{tabular}

Sources: State Bank of Pakistan; Ministry of Finance; and Fund staff estimates.

1/ Includes rescheduling of bilateral debt in 1999 and 2001, and rescheduling of commercial bank credit and Eurobonds in 1999.

2/ Includes rollover of FE-45 deposits with the banking system, of Kuwaif's and U.A.E.'s deposits with the SBP and, Bank of China's deposits with the NBP.

3/ Excluding gold, foreign currency deposits held with the SBP, and net of outstanding short-tern foreign currency swap and forward contracts. 
Table 35. Pakistan: Merchandise Exports, 1997/98-2001/02

\begin{tabular}{|c|c|c|c|c|c|}
\hline & $1997 / 98$ & $1998 / 99$ & $1999 / 2000$ & $2000 / 01$ & $\begin{array}{r}\text { Prel. } \\
2001 / 02\end{array}$ \\
\hline & \multicolumn{5}{|c|}{ (In millions of U.S. Dollars) } \\
\hline Total exports, balance of payments basis fo.b. & 8,433 & 7,528 & 8,191 & 8,934 & 9,133 \\
\hline Total exports, customs basis & 8,651 & 7,779 & 8,569 & 9,202 & 9,124 \\
\hline Cotton & 126 & 2 & 73 & 139 & 25 \\
\hline Rice & 562 & 533 & 540 & $\$ 26$ & 441 \\
\hline Basmati rice & 253 & 283 & 291 & 237 & 255 \\
\hline Other varieties & 309 & 251 & 249 & 289 & 186 \\
\hline Petroleum products & 45 & 47 & 82 & 95 & 112 \\
\hline Cotton manufactures & 4,866 & 4,538 & 5,092 & 5,211 & 5,386 \\
\hline Yarn & 1,160 & 945 & 1,072 & 1,074 & 942 \\
\hline Cloth & 1,250 & 1,115 & 1,096 & 1,033 & 1,133 \\
\hline Ready-made garments & 747 & 651 & 772 & 827 & 882 \\
\hline Tents and canvas & 58 & 41 & 53 & 49 & 48 \\
\hline Hosiery & 697 & 742 & 887 & 911 & 842 \\
\hline Towels and other made-up articles & 955 & 1,044 & 1,213 & 1,318 & 1,540 \\
\hline Other traditional exports & 1,198 & 902 & 1,036 & 1,204 & 1,007 \\
\hline Leather & 208 & 178 & 175 & 233 & 239 \\
\hline Carpets & 200 & 203 & 264 & 289 & 233 \\
\hline Fish prodncts & 172 & 122 & 139 & 138 & 126 \\
\hline Synthetic textiles & 618 & 398 & 458 & 545 & 410 \\
\hline $\begin{array}{l}\text { Other exports } \\
\text { Of which: }\end{array}$ & 1,831 & 1,757 & 1,746 & 2,027 & 2,153 \\
\hline Leather gaiments and leather gloves & 343 & 334 & 339 & 413 & 360 \\
\hline Sports goods & 384 & 256 & 279 & 271 & 295 \\
\hline Surgical goods & 125 & 112 & 120 & 124 & 138 \\
\hline Fruits and vegetables & 90 & 107 & 122 & 101 & 103 \\
\hline \multirow[t]{2}{*}{ Adjustment for freight and valuation $1 /$} & -218 & -253 & -406 & -268 & 9 \\
\hline & \multicolumn{5}{|c|}{ (Annual percentage changes) } \\
\hline Total exports, f.o.b. & 4.2 & -10.7 & 8.8 & 9.1 & 2.2 \\
\hline Cotton & 310.7 & -98.2 & 3056.5 & 91.5 & -82.0 \\
\hline Rice & 20.0 & -5.2 & 1.2 & -2.5 & $-16,2$ \\
\hline Petroleum products & -44.9 & 5.4 & 72.7 & 16.0 & 17.9 \\
\hline Cotton manufactures & -2.5 & -6.7 & 12.2 & 2.3 & 3.4 \\
\hline Other traditional exports & 8.9 & -24.7 & 14,9 & 16.2 & -16.4 \\
\hline Other exports & 11.2 & -4.0 & -0.6 & 16.1 & 6.2 \\
\hline
\end{tabular}

Sources: Ministry of Commerce; and Ministry of Finance and Economic Affairs.

1/ Customs data may differ from the f.o.b. figures used in the balance of payments estimates, in terms of timing, coverage, and valuation. 
Table 36. Pakistan: Merchandise Imports, 1997/98-2001/02

\begin{tabular}{|c|c|c|c|c|c|}
\hline & $1997 / 98$ & $1998 / 99$ & $1999 / 2000$ & $2000 / 01$ & $\begin{array}{r}\text { Prel. } \\
2001 / 02\end{array}$ \\
\hline & \multicolumn{5}{|c|}{ (In millions of U.S. dollars) } \\
\hline Total imports, f.o.b. & 10,301 & 9,613 & 9,602 & 10,202 & 9,493 \\
\hline Freight and insurance & 918 & 844 & 803 & 877 & 816 \\
\hline Total imports, c.i.f. & 11,219 & 10,457 & 10,405 & 11,079 & 10,309 \\
\hline Petroleum products & 1,750 & 1,485 & 2,783 & 3,327 & 2,664 \\
\hline Crude oil & 453 & 431 & 790 & 1,362 & 1,147 \\
\hline Fuel oil, fo.b. & 536 & 432 & 906 & 821 & 665 \\
\hline Other petroleum products. fo.b. & 761 & 622 & 1,087 & 1,144 & 851 \\
\hline Wheat & 709 & 407 & 284 & 0 & 0 \\
\hline Fertilizer & 208 & 265 & 198 & 171 & 176 \\
\hline Edible oils & 768 & 824 & 414 & 327 & 389 \\
\hline Palm oil & 669 & 597 & 325 & 283 & 376 \\
\hline Soy oil & 99 & 227 & 88 & 44 & 13 \\
\hline Project-related imports & 859 & 1,013 & 611 & 605 & 446 \\
\hline Defense-related imports & 862 & 630 & 507 & 498 & 508 \\
\hline Other public sector imports & 285 & 260 & 215 & 270 & 342 \\
\hline Private sector imports & 5,691 & 5,546 & 5,369 & 5,599 & 5,711 \\
\hline \multirow[t]{2}{*}{ Other $1 /$} & 87 & 28 & 25 & 30 & 50 \\
\hline & \multicolumn{5}{|c|}{ (Annual percentage changes) } \\
\hline Total imports, c.j.f. & -8.1 & -6.8 & -0.5 & 6.5 & -7.0 \\
\hline Petrolewm products & -22.1 & -15.2 & 87.4 & 19.6 & -19.9 \\
\hline Wheat & 48,6 & -42.6 & -30.3 & -100.0 & $\ldots$ \\
\hline Fertilizers & -46.3 & 27.5 & -25.5 & -13.6 & 2.9 \\
\hline Edible oils & 25.7 & 7.3 & -49.8 & -20.9 & 19.0 \\
\hline Project-related & -18.0 & 17.9 & -39.7 & -1.0 & $-26: 3$ \\
\hline Defense-related imports & $-3,3$ & -26.9 & -19.5 & -1.8 & 2.0 \\
\hline Other public sector imports & -9.8 & -8.8 & -17.3 & 25.6 & 26.7 \\
\hline Private sector imports & -7.5 & -2.5 & -3.2 & 4.3 & 2.0 \\
\hline
\end{tabular}

Sources: Ministry of Commerœ, and Ministry of Finance and Economic Affairs.

1/ Includes Afghan refugee assistance. 
Table 37. Pakistan: Merchandise Trade by Economic Category, 1997/98-2001/02

\begin{tabular}{|c|c|c|c|c|c|}
\hline & $1997 / 98$ & $1998 / 99$ & $1999 / 2000$ & $2000 / 01$ & $\begin{array}{l}\text { Prel. } \\
2001 / 02\end{array}$ \\
\hline & \multicolumn{5}{|c|}{ (In millions of U.S. dollars) } \\
\hline Exports (f.o.b.) $1 /$ & 8,627 & 7,780 & 8,569 & 9,202 & 9,124 \\
\hline Primary commodities & 1,095 & 900 & 1,037 & 1,157 & 984 \\
\hline Semi-manufatured goods & 1,495 & 1,401 & 1,320 & 1,388 & 1,320 \\
\hline Manufactured goods & 6,037 & 5,479 & 6,212 & 6,657 & 6,819 \\
\hline Of which: Cotton manufactures & 4,866 & 4,538 & 5,092 & 5,210 & 5,368 \\
\hline Imports (c.i.f) $1 /$ & 10,118 & 9,437 & 10,361 & 10,729 & 10,336 \\
\hline Consumer goods & 1,805 & 1,484 & 1,461 & 1,536 & 1,172 \\
\hline Raw material for consumer goods & 4,534 & 4,465 & 5,585 & 5,917 & 5,658 \\
\hline Raw material for capital goods & 541 & 519 & 601 & 588 & 638 \\
\hline \multirow[t]{2}{*}{ Capital goods } & 3,238 & 2,969 & 2,715 & 2,688 & 2,868 \\
\hline & \multicolumn{5}{|c|}{ (In percent of total) } \\
\hline Exports (f.o.b) $1 /$ & 100.0 & 100.0 & 100.0 & 100.0 & 100.0 \\
\hline Primary commodities & 12.7 & 11.6 & 12.1 & 12.6 & 10.8 \\
\hline Semi-manufatured goods & 17.3 & 18.0 & 15.4 & 15.1 & 14.5 \\
\hline Manufactured goods & 70.0 & 70.4 & 72.5 & 72.3 & 74.7 \\
\hline Of which: Cotton manufactures & 56.4 & 58.3 & 59.4 & 56.6 & 58.8 \\
\hline Imports (c.i.f) $1 /$ & 100.0 & 100.0 & 100.0 & 100.0 & 100.0 \\
\hline Consumer goods & 17.8 & 15.7 & 14.1 & 14.3 & 11.3 \\
\hline Raw material for consumer goods & 44.8 & 47.3 & 53.9 & 55.1 & 54.7 \\
\hline Raw material for capital goods & 5.3 & 5.5 & 5.8 & 5.5 & 6.2 \\
\hline Capital goods & 32.0 & 31.5 & 26.2 & 25.1 & 27.7 \\
\hline
\end{tabular}

Source: Ministry of Commerce.

1/ On the basis of customs data, which may differ from the figures used in the balance of payments in terms of timing, coverage, and valuation. 
Table 38. Pakistan: Direction of Trade, 1997/98-2001/02

(In percent)

\begin{tabular}{lrrrrr}
\hline & & & & & Prel. \\
& $1997 / 98$ & $1998 / 99$ & $1999 / 2000$ & $2000 / 01$ & $2001 / 02$ \\
\hline & & & & & \\
\hline & 100.0 & 100.0 & 100.0 & 100.0 & 100.0 \\
Exports & 31.0 & 28.7 & 27.3 & 25.3 & 26.5 \\
UK & 7.0 & 6.6 & 6.8 & 6.3 & 7.4 \\
Other & 24.0 & 22.1 & 20.5 & 19.0 & 19.1 \\
United States & 21.0 & 21.8 & 24.8 & 24.4 & 24.6 \\
Japan & 4.0 & 3.5 & 3.1 & 2.1 & 1.9 \\
Hong Kong & 7.0 & 7.1 & 6.1 & 5.5 & 4.9 \\
Singapore & 1.0 & 0.5 & 0.6 & 0.5 & 0.5 \\
China & 2.0 & 2.0 & 2.1 & 3.3 & 2.5 \\
Other & 34.0 & 36.5 & 36.0 & 38.9 & 39.1 \\
Imports & 100.0 & 100.0 & 100.0 & 100.0 & 100.0 \\
European Community & 19.0 & 17.4 & 15.1 & 14.2 & 16.3 \\
UK & 4.0 & 4.4 & 3.5 & 3.3 & 3.5 \\
Other & 15.0 & 13.0 & 11.6 & 10.9 & 12.8 \\
United States & 11.0 & 7.7 & 6.3 & 5.3 & 6.7 \\
Japan & 8.0 & 8.3 & 6.3 & 5.4 & 4.9 \\
Hong Kong & 0.4 & 0.6 & 0.5 & 0.6 & 0.6 \\
Singapore & 2.0 & 3.5 & 2.6 & 3.0 & 3.1 \\
Ching & 5.0 & 4.2 & 4.6 & 4.9 & 4.5 \\
Other & 54.6 & 58.3 & 64.6 & 66.6 & 63.9 \\
& & & & & \\
\hline
\end{tabular}

Source: Federal Burean of Statistics 
Table 39. Pakistan: Services, Income, and Current Transfers, 1997/98-2001/02

(In millions of U.S. dollars)

\begin{tabular}{|c|c|c|c|c|c|}
\hline & $1997 / 98$ & $1998 / 99$ & $1999 / 2000$ & $2000 / 01$ & $\begin{array}{r}\text { Prel. } \\
2001 / 02\end{array}$ \\
\hline Services (nonfactor services and income) & $-3,264$ & $-2,619$ & $-2,708$ & $-3,143$ & $-2,621$ \\
\hline Nonfactor services & -934 & -811 & -776 & -983 & -312 \\
\hline Receipts & 1,584 & 1,314 & 1,385 & 1,350 & 1,914 \\
\hline Transportation & 804 & 681 & 787 & 828 & 823 \\
\hline Travel & 100 & 69 & 76 & 85 & 100 \\
\hline Other & 680 & 564 & 522 & 437 & 991 \\
\hline Payments & $-2,518$ & $-2,124$ & $-2,161$ & $-2,333$ & $-2,226$ \\
\hline Transportation & $-1,601$ & $-1,374$ & $-1,465$ & $-1,587$ & $-1,467$ \\
\hline Travel & -379 & -191 & -219 & -265 & -247 \\
\hline Other & -538 & -559 & -477 & -481 & -512 \\
\hline Income & $-2,330$ & $-1,808$ & $-1,932$ & $-2,160$ & $-2,309$ \\
\hline Receipts & 124 & 95 & 116 & 113 & 111 \\
\hline Interest on reserves & 96 & 75 & 105 & 96 & 98 \\
\hline Other & 28 & 20 & 11 & 17 & 13 \\
\hline Payments & $-2,454$ & $-1,903$ & $-2,048$ & $-2,273$ & $-2,420$ \\
\hline Interest & $-1,844$ & $-1,494$ & $-1,623$ & $-1,657$ & $-1,573$ \\
\hline Other & -610 & -409 & -425 & -616 & -847 \\
\hline Current transfers & 3,430 & 2,578 & 2,923 & 3,299 & 4,481 \\
\hline Private transfers & 3,210 & 2,005 & 1,997 & 2,460 & 3,013 \\
\hline Receipts | & 3,225 & 2,038 & 2,028 & 2,502 & 3,053 \\
\hline Remittances & 1,490 & 1,060 & 983 & 1,086 & 2,390 \\
\hline Other & 1,735 & 978 & 1,045 & 1,416 & 663 \\
\hline Payments & -15 & -33 & -31 & -42 & -40 \\
\hline Official transfers (net) & 220 & 573 & 926 & 839 & 1,468 \\
\hline Receipts & 224 & 577 & 940 & 842 & 1,472 \\
\hline Cash grants & & & & & 742 \\
\hline Project aid & 183 & 112 & 123 & 134 & 84 \\
\hline Commodity aid & & 379 & 791 & 683 & 579 \\
\hline Other & 41 & 86 & 26 & 25 & 68 \\
\hline Payments & 4 & -4 & -14 & -3 & -4 \\
\hline
\end{tabular}

Sources: State Bank of Pakistan; and Ministry of Finance. 
Table 40. Pakistan: Home Remittances from Pakistani Nationals Abroad, 1997/98-2001/02

(In millions of U.S. dollars)

\begin{tabular}{lrrrrr}
\hline & $1997 / 98$ & $1998 / 99$ & $1999 / 2000$ & $2000 / 01$ & $\begin{array}{r}\text { Prel } \\
2001 / 02\end{array}$ \\
\hline Total & 1,490 & 1,060 & 983 & 1,086 & 2,390 \\
Total cash flow & 1,238 & 876 & 913 & 1,021 & 2,342 \\
$\quad$ Middle East & 843 & 641 & 682 & 693 & 1,070 \\
United Kingdom & 99 & 74 & 73 & 81 & 152 \\
United States & 166 & 82 & 80 & 135 & 779 \\
Germany & 17 & 12 & 10 & 9 & 13 \\
Other & 113 & 67 & 67 & 103 & 328 \\
Encashment and Profits of & & & & & 48 \\
Bearer Certificates & 252 & 185 & 70 & 65 & 48 \\
\hline
\end{tabular}

Source: State Bank of Pakistan. 
Table 41. Pakistan: Medium- and Long-Term Capital Flows, 1997/98-2001/02 l/

(In millions of U.S. dollars)

\begin{tabular}{|c|c|c|c|c|c|}
\hline & $1997 / 98$ & $1998 / 99$ & $1999 / 2000$ & $2000 / 01$ & $\begin{array}{r}\text { Prel. } \\
2001 / 02\end{array}$ \\
\hline Total medium- and long-term capital & 1,736 & 2,463 & -185 & -115 & 406 \\
\hline Public and publicly guaranteed & 1,001 & 1,997 & -463 & -24 & 598 \\
\hline Project and nonproject aid & 726 & 1,647 & 324 & 295 & 1,228 \\
\hline Disbursements & 2,617 & 3,685 & 2,292 & 2,090 & 2,735 \\
\hline Project loans & 1,369 & 1,499 & 988 & 785 & 643 \\
\hline Food loans & 623 & 230 & 191 & 0 & 0 \\
\hline Program Joans $2 i$ & 625 & 1,956 & 1,113 & 1,305 & 2,092 \\
\hline Amortization & $1,89 !$ & 2,038 & 1,968 & 1,795 & 1,507 \\
\hline Commercial banks and IDB & 399 & -370 & -170 & -76 & -224 \\
\hline Commercial banks & 453 & -376 & -197 & -41 & -224 \\
\hline Disbursements & 595 & 0 & 0 & 100 & 300 \\
\hline Amortization & 142 & 376 & 197 & 141 & 524 \\
\hline IDB & -54 & 6 & 27 & -35 & 0 \\
\hline Disbursements & 0 & 14 & 27 & 0 & 0 \\
\hline Amortization & 54 & 8 & 0 & 35 & 0 \\
\hline Eurobonds and Foreign Exchange & -124 & 720 & -617 & -243 & -406 \\
\hline Bearer Certificates & -150 & 164 & -602 & 25 & -465 \\
\hline Credits & 0 & 208 & 8 & 39 & 19 \\
\hline Debits & 150 & 44 & 610 & 14 & 484 \\
\hline Other & 26 & 556 & -15 & -268 & 59 \\
\hline Credits & 58 & 933 & 7 & 6 & 80 \\
\hline Debits & 32 & 377 & 22 & 274 & 21 \\
\hline Private sector & 735 & 466 & 278 & -91 & -192 \\
\hline Private sector, nonbank & 733 & 466 & 280 & -88 & -191 \\
\hline Direct investment & 572 & 428 & 473 & 286 & 484 \\
\hline Inflows $\mathbf{3}$ / & 602 & 478 & 473 & 323 & 486 \\
\hline Outflows & 30 & 50 & 0 & 37 & 2 \\
\hline Portfolio investment & 221 & 28 & 73 & -140 & -8 \\
\hline Inflows & 221 & 28 & 73 & 0 & 0 \\
\hline Outflows & 0 & 0 & 0 & 140 & 8 \\
\hline Private unguaranteed & 373 & -241 & -422 & -303 & -347 \\
\hline Inflows & 797 & 195 & 166 & 192 & 185 \\
\hline Outflows & 424 & 436 & 588 & 495 & 532 \\
\hline Other nonbank & -433 & 251 & 156 & 69 & -320 \\
\hline Inflows & 31 & 251 & 161 & 69 & 0 \\
\hline Outflows & 464 & 0 & 5 & 0 & 320 \\
\hline Deposit money banks & 2 & 0 & -2 & -3 & -1 \\
\hline Inflows & 3 & 0 & 1 & 0 & 0 \\
\hline Outflows & 1 & 0 & 3 & 3 & 1 \\
\hline
\end{tabular}

Sources: State Bank of Pakistan; Ministry of Finance and Economic Affairs; and Fund staff estimates.

1/ The classification used in this table differs from the one in Table 34.

2/ Including exceptional financing.

$3 /$ Including privatization proceeds. 
Table 42. Pakistan: External Debt, 1997/98-2001/02

\begin{tabular}{|c|c|c|c|c|c|}
\hline & $1997 / 98$ & $1998 / 99$ & $1999 / 2000$ & $2000 / 01$ & $\begin{array}{r}\text { Prel. } \\
2001 / 02\end{array}$ \\
\hline & \multicolumn{5}{|c|}{ (In millions of U.S. dollars) } \\
\hline Total external debt & 33,561 & 34,062 & 34,063 & 36,156 & 36,007 \\
\hline Total public debt & 29,000 & 29,318 & 29,757 & 32,743 & 33,167 \\
\hline Medium- and long-term public and publicly guaranteed & 27,191 & 27,270 & 27,505 & 29,669 & 31,372 \\
\hline Project and nonproject aid (including military) & 24,048 & 24,105 & 24,792 & 26,647 & 28,199 \\
\hline Commercial banks and IDB & 1,100 & 730 & 560 & 634 & 383 \\
\hline Eurobonds and constnuction bonds & 628 & 610 & 620 & 865 & 840 \\
\hline Foreign Currency Bearer Certificates & 0 & 0 & 37 & 20 & 12 \\
\hline MMF & 1,415 & 1,825 & 1,496 & 1,503 & 1,939 \\
\hline Public sector short-term & 626 & 779 & 818 & 906 & 265 \\
\hline Commercial banks and IDB & 298 & 583 & 571 & 834 & 212 \\
\hline Foreign Exchange and Dollar Bearer Certificates & 328 & 196 & 147 & 72 & 53 \\
\hline State Bank of Pakistan (excluding IMF) & 1,183 & 1,270 & 1,435 & 2,169 & 1,530 \\
\hline \multirow[t]{2}{*}{ Private debt } & 4,561 & 4,744 & 4,306 & 3,412 & 2,840 \\
\hline & \multicolumn{5}{|c|}{ (In percent of GDP) } \\
\hline Total external debt & 62.8 & 59.9 & 62.5 & 61.7 & 59.2 \\
\hline Total public debt & 54.3 & 51.5 & 54.6 & 55.8 & 54.5 \\
\hline Medium- and long-term public and publicly guaranteed & 50.9 & 47.9 & 50.5 & 50.6 & 51.6 \\
\hline Project and nonproject aid (including military) & 45.0 & 42.4 & 45.5 & 45.4 & 46.4 \\
\hline Commercial banks and IDB & 2.1 & 1.3 & 1.0 & 1.1 & 0.6 \\
\hline Eurobonds and construction bonds & 1.2 & 1.1 & 1.1 & 1.5 & 1.4 \\
\hline Foreign Currency Bearer Certificates & 0.0 & 0.0 & 0.1 & 0.0 & 0.0 \\
\hline DMF & 2.6 & 3.2 & 2.7 & 2.6 & 3.2 \\
\hline Public sector shórt-term & 1.2 & 1.4 & 1.5 & 1.5 & 0.4 \\
\hline Commercial banks and IDB & 0.6 & 1.0 & 1.2 & 1.4 & 0.3 \\
\hline Foreign Exchange and Dollar Bearer Certificates & 0.6 & 0.3 & 0.3 & 0.1 & 0.1 \\
\hline State Bank of Pakistan (excluding IMF) & 2,2 & 2.2 & 2.6 & 3.7 & 2.5 \\
\hline Private debt (including FCAs) & 8.5 & 8.3 & 7.9 & 5.8 & 4.7 \\
\hline
\end{tabular}

Sources: State Bank of Pakistan; and Ministry of Finance. 
Table 43. Pakistan: Foreign Currency Deposits, 1997/98-2001/02

(End-of-period stocks, in millions of U.S. dollars; unless otherwise specified)

\begin{tabular}{|c|c|c|c|c|c|}
\hline & $1997 / 98$ & $1998 / 99$ & $1999 / 2000$ & $2000 / 01$ & $\begin{array}{r}\text { Prel. } \\
\text { 2001/02 }\end{array}$ \\
\hline Total foreign currency deposits & 9,679 & 5,465 & 3,921 & 3,796 & 3,291 \\
\hline $\begin{array}{l}\text { Residents' deposits } \\
\text { Of which: }\end{array}$ & 6,024 & 2,909 & 2,182 & 2,419 & 2,625 \\
\hline $\begin{array}{l}\text { Frozen accounts } \\
\text { New accounts }\end{array}$ & $\begin{array}{r}6,024 \\
\ldots\end{array}$ & $\begin{array}{r}2354 \\
555\end{array}$ & $\begin{array}{r}1303 \\
879\end{array}$ & $\begin{array}{l}1069 \\
1350\end{array}$ & $\begin{array}{r}770 \\
1855\end{array}$ \\
\hline $\begin{array}{l}\text { Nonresidents' deposits } \\
\text { Of which: }\end{array}$ & 3,655 & 2,556 & 1,739 & 1,377 & 666 \\
\hline Frozen accounts & 3,655 & 2,494 & 1,641 & 1,184 & 423 \\
\hline With domestic banks & 2,039 & 1,605 & 1,114 & 788 & 331 \\
\hline Institutional deposits & 772 & 953 & 784 & 570 & 213 \\
\hline Individual accounts & 1,267 & 652 & 330 & 218 & 118 \\
\hline With domestic nonbank financial institutions & 1,616 & 889 & 527 & 396 & 92 \\
\hline New accounts & $\ldots$ & 62 & 98 & 193 & 243 \\
\hline Memorandum items: & & & & & \\
\hline Share of resident FCDs in M2 deposits (percent) & 29.7 & 15.0 & 10.9 & 13.4 & 11.9 \\
\hline Share of resident FCDs in M2 (percent) & 23.0 & 11.7 & 8.1 & 10.1 & 9.0 \\
\hline
\end{tabular}

Source: State Bank of Pakistan. 
Table 44. Pakistan: Summary of Public Extemal Debt and Debt Service, 1997/98-2001/02

Prel.

$1997 / 98 \quad 1998 / 99 \quad 1999 / 2000 \quad 2000 / 01 \quad 2001 / 02$

Total public- and publicly-guaranteed external debt

Medium- and long-term debt

Project \& nonproject aid

Commercial banks and IDB

Other (including securities and frozen foreign currency accounts)

Short-term debt (by initial maturity)

Commercial banks and IDB

FËBCs and DBCs

SBP liabilities (inchuding swaps)

Fund credit and loans

Service of medium- and long-term public- and publichy-guaranteed debt Amortization Interest

Interest on public- and publicly-guaranteed short-term debt

Total public- and publicly-guaranteed external debt

Long-term

Of which: project and nonproject aid

Short-term

Fund credit and loans t

Service of medium- and long-term public- and publicly-guaranteed debt Amortization

Interest

Interest on public- and publicly-guaranteed short-term debt

Total public- and publicly-guaranteed external debt

Service of medium- and long-term public- and publicly-guaranteed debt

Amortization

Interest

Memorandum items:

Implicit interest on public- and publicly-guaranteed external debt

Public external debt service in percent of government revenue (incl. grants)

Total external debt

(In percent of GDP)
(In millions of U.S. dollars)

$\begin{array}{rrrrr}29,000 & 29,318 & 29,757 & 32,743 & 33,167 \\ 25,776 & 25,445 & 26,009 & 28,165 & 29,433 \\ 24,048 & 24,105 & 24,792 & 26,647 & 28,199 \\ 1,100 & 730 & 560 & 634 & 383 \\ 628 & 610 & 657 & 885 & 851 \\ 1,809 & 2,049 & 2,253 & 3,075 & 1,795 \\ 298 & 583 & 671 & 834 & 212 \\ 328 & 196 & 147 & 72 & 53 \\ 1,183 & 1,270 & 1,435 & 2,169 & 1,530 \\ 1,415 & 1,825 & 1,496 & 1,503 & 1,939 \\ 3,299 & 3,499 & 4,175 & 2,616 & 3,548 \\ 2,242 & 2,484 & 3,113 & 1,540 & 2,449 \\ 1,057 & 1,015 & 1,062 & 1,076 & 1,100 \\ 595 & 265 & 319 & 284 & 198 \\ & \text { (In percent of GDP) } & & \\ 54.3 & 51.5 & 54.6 & 55.8 & 54.5 \\ 48.3 & 44.7 & 47.8 & 48.0 & 48.4 \\ 45,0 & 42.4 & 45.5 & 45.4 & 46.4 \\ 3.4 & 3.6 & 4.1 & 5.2 & 3.0 \\ 2.6 & 3.2 & 2.7 & 2.6 & 3.2 \\ 6.2 & 6.1 & 7.7 & 4.5 & 5.8 \\ 4.2 & 4.4 & 5.7 & 2.6 & 4.0 \\ 2.0 & 1.8 & 1.9 & 1.8 & 1.8 \\ 1.1 & 0.5 & 0.6 & 0.5 & 0.3\end{array}$

(In percent of exports of goods and nonfactor services)

$\begin{array}{rrrrr}289.5 & 331.6 & 310.7 & 318.4 & 300.2 \\ 32.9 & 39.6 & 43.6 & 25.4 & 32.1 \\ 22.4 & 28.1 & 32.5 & 15.0 & 22.2 \\ 10.6 & 11.5 & 11.1 & 10.5 & 10.0 \\ & & & & \\ 5.7 & 4.4 & 4.7 & 4.4 & 3.9 \\ 39.1 & 37.0 & 44.2 & 25.7 & 31.0 \\ 33,561 & 34,052 & 34,063 & 36,156 & 36,007 \\ 62.8 & 59.9 & 62.5 & 61.7 & 59.2\end{array}$

Sources: State Bank of Pakistan; and Ministry of Finance 
Table 45. Pakistan: Public and Publicly Guaranteed Medium- and Long-Term Debt to Official Creditors, 1997/98-2001/02

(In millions of U.S. dollars)

\begin{tabular}{|c|c|c|c|c|c|c|c|c|c|c|c|c|c|c|c|}
\hline & \multicolumn{3}{|c|}{$1997 / 98$} & \multicolumn{3}{|c|}{ 1998/99 } & \multicolumn{3}{|c|}{$1999 / 2000$} & \multicolumn{3}{|c|}{$2000 / 01$} & \multicolumn{3}{|c|}{$\begin{array}{c}\text { Prel. } \\
2001 \% 2\end{array}$} \\
\hline & $\begin{array}{c}\text { Dis- } \\
\text { bursed }\end{array}$ & $\begin{array}{l}\text { Undis- } \\
\text { bursed }\end{array}$ & Total & $\begin{array}{l}\text { Dis- } \\
\text { bursed }\end{array}$ & $\begin{array}{l}\text { Undiz- } \\
\text { bursed }\end{array}$ & Total & $\begin{array}{c}\text { Dis- } \\
\text { bursed }\end{array}$ & $\begin{array}{l}\text { Undis- } \\
\text { bursed }\end{array}$ & Total & $\begin{array}{l}\text { Dis- } \\
\text { bursed }\end{array}$ & $\begin{array}{l}\text { Undis- } \\
\text { bursed }\end{array}$ & Totn] & $\begin{array}{c}\text { Dis- } \\
\text { bursed }\end{array}$ & $\begin{array}{l}\text { Undis- } \\
\text { bursed }\end{array}$ & Total \\
\hline $\begin{array}{l}\text { All Official Creditors } \\
\text { Consortium }\end{array}$ & $\begin{array}{l}22,844 \\
20,956\end{array}$ & $\begin{array}{l}6,164 \\
5,882\end{array}$ & $\begin{array}{l}29,008 \\
26,838\end{array}$ & $\begin{array}{l}25,423 \\
23,281\end{array}$ & $\begin{array}{l}4,762 \\
4,521\end{array}$ & $\begin{array}{l}30,185 \\
27,802\end{array}$ & $\begin{array}{l}25,359 \\
23,165\end{array}$ & $\begin{array}{l}4,314 \\
4,046\end{array}$ & $\begin{array}{l}29,573 \\
27,211\end{array}$ & $\begin{array}{l}25,606 \\
24,009\end{array}$ & $\begin{array}{l}3,017 \\
2,746\end{array}$ & $\begin{array}{l}28,623 \\
26,755\end{array}$ & $\begin{array}{l}27,275 \\
25,765\end{array}$ & $\begin{array}{l}3,864 \\
3,124\end{array}$ & $\begin{array}{l}31,139 \\
28,889\end{array}$ \\
\hline Bilateral & 9,120 & 1,936 & 11,056 & 10,565 & 1,866 & 12,431 & 11,064 & 1,651 & 12,715 & 10,754 & 830 & 11,584 & 11,502 & 651 & 12,153 \\
\hline Belgium & 40 & 16 & 56 & 47 & 41 & 88 & 59 & 30 & B8 & 40 & 9 & 49 & 43 & 5 & $4 B$ \\
\hline Canada & 344 & 0 & 344 & 376 & 0 & 376 & 362 & 0 & 362 & 344 & 0 & 344 & 343 & 0 & 343 \\
\hline France & 1,157 & 236 & 1,393 & 1,231 & 204 & 1,435 & 1,276 & 108 & 1,384 & 1,010 & 38 & 1,048 & 1,062 & 37 & 1,099 \\
\hline Germany & 1,211 & 341 & 1,552 & 1,255 & 294 & 1,549 & 1,280 & 222 & 1,503 & 1,068 & 142 & 1,210 & 1,147 & 115 & 1,262 \\
\hline Italy & 200 & & 200 & 195 & 0 & 195 & 205 & 0 & 205 & 180 & 0 & 180 & 181 & 0 & 181 \\
\hline Japan & 3,156 & 1,229 & 4,385 & 4,425 & 1,254 & 5,679 & 4,827 & 1,019 & 5,846 & 5,101 & 612 & $\$ .713$ & 5,422 & 478 & 5,900 \\
\hline Netherlands & 125 & 0 & 125 & 114 & 10 & 124 & 115 & 10 & 125 & 78 & 10 & 88 & 90 & 8 & 98 \\
\hline Norway & 26 & 2 & 28 & 28 & 22 & 50 & 44 & 6 & 50 & 50 & 0 & 50 & 50 & 0 & 50 \\
\hline Swoden & 97 & 10 & 107 & 104 & 6 & 110 & 104 & 8 & 112 & 76 & 0 & 76 & 127 & 0 & 127 \\
\hline U.K. & 12 & 37 & 49 & 85 & 6 & 91 & 90 & 38 & 128 & 85 & 19 & 104 & 97 & 8 & 105 \\
\hline United States & 2,752 & 65 & 2,817 & 2,705 & 29 & 2,734 & 2,702 & 210 & 2,912 & 2,722 & 0 & 2,722 & 2,940 & 0 & 2,940 \\
\hline Multilateral & 11,836 & 3.946 & 15,782 & 12,716 & 2,655 & 15,371 & 12,101 & 2,395 & 14,496 & 13,255 & 1,916 & 15,171 & 14,263 & 2,473 & 16,736 \\
\hline $\mathrm{ADB}$ & 5,179 & 1,905 & 7,084 & 5,528 & 1,192 & 6,720 & $\$, 710$ & 1,252 & 6,962 & 6,043 & 1,252 & 7,295 & 6,151 & 1,889 & 8,040 \\
\hline IBRD & 2,924 & 670 & 3,594 & 3,263 & 428 & 3,691 & 2,335 & 310 & 2,645 & 2,905 & 127 & 3,032 & 2,820 & 75 & 2,895 \\
\hline IDA & 3,551 & 1,142 & 4,693 & 3,733 & 855 & 4,588 & 3,857 & 729 & $4,5: 36$ & 4,123 & 439 & 4,562 & 5,097 & 406 & 5,503 \\
\hline IFAD & 124 & 125 & 249 & 128 & 126 & 254 & 128 & 63 & 190 & 112 & 67 & 179 & 117 & 76 & 193 \\
\hline NORDIC & 33 & 15 & 48 & 47 & 7 & 54 & 50 & 2 & 52 & 37 & 0 & 37 & 36 & 0 & 36 \\
\hline Bahrain & 25 & 0 & 25 & 17 & 0 & 17 & 18 & 0 & 18 & 30 & 0 & 30 & 30 & 0 & 30 \\
\hline E. I. Bank & 0 & 89 & 89 & 0 & 47 & 47 & $\mathfrak{3}$ & 40 & 42 & $s$ & 31 & 36 & 12 & 27 & 39 \\
\hline Non-Consortuim & 1,711 & 222 & 1,933 & 1,968 & 148 & 2,116 & 2,043 & 180 & 2,223 & 1,512 & 160 & 1,672 & 1,447 & 616 & 2,063 \\
\hline OPEC Countries & 182 & 86 & 268 & 243 & 111 & 35.4 & 253 & 152 & 405 & 244 & 141 & 385 & 255 & 360 & 615 \\
\hline UAE & 60 & 0 & 60 & 56 & 0 & 56 & 58 & 0 & 58 & 65 & 0 & 65 & 66 & 265 & 331 \\
\hline Turkey & 0 & 0 & 0 & 48 & 0 & 48 & 58 & 42 & 100 & 58 & 42 & 100 & 58 & 0 & 58 \\
\hline Kuwait & 74 & 49 & 123 & 78 & 76 & 154 & 80 & 76 & 156 & 65 & 75 & 140 & 68 & 76 & 144 \\
\hline Libya & 13 & 0 & 13 & 13 & o & 13 & 13 & 0 & 13 & 3 & 0 & 3 & 8 & 0 & 8 \\
\hline Oman & 1 & 0 & 1 & 9 & 0 & 9 & 4 & 0 & 4 & 3 & 0 & 3 & 0 & 0 & 0 \\
\hline Saudi Arabia & 34 & 37 & 71 & 39 & 35 & 74 & 40 & 35 & 75 & 50 & 24 & 74 & 55 & 19 & 74 \\
\hline Other Countries & 1,529 & 136 & 1,665 & 1,725 & 37 & 1,762 & 1,790 & 28 & 1,818 & 1,268 & 19 & 1,287 & 1,192 & 256 & 1,448 \\
\hline Australia & 417 & 0 & 417 & 493 & 0 & 493 & 486 & 0 & 486 & 0 & 0 & 0 & 0 & 0 & 0 \\
\hline Austria & 344 & 0 & 344 & 381 & 0 & 381 & 382 & 0 & 382 & 31 & 0 & 31 & 33 & 16 & 49 \\
\hline Singapore & 3 & 0 & 3 & 5 & 0 & 6 & 2 & 0 & 2 & 0 & 0 & 0 & 0 & 0 & 0 \\
\hline China & 369 & 32 & 401 & 397 & 32 & 429 & 409 & 28 & 437 & 172 & 19 & 191 & 128 & 238 & 366 \\
\hline Czechosiovakia & 13 & 0 & 13 & 14 & 0 & 14 & 15 & 0 & 15 & 5 & 0 & 5 & 2 & 0 & 2 \\
\hline Denmark & 20 & 0 & 20 & 19 & 0 & 19 & 19 & 0 & 19 & 15 & 0 & 15 & 16 & 0 & 16 \\
\hline Finland & 6 & 0 & 6 & 6 & 0 & 6 & 6 & 0 & 6 & 7 & 0 & 7 & 6 & 0 & 6 \\
\hline Kotea & 21 & 3 & 24 & 65 & 0 & 65 & 106 & 0 & 106 & 775 & 0 & 775 & 738 & 0 & 738 \\
\hline Spain & 58 & 5 & 63 & 61 & 4 & 65 & 68 & 0 & 68 & 78 & 0 & 78 & 76 & 2 & 78 \\
\hline Switzerland & 101 & 1 & 102 & 102 & l & 103 & 105 & 0 & 105 & 63 & 0 & 63 & 68 & 0 & 68 \\
\hline Russia & 177 & 95 & 272 & 181 & 0 & 181 & 192 & 0 & 192 & 122 & 0 & 122 & 125 & 0 & 125 \\
\hline OPEC Fund & 46 & 29 & 75 & 40 & 26 & 66 & 33 & 24 & 57 & 30 & 28 & 58 & 26 & 22 & 48 \\
\hline Islamic Dev. Bank & 131 & 31 & 162 & 134 & 67 & 201 & 118 & 64 & 181 & 55 & 83 & 138 & 37 & 102 & 139 \\
\hline
\end{tabular}

